\title{
A Geoarcheological Survey of the Proposed Plainview Hike and Bike Trail, Hale County, Texas
}

Charles D. Frederick

Jennifer L. Thompson

Karla J. Córdova

Follow this and additional works at: https://scholarworks.sfasu.edu/ita

Part of the American Material Culture Commons, Archaeological Anthropology Commons, Environmental Studies Commons, Other American Studies Commons, Other Arts and Humanities Commons, Other History of Art, Architecture, and Archaeology Commons, and the United States History Commons

Tell us how this article helped you.

This Article is brought to you for free and open access by the Center for Regional Heritage Research at SFA ScholarWorks. It has been accepted for inclusion in Index of Texas Archaeology: Open Access Gray Literature from the Lone Star State by an authorized editor of SFA ScholarWorks. For more information, please contact cdsscholarworks@sfasu.edu. 


\section{A Geoarcheological Survey of the Proposed Plainview Hike and Bike Trail, Hale County, Texas}

\section{Licensing Statement}

This is a work produced for the Texas Department of Transportation (TxDOT) by the report producer. TxDOT and the report producer jointly own all rights, title, and interest in and to all intellectual property developed under TXDOT's contract with the report producer. The report may be cited and brief passages from this publication may be reproduced without permission provided that credit is given to both TXDOT and the report producer. Permission to reprint an entire chapter, section, figures or tables must be obtained in advance from either the Supervisor of the Archeological Studies Branch, Environmental Affairs Division, Texas Department of Transportation, 125 East 11th Street, Austin, Texas, 78701 or from the report producer. 


\section{A Geoarcheological Survey of the Proposed Plainview Hike and Bike Trail, Hale County, Texas}

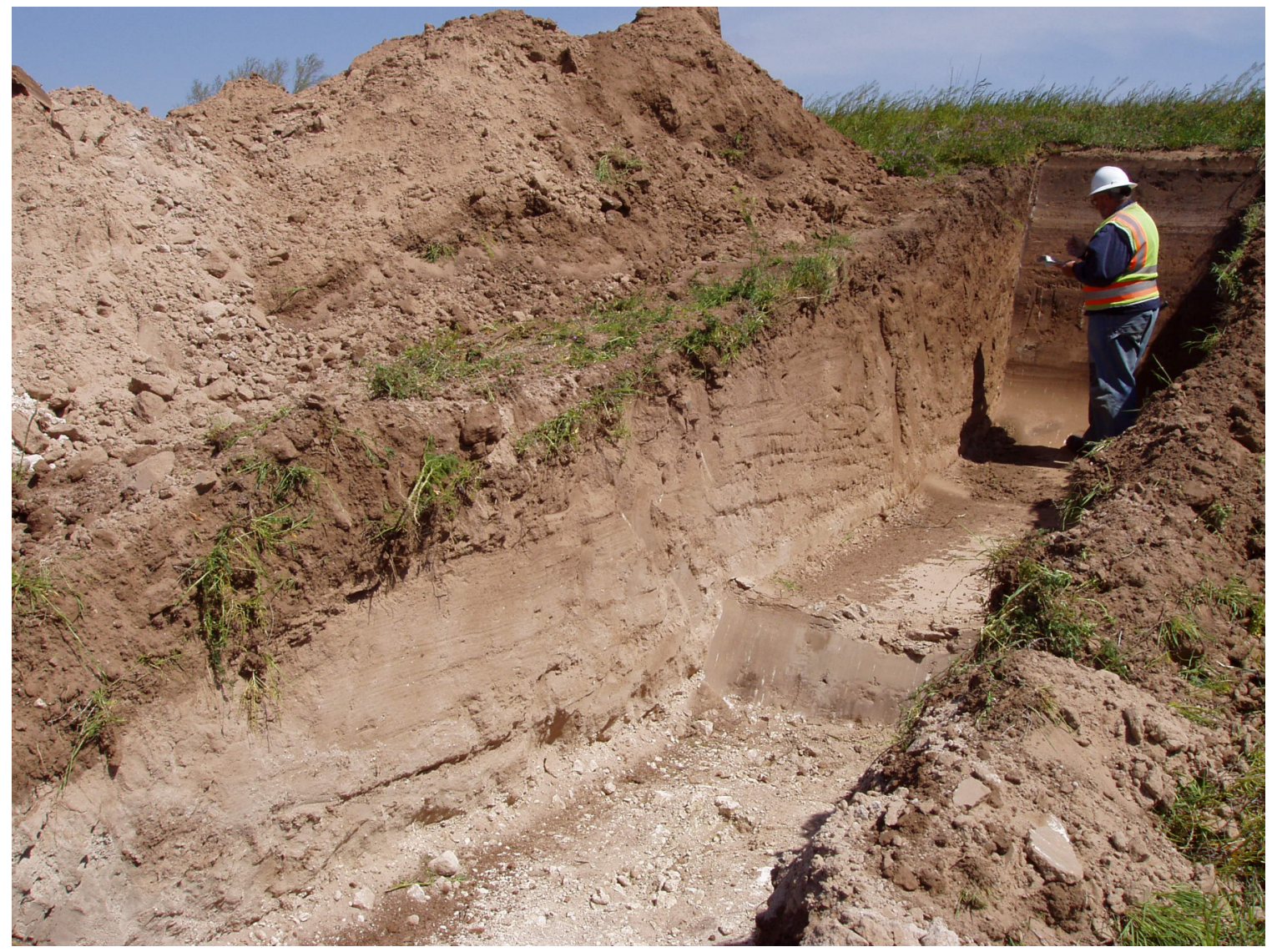

by

Charles D. Frederick, Jennifer L. Thompson and Karla J. Córdova

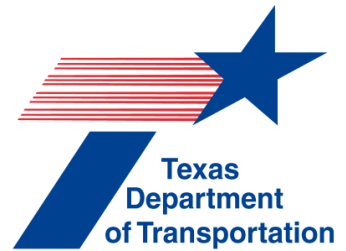

Prepared for:

Environmental Affairs Division Texas Department of Transportation Austin, Texas

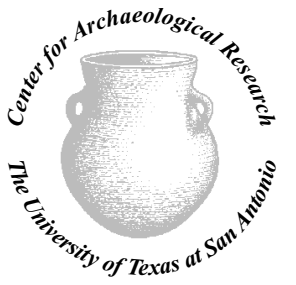

Prepared by:

Center for Archaeological Research The University of Texas at San Antonio Archaeological Report, No. 396 


\section{A Geoarcheological Survey of the Proposed Plainview Hike and Bike Trail, Hale County, Texas}

by

Charles D. Frederick, Jennifer L. Thompson, and Karla J. Córdova

Texas Antiquities Committee Permit No. 3707

Principal Investigators

Dr. Steven A. Tomka and Dr. Raymond P. Mauldin

Work Authorization No. 57501 SA005

Contract No. 575XXSA005

CSJ No. 0905-12-018

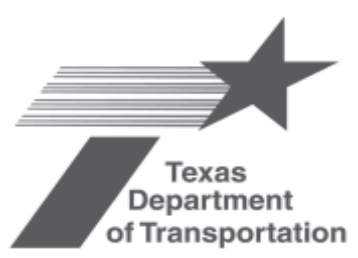

Prepared for:

Environmental Affairs Division

Texas Department of Transportation

Austin, Texas

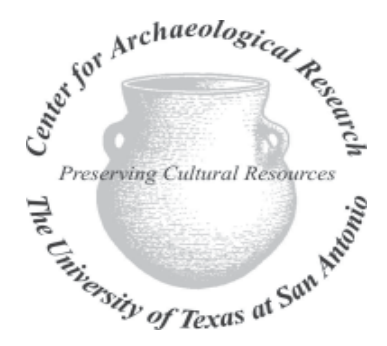

Prepared by:

Center for Archaeological Research

The University of Texas at San Antonio

Archaeological Report No. 396 



\begin{abstract}
In March of 2005, the Texas Department of Transportation issued work authorization \#575-01-SA005 to the Center for Archaeological Research (CAR) at the University of Texas at San Antonio to conduct a survey of areas affected by proposed improvements to the Plainview hike and bike trail in southern Plainview, Hale County, Texas. The survey was conduced under Texas Antiquities Permit \#3707 between March 31 and April 7, 2005. Steve Tomka and Raymond Mauldin served as Principal Investigators.
\end{abstract}

Trail construction included 2.0 miles of additional construction and 1.3 miles of improvements to existing trails. The Right-ofWay is 50 feet and extends from one to three feet below ground surface. Archeological services included a pedestrian survey, excavation of fifty-five auger tests placed no more than $100 \mathrm{~m}$ apart, and twenty-one Gradall trenches. Two of these trenches exposed the stratigraphy of Running Water Draw near the Plainview Site, 41HA1. Bulk samples were collected for OSL dating, diatoms analysis, and lithologic analysis for further examination of the age and stratigraphic context of the Plainview Site, which is a State Archeological Landmark, a National Landmark, and a National Register of Historic Places property. Site 41HA12 was re-examined with 10 mechanical auger tests and 1 trench, which found only recent alluvial and cultural deposition. No additional archeological sites were recorded. This report includes descriptions of the fieldwork, results of the special analyses performed on bulk sediment samples collected, and a discussion of the geomorphology of Running Water Draw with specific focus on the results from trenches excavated near the Plainview Site.

The single artifact and all documents and photographs generated from this project are curated at the Center for Archaeological Research at The University of Texas at San Antonio. 


\section{Table of Contents:}

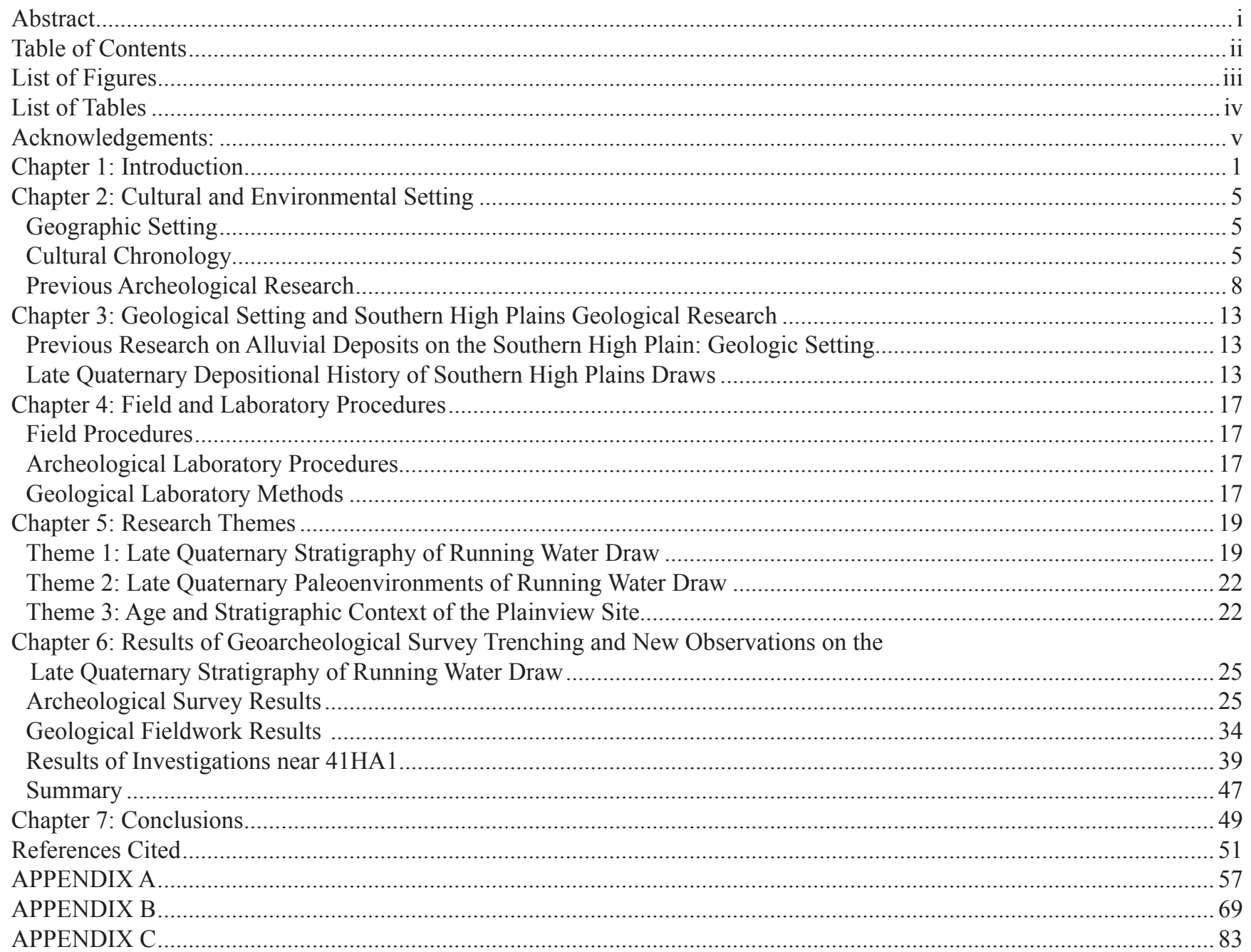




\section{List of Figures:}

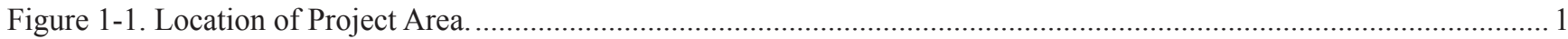

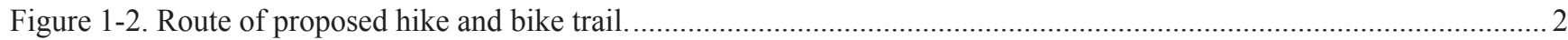

Figure 2-1. Location of 41HA12 site datum and Low-Water Crossing \#5 .............................................................. 9

Figure 2-2. Identified locations of the Plainview Site from previous excavations............................................................... 11

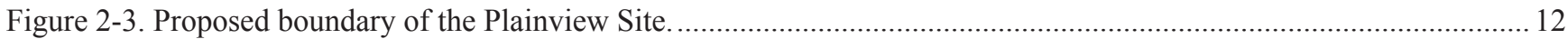

Figure 3-1. This is a copy of three of figures from Holliday's publications (1985, and 1990)

showing the location of the borrow pits he has documented in proximity to the Plainview Site, and his interpretations of the late Quaternary stratigraphy of Running Water Draw exposed within these excavations.... 15

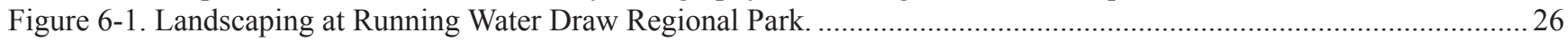

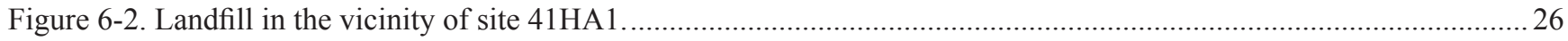

Figure 6-3. Disturbed areas along proposed hike and bike trail between Quincy and Ennis Streets..................................2 27

Figure 6-4a. Locations of auger tests and Gradall trenches along eastern end of project ROW from

Cedar Street to S. Columbia Street.

Figure 6-4b. Locations of auger tests and Gradall trenches along project ROW between Columbia Street and Joliet Street.

Figure 6-4c. Locations of auger tests and Gradall trenches along project ROW between Joliet Street and Quincy Street.

Figure 6-4d. Locations of auger tests and Gradall trenches along western end of project ROW

(in Running Water Draw Regional Park) between Joliet Street and Quincy Street. .........................................................31

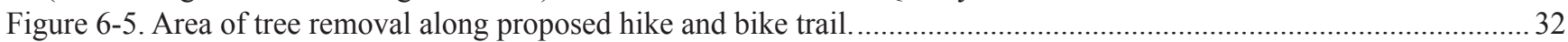

Figure 6-6. Map showing location of Scallorn point recovered west of site datum for 41HA12 _................................... 33

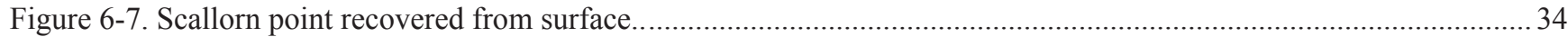

Figure 6-8. Cartoon sketch illustrating the stratigraphy observed in Running Water Draw during this project...................... 35

Figure 6-9. Photograph of the north wall of Gradall Trench 4, annotated to show the location of major stratigraphic features (e.g. buried soils), Holliday's stratigraphic units, and the results of radiocarbon dates

obtained for bone (the top date) and bulk sediment (the lower two radiocarbon dates).

Figure 6-10. Illustration of the deposits exposed on the north wall of Gradall Trench 11.................................................. 38

Figure 6-11. Line drawing of the stratigraphy revealed by the north wall of Gradall Trench 10 ......................................39

Figure 6-12. Field sketch of the lateral distribution of the deposits exposed within Gradall Trench 20. .............................. 40

Figure 6-13. Drawing of the stratigraphy revealed by Gradall Trench 20 that was excavated

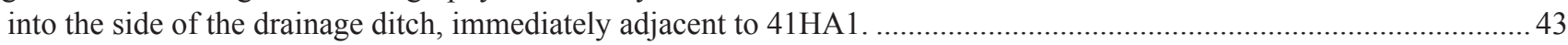

Figure 6-14. A revised version of Holliday (1985, Figure 7; see Figure 3-1) ..................................................................... 46 


\section{List of Tables:}

Table 3-1. Stratigraphic Framework for Running Water Draw, from Holliday (1995) .................................................... 16

Table 5-1. List of Trenches, the Stratigraphic Units Exposed, and Samples Collected during Fieldwork ........................... 20

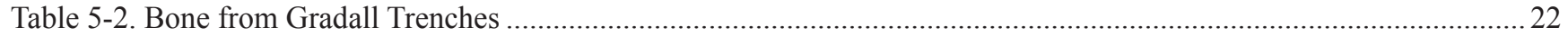

Table 6-1. Location of Gradall Trenches Excavated during Fieldwork ............................................................................... 33

Table 6-2. List of Trenches Where Different Lithostratigraphic Units were Observed .......................................................... 35

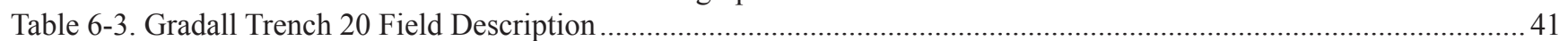

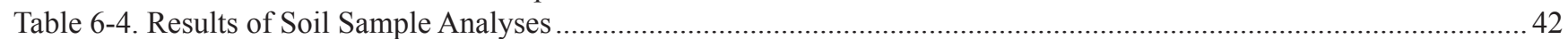




\section{Acknowledgements:}

The successful completion of this project would not have been possible without the assistance of many people. Special thanks to Texas Department of Transportation staff, especially Davis Melton, David Alexander, Karen Bradshaw, Caroline Hinkelman, and Joe Treviño, for providing us with all necessary information and assistance. Thanks also go to Derald Shadix and James Edwards, TxDOT Gradall and Bobcat operators, for a wonderful job. Thanks to Randy Woods, Frank Peña, John Berry, and Tim Salazar with the City of Plainview who so graciously provided insightful information and assistance during the excavation process. Our gratitude also goes to G. R. Dennis Price and Barbara Hickman of TxDOT for a fantastic job during the Jicarilla Apache visit. The field crew consisted of Bryant Saner and Leonard Kemp whose hard work is greatly appreciated. Thanks to Bruce Moses and Dr. Raymond Mauldin for field mapping the site. Kristi Ulrich submitted samples for special analyses and made additional research trips to the Llano Estacado Museum. Bruce Moses and Rick Young produced the graphics for this report and Jennifer Thompson served as technical editor. Also, thanks to Dr. Steve Tomka, CAR Director, and Dr. Raymond Mauldin, CAR Assistant Director, for their assistance and guidance throughout all the stages of this project.

We learned with great sadness the passing of Eddie Guffee earlier this year. Our deepest gratitude and respect go to Eddie Guffee who took time during this investigation to return to the Plainview Site and offered notes, maps, photographs and his first-hand knowledge of the site. We dedicate this volume to him.

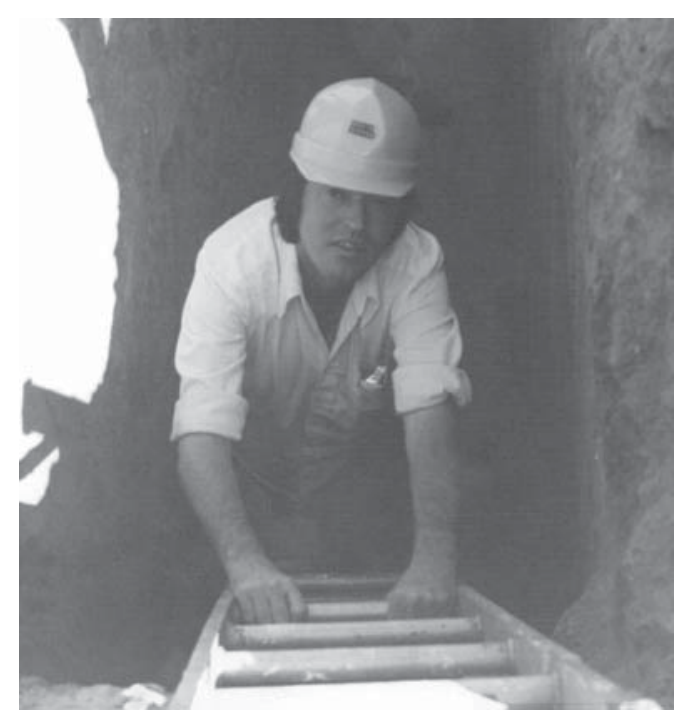

Eddie Guffee at the Plainview Site 



\section{Chapter 1: Introduction}

In March of 2005, the Texas Department of Transportation issued work authorization \#57051SA005 to the Center for Archaeological Research (CAR) at the University of Texas at San Antonio to conduct a survey of areas that would be affected by proposed improvements to the Plainview hike and bike trail in southern Plainview, Hale County, Texas (Figure 1-1). The survey was conducted under Texas Antiquities Permit \#3707. Steve Tomka and Raymond Mauldin served as Principal Investigators. The survey occurred between March 31 and April 7, 2005. It was designed to identify any significant or potentially significant archeological sites or deposits within the proposed trail right-of-way (ROW) that would be potentially affected by trail modifications and construction of new trail segments. On June 2 and 3, 2005, CAR archeologists made an additional visit. At this time, a 13 meter by 2.3 -meter Gradall trench (GT) was excavated within the hike and bike trail ROW in the proposed low water crossing location (C-4).
The hike and bike trail improvements include 2.0 miles of new trail construction and 1.3 miles of improvements to the existing trail. The trail begins in Running Water Draw Regional Park and extends east to Broadway Park along 4th Street and the channel of Running Water Draw. A short segment of the trail extends north connecting to Milwaukee Street (Figure $1-2)$. The trail's ROW is 50 feet $(15.24 \mathrm{~m})$ wide and includes a variable Area of Potential Effect (APE) including various widths of sidewalk, curb and gutter, asphalt lane and gravel roadway. The APE also includes seven water crossings of Running Water Draw and the removal of nine trees along the west and east sides of Joliet Street that will result in subsurface impacts. Based on the information provided by Davis Melton (Lubbock Environmental Coordinator) to Dr. Steve Tomka, the proposed depth of impact for the sidewalk and curb and gutter construction was between one and three feet below current ground surface (D. Melton, personal communications October 8, 2004). Only one previously recorded site, 41HA12

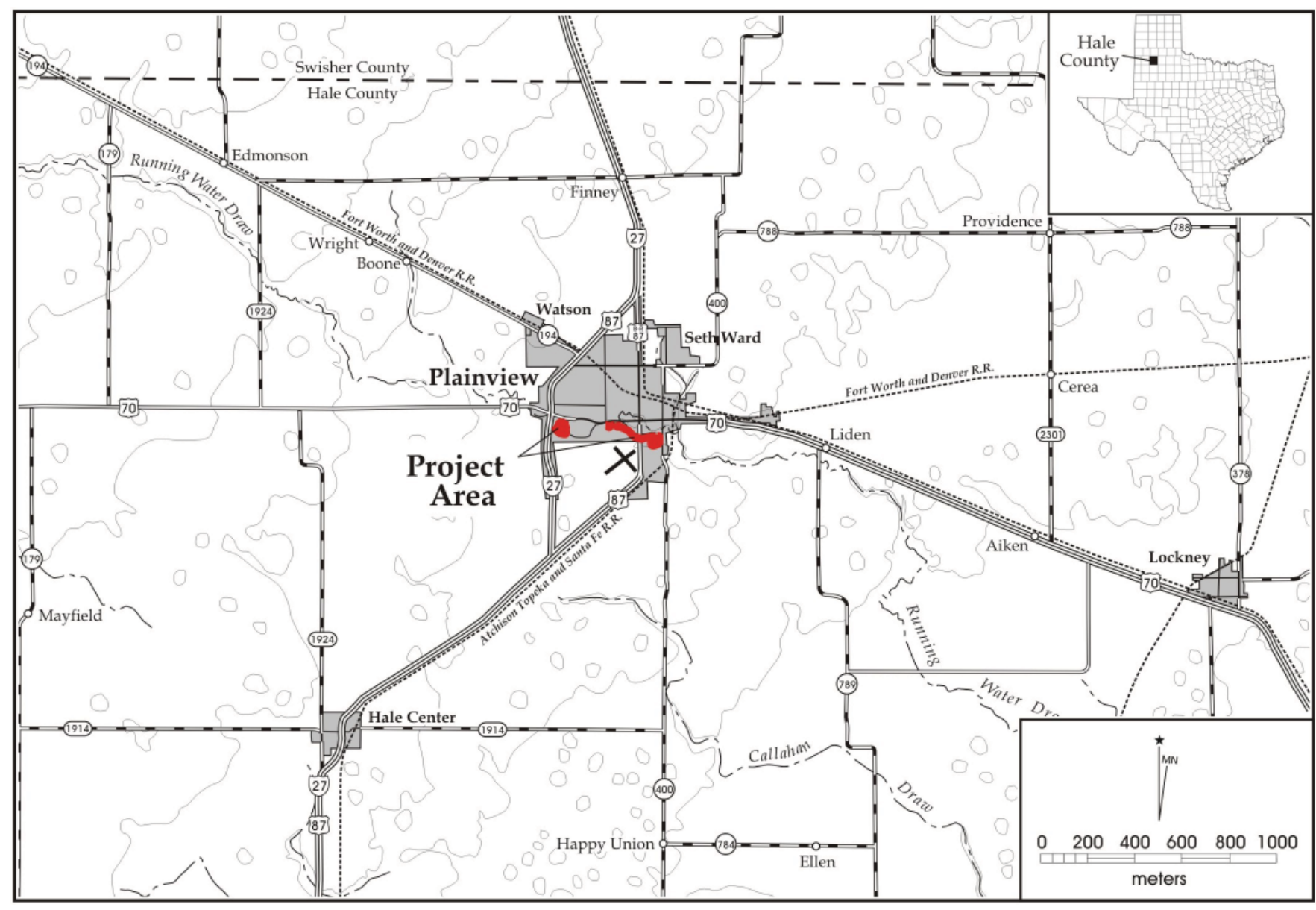

Figure 1-1. Location of Project Area. 


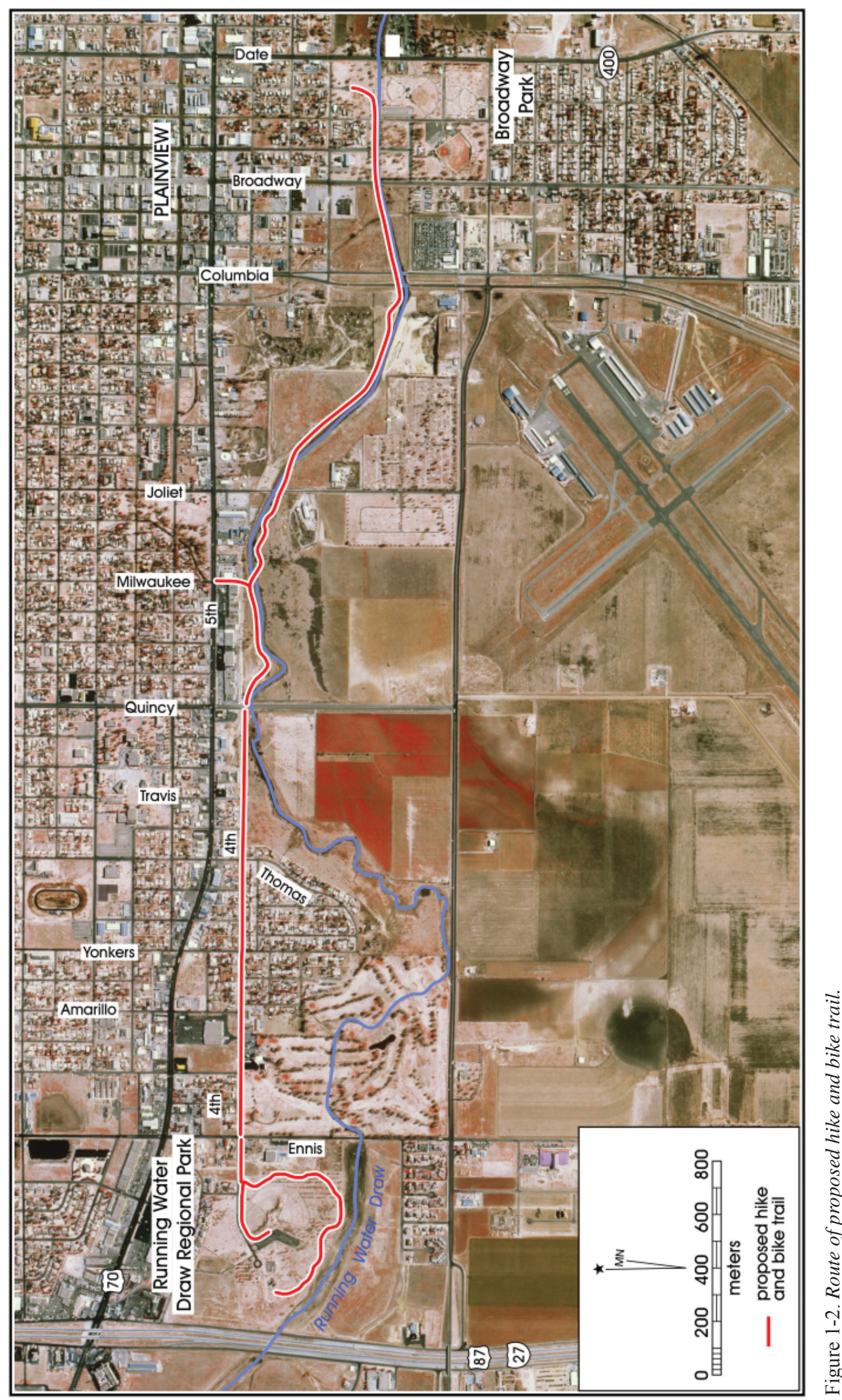


lies within the APE. Reconstructions of the site boundaries of the Plainview Site, 41HA1, show the APE just to the north but not crossing the site boundary. The Plainview Site is a National Register of Historic Places property and National Historic Landmark so careful consideration was given to the proximity of the site to the APE.

No new archeological sites were recorded and only one clearly cultural artifact was recovered during the entire survey. Therefore, the results of CAR's investigation were largely geomorphological as the work involved the examination of backhoe trenches at increments along Running Water Draw through the City of Plainview. Two of the trenches were near to $41 \mathrm{HA} 1$. The observations collected from these trenches are relevant to three themes outlined in the research design: 1) the late Quaternary stratigraphy of Running Water Draw, 2) the late Quaternary paleoenvironments of Running Water Draw, and 3) the age and stratigraphic context of the Plainview Site. Analyses performed associated with these research themes include C14 and OSL dating of bulk samples and bone fragments and analysis of diatom samples from Running Water Draw.

This report outlines the previous archeological and geological research conducted in the area in Chapters 2 and 3, the field and lab methods used during the project in Chapter 4, the research themes in Chapter 5, the results of the fieldwork in Chapter 6, the conclusions and recommendations in Chapter 7 , and the results of special analyses described in the research design in the Appendixes. 



\section{Chapter 2: Cultural and Environmental Setting}

Paleo-environmental studies, Paleoindian archeology, and geology have jointly contributed to the natural and cultural history of the Southern High Plains. The information on the environmental and cultural setting in this chapter draw largely from the work of Johnson and Holliday (2004) and Holliday's (1997) geoarcheological study of the Southern High Plains. A focus on the Paleoindian Period is due to available, reliable archeological data and relevance to the known deposits at the Plainview Site in the specific project area.

\section{Geographic Setting}

The project area is located in the Texas Panhandle Plains (Tomka 2004) which falls within the Southern High Plain or Llano Estacado. Holliday suggests that the Llano Estacado is the "most environmentally homogenous region of its size in North America" (Holliday 1997:8). It is a plateau that spans $130,000 \mathrm{~km} 2$ of the southern expanse of the High Plains with 50 to 200 meter high escarpments on three sides (Holliday 1997:9). The Pecos River runs to the west and the Canadian River runs to the north. Tributaries of the Brazos, Red, and Colorado Rivers form the east escarpment of the plateau that separates the Plateau from the Rolling Plains. The southern boundary of the Llano Estacado is less prominent. It gradually merges with the Edwards Plateau, defined by the northernmost outcrops of Edwards Limestone (Holliday 1997:9).

Vegetation of the Llano Estacado is mixed prairie grassland. Prior to Anglo settlement, trees were present only along the bordering escarpments and in canyons. Little native vegetation remains due to modern cultivation on the plateau but the vegetation was likely grassland throughout the Holocene and the vegetation community likely varied from semiarid savannah to semi-arid grassland during the Pleistocene (Holliday 1997).

Altitudes on the Southern Plains range from 1700 to 750 $\mathrm{m}$ sloping downward toward the southeast. Many playas scattered across the plateau contain seasonal lakes. These hold the only available surface water on the Llano Estacado. Sand dune fields are also prominent across the western edge of the plateau and are present on the edges of the playas. Dry river valleys cross the plateau off the rolling Plains from northwest to southeast (Holliday 1997:10).

The Southern High Plains are a great mass of Cenozoic alluvium derived by outwash from the Rocky Mountains to the west (Guffee 1979). The area is bounded on the east by a conspicuous caprock escarpment. The majority of soils in the project area belong to the Mansker-Bippis-Berda association, described as nearly level to sloping calcareous loams and fine sandy loams. A small part of the trail, located in the western end of the project, falls within the Pullman-Olton association. This association is nearly level to gently sloping noncalcareous clay loams and loams. The specific soil types present in the project area are Lofton clay loam; Bippus loam, 1-3\% slopes, Mansker loam, 3-5\% slopes, and Pullman clay loam, 0-1\% slopes (Blakey and Koos 1974).

The project area has been widely affected by urban development in the town of Plainview, especially in the area from Ennis Street to Quincy Street. Vegetation in the study area includes grasses, invader weed species, imported ornamentals, and some mixed mesquite shrub and grassland species (Tomka 2004). The vegetation present in both Running Water Draw Regional Park and Broadway Park is primarily the result of urban landscaping. Most of the project area runs adjacent to the channel of Running Water Draw, which has been channelized nearly the entire length of the project area. This drainage is the uppermost headwater tributary of the Brazos River (Guffee 1979).

\section{Cultural Chronology}

The Southern High Plains has a human history that spans almost 12,000 years and contains some of the most renowned Paleoindian archeological sites in North America. Most sites consist of sulphur-exposed deposits and represent single occupations, but due to the natural history of the area, some buried sites are preserved representing multiple occupations. The most well-documented sites in the Southern High Plains include the Lubbock Lake Site, which has a nearly complete archeological record (Johnson 1987), Clovis (Hester 1972), San Jon (Roberts 1942), Plainview (Sellards et al. 1947), Marks Beach (Honea 1980), and Lake Theo (Harrison and Killen 1978). The cultural chronology of the area is divided into five periods. Paleoindian (11,500 to $8500 \mathrm{BP})$, Archaic (8500 to $2000 \mathrm{BP}$ ), Ceramic (2000 BP to AD 1450), Protohistoric (AD 1450 to 1650), and Historic (AD 1650 to 1950).

\section{Paleoindian (11,500 to 8500 BP)}

The Paleoindian Period began at the end of the Pleistocene and lasted through the early Holocene. Important characteristics 
of the period include an economic focus on hunting with the use of distinctive lanceolate, unnotched dart points. Hunters hunted and scavenged now extinct megafauna across North America like mammoth, mastodon, bison, caribou, camel, horse, and other small species. This period is further divided into temporal subperiods defined by the presence of certain projectile point forms associated with radiocarbon dates. The early Paleoindian subperiod includes Clovis $(11,500$ to $11,000 \mathrm{BP})$ and Folsom $(10,800$ to $10,300 \mathrm{BP})$ cultures and late Paleoindian (10,000 to $8500 \mathrm{BP})$, which includes Plainview and Firstview cultures.

Preceding the early Paleoindian subperiod, the Southern High Plains had a humid, maritime climate with cool summers and mild winters. The savannas had plenty of ponds and streams with trees along the escarpments. During Clovis times, the environment was also cool and moist, with cooler summers and warmer winters than present day. All the draws contained permanent water, and the uplands contained ponds and marshes. Game available to hunter-gatherers included both megafauna and smaller animals, though by the end of the Clovis period, the megafauna were approaching extinction (Holliday 1997:177).

The Clovis period is the oldest known Paleoindian culture and is distinguished by the use of large fluted dart points sometimes found with the remains of megafauna and other extinct Pleistocene species. Three sites that have confirmed intact Clovis components are Blackwater Draw Locality No. 1 (Hester 1972) in New Mexico, the Miami site on the open High Plains (Sellards 1938) in Texas, and Lubbock Lake (Johnson 1987), also in Texas. All include the remains of megafauna. The Clovis site has one of the most extensive occupations of the period and the material culture includes several resharpened Clovis points reused for butchering. The bones analyzed from both the Clovis and Lubbock Lake sites show processing marks, though excavations of the Lubbock Lake Clovis component recovered no lithic tools. The Miami site bones showed no evidence of processing marks but did contain Clovis projectile points associated with mammoth remains (Hughes and Willey 1978:25). Radiocarbon dates from these bone beds cluster around 11,000 BP (Johnson and Holliday 2004:286).

The Clovis-Folsom transition was marked by climate change, widespread extinction of megafauna, continued warming, and greater seasonality. Early in the Folsom period, perennial streams continued to flow in certain draws, but freshwater ponds began to disappear with the decreased flow. By the end of the Folsom occupation, the streams stopped flowing and lakes evolved into muddy marshes. The decrease in water flow was a result of decreased precipitation on the plains during the transition between the Pleistocene and Holocene. Marshes and mixed grasslands dominated by deciduous tress developed (Johnson and Holliday 2004; Holiday 1997:182). The drier climate promoted eolian sand deposits in vegetated areas on uplands. Sand sheets have been noted at various Folsom sites on the Southern High Plains. During the Folsom period, occupants of the Llano Estacado endured a warmer, dryer, and windier, climate than before. (Holiday 1997).

The Folsom tradition hunter-gatherers also used fluted points to hunt big game. Besides the Folsom type-site in New Mexico, well-documented Folsom sites on the Llano Estacado include the Clovis site and Lubbock Lake. Excavations at the Folsom site were the first to show an association with humans and extinct fauna in North America. Several Folsom projectile points were found in association with the remains of Bison antiquus in a playa. Both the Clovis and Lubbock Lake sites have evidence of a series of bison kills at each locale. At Clovis, the herds were killed and butchered around marshy ponds in several episodes between 10,490 and 10,170 BP (Hester 1972). The Lubbock Lake bison kills also occurred around ponds and were butchered between 10,800 and 10,300 BP (Johnson and Holliday 2004). Both expedient and formal tools were recovered at Lubbock Lake. Numerous other Folsom sites have been recorded from surface finds, some in proper stratigraphic context (Hester 1975).

The post-Folsom, Late Paleoindian occupations are associated with unfluted, lanceolate projectile points like Plainview and Firstview, but also include constricted stem styles. The Plainview projectile point style was the first unfluted Paleoindian point described (Krieger 1947). The environment continued warming and drying and seasonal fluctuations in temperature were relatively pronounced. Plainview occupations on the Llano Estacado include the Plainview type-site, Lubbock Lake, Williamson, and Ryan. Nearby sites off the plateau include Bonfire Shelter and Lake Theo.

At the Plainview Site, a thick bone bed was discovered in a stream channel in Running Water Draw. Over a hundred bison were recovered and thought to be killed in two episodes, one in spring and the other in early fall (Johnson and Holliday 1997). No bone butchering tools were recognized though many Plainview projectile points were recovered.

The Lake Theo site also contains a Plainview occupation above the Folsom strata. The vertical distribution of lithic artifacts suggests the site was revisited repeatedly during late Paleoindian Plainview times (Harrison and Killen 1978). Ryan's site contained Plainview projectiles, large bifaces, and large flakes within a disturbed plow zone. The Plainview 
occupation at Lubbock Lake showed continued bison kills near marshy ponds with distinct bone concentrations, resharpened and reused butchering tools (Johnson and Holliday 1997). The Mark's Beach site contained Plainview aged disarticulated bison remains but had no clear cultural component (Honea 1980).

The Clovis site, San Jon, and Lubbock Lake all have Firstview components. Three bison kill and butchering episodes were uncovered at the Clovis site from 10,500 to 8500 BP (Haynes 1995). Reworked Firstview forms were recovered elsewhere on site with additional bison remains and flaked tools. The San Jon site includes a bone bed at the edge of a playa with at least five articulate bison and humate dating it to $8360 \mathrm{BP}$ (Hill et al. 1995). The Lubbock Lake Firstview occupation also includes a bone bed thought to be a bison kill and butchering site on the edge of a pond. Bones continued to be found in groups as in the Plainview occupation. Few processing marks were identified on the bone and there was limited evidence of bone tool manufacturing and use unlike within the Plainview component. Flake tools and reworked Firstview points were reused as butchering tools. This occupation at Lubbock Lake was dated to $8600 \mathrm{BP}$.

\section{Archaic Period (8500 to 2000 BP)}

Less is known about the Archaic than other cultural periods across the Southern High Plains. Though many Archaic components have been recorded, few have been excavated perhaps because the geologic conditions were not conducive to site preservation during the Archaic (Johnson and Holliday 1986). Lubbock Lake has the most complete, well-stratified Archaic archeological record of any excavated site on the Southern High Plain. Subdivision of the period coincide with environmental changes from the warming trend in the early Holocene during the early Archaic, to the xeric conditions of the mid-Holocene (Holiday 1997)

During the Early Archaic subperiod, climate became increasingly arid and sandy sediments began accumulating in draws and contributed to dune formation on the uplands. Few sites dating to this period have been excavated so little is known about the earliest subperiod of the Archaic. The Lubbock Lake site and San Jon are two Early Archaic sites that have seen some level of excavation. These excavations confirm a continued subsistence focus on big game hunting (Johnson and Holliday 2004:290). At Lubbock Lake, a bone bed with at least three bison was uncovered. No temporally diagnostic lithics were found within the feature (Holliday 1997:23).

The hot and dry Altithermal occurred at the beginning of the Middle Archaic. Surface water and vegetation decreased and contributing to the formation of a desert grassland. A few sites from the Middle Archaic have been excavated. Three of these are well sites: Blackwater Draw \#1 (Evans 1951), Mustang Springs (Meltzer 1991), and Marks Beach (Honea 1980). At the Lubbock Lake site, several activity areas were identified including bison kill and butchering areas and an earth oven dating to 4800 BP (Johnson and Holliday 1986). Middle Archaic projectile points excavated from Lubbock Lake include Trinity, Ellis and Bulverde types (Holliday 1987:23). Mustang Springs geoarcheological studies uncovered a well field that could indicate an adaptation of Archaic groups to the dry conditions of the Altithermal (Meltzer 1991).

By the end of the Middle Archaic, temperatures on the Llano Estacado began to cool and rainfall increased. With the renewed moisture, trees returned to the draws and marshlands again dotted the valleys. Playas also held seasonal surface water on the uplands (Johnson and Holliday 2004).

The Late Archaic climate was most similar to the present day climate in the area. Late Archaic deposits are not commonly found in situ though the Late Archaic is the best represented on the Southern High Plains (Holliday 1987). At Chalk Hollow (Lintz 2002), three camping localities were identified between 2000-4000 BP and containing corner and side-notched projectile points. At San Jon, the only bison kill recorded for this period on the Southern High Plains was excavated (Johnson and Holliday 2004:292). Seven bison were butchered and killed here. Finally, at Lubbock Lake, nine occupations were identified along with burned caliche from scattered hearths, broken tools, and concentrations of debitage.

\section{Ceramic Period (2000 to 500 BP)}

The transition from Archaic lifeways included use of ceramic and bow and arrow technologies perhaps in addition to the continued use of darts. The best-recorded sites from this period have mixed dart and arrow points and pottery. The earliest dates recorded for sites in the region that have arrow points and pottery fall between $1740 \mathrm{BP}$ and $1830 \mathrm{BP}$ (Johnson and Holliday 2004:292). Scallorn arrow points and coarse-tempered cord-marked pottery date to the Ceramic Period but are not well dated in the region (Johnson and Holliday 2004:292). A midden at Chalk Hollow (Lintz 2002) and certain occupations at Lake Creek (J. Hughes 1962) and Borger Bridge (Hughes and Willey 1978) contained Ceramic Period artifacts. The Lubbock Lake Ceramic Period component contains a hearth feature, bison remains, a Scallorn point, a bone bead, and debitage thought to be representative of a campsite (Kelley 1974). Scallorn and Deadman's points were also recovered from a campsite (41GR291) in Justiceburg Reservoir (Boyd et al. 1990). 
The late Ceramic Period (1000-500 BP) includes mixed Puebloan Mogollon trade ceramics with Plains lithic tools. Most sites with late Ceramic Period artifacts are not well stratified though many sites have been recorded (Johnson and Holliday 1995). Some of the sites in better context include Jim Arnold (Tunnell 1964) and Floydada Country Club (Word 1991). Lubbock Lake also has processing stations in good context that date to the late Ceramic Period but do not have recorded ceramics.

\section{Protohistoric Period (AD 1450 to 1650)}

The Protohistoric Period covers the time prior to European settlement of the area but after first contact. Archeologically, Garza arrow point types sometimes represent this component. Most of the recorded sites dating to the Protohistoric Period in the region lack good context though there are many Protohistoric sites. The Lubbock Lake site shows evidence of repeated use and Garza projectile points with radiocarbon dates between 500 and 300 BP (Holliday et al. 1983, 1985). Living surfaces with hearths and large game processing were also recorded. Other Garza components were excavated from 41LU26 and 41LU35 (Johnson and Holliday 1997). Less stratified sites with Garza components include the Floydada Country Club, the Montgomery Site, and 41CB27.

\section{Historic Period (AD 1650 to 1950)}

The Historic Period begins with the arrival of European goods and the modern horse to the region. Few historic sites are recorded on the Southern High Plains though the Lubbock Lake Site contains many historic aboriginal occupations with Washita projectile point forms and radiocarbon dates to 300-150 BP (Holiday et al. 1983, 1985). Other historic sites include 41LU35 (Bandy et al. 1981), 41GR484, 41KT53, and 41KT69 (Boyd et al. 1990). Rock art sites have been recorded in Justiceburg Reservoir (Boyd 1992) and Comanche sites have been recorded in MacKenzie Reservoir (Hughes and Willey 1978) and at Lubbock Lake (Ladken 1995).

European historic sites in the region date to the 1880s. The first Europeans were buffalo hunters, sheepherders, traders, settlers, and, members of the US military. Though few historic sites have been excavated, 41GR528, a buffalo hunting camp was tested (Freeman and Boyd 1990). Hispanic sheepherders from New Mexico came to the area in the 1870s and settled in an area near Tascosa (Johnson and Holliday 2004:293). Guffee (1976) tested the Merrell-Taylor village. The Massie site was excavated, as were rock corrals at the Ellis site (Johnson and Holliday 2004). These shepherds returned to New Mexico by the mid-1880s.

Historic sites with European goods excavated along the Canadian River include Adobe Walls (Johnson and Holliday
2004:294) and the Singer Store, a trading post at Lubbock Lake in use from 1883 to 1886 (Hicks 2002). Testing here recovered artifacts related to the store and to buffalo hunting activities (Johnson and Holliday 2004:294). In Justiceburg Reservoir, tested historic sites include a sheepherders camp from the 1880 s, a 1880 s-1920 line camp, several homesteads, ranch headquarters, and town building (Johnson and Holliday 2004:294).

\section{Previous Archeological Research}

The majority of the archeological work on the Southern High Plains has focused on the Paleoindian period (Hoffman and Brooks 1989:176-177). Important Clovis, Folsom, and late Paleoindian sites are located in this general area including Clovis, Miami, Folsom, Lubbock Lake, San Jon, Plainview, and Milnesand sites (Guffee 1979).

Generally, the Southern Plains have been well studied in adjacent states and other areas of Texas (Hofman 1989:4560). Nevertheless, Archaic, Ceramic, and Protohistoric Period adaptations are not well known in this area for various reasons including the scarcity of sites in good stratigraphic context. Four archeological sites located within or near the project area are discussed below.

\section{Archeological Sites Within or Near the Project Area}

The Texas Archeological Sites Atlas (THC 2005) identifies two sites within or immediately adjacent to the project area and two additional sites located near the hike and bike trail ROW. One of these is site 41HA12, located in the eastern part of the project area, west of Broadway Street (Figure 2-1). This site was recorded in 1979 by Dr. Alston Thoms as a prehistoric site of unknown temporal affiliation, containing one heat-fractured rock and several pieces of a coal-like material and charcoal flecks in one auger test (THC 2005). No site boundaries were defined but a 1-x-1-m unit was excavated around one auger test. The cultural material came from 12-14 $\mathrm{cm}$ below surface. Thoms suggested that the burned material was deposited during a flood episode.

Sites 41HA4 and 41HA5 are located south of the project area near to the hike and bike trail's ROW. Both sites are located along the channel of Running Water Draw and were found in association with prairie dog burrows suggesting the possibility of buried deposits. Site 41HA4 is $400 \mathrm{~m}$ south of the proposed location of the hike and bike trail corridor along 4th street. Site $41 \mathrm{HA} 4$ was reported as a 250 -m-by250-m lithic scatter likely dating to the Ceramic Period and containing Texocas, Alibatres, and Edwards chert lithics, 


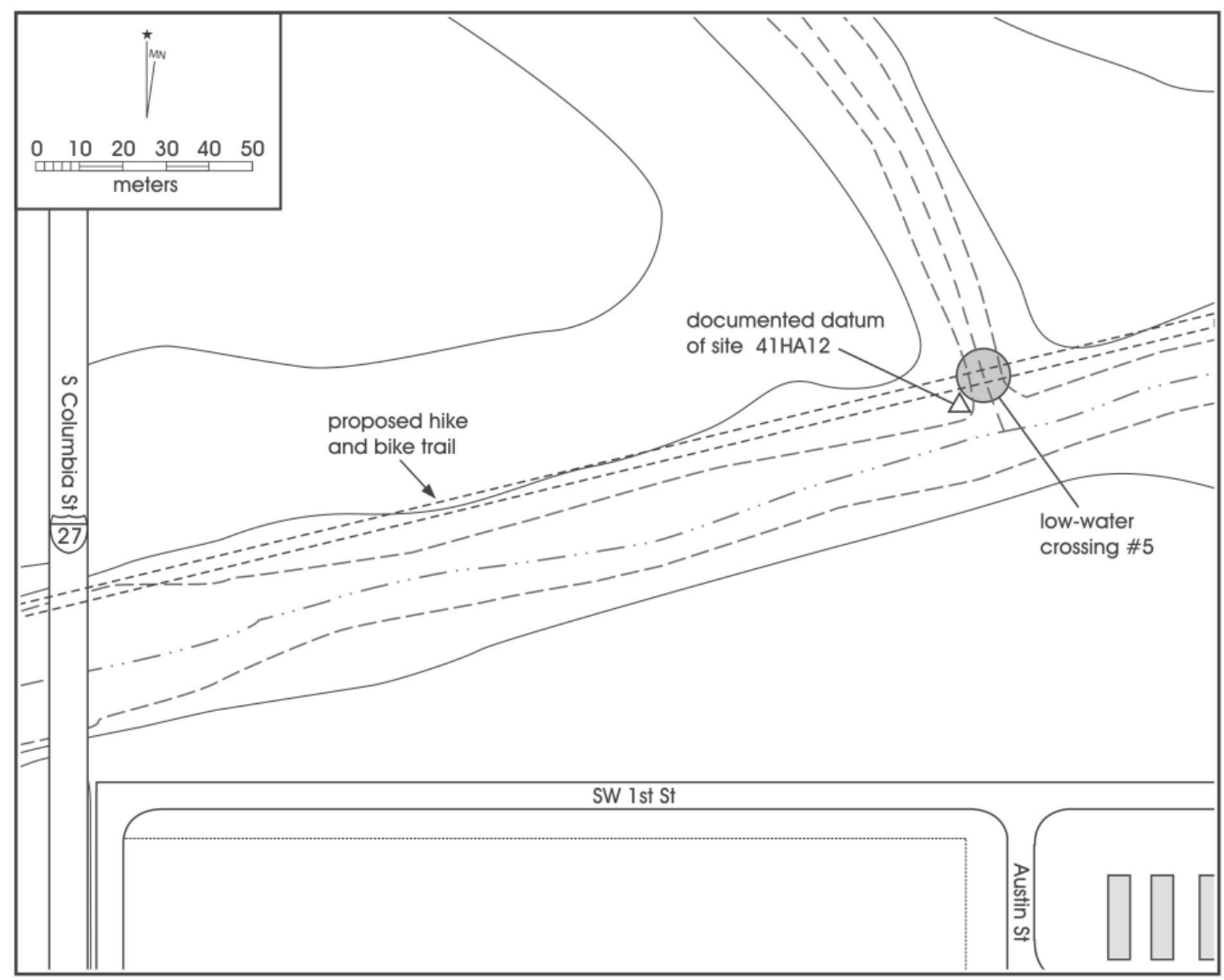

Figure 2-1. Location of 41HA12 site datum and Low-Water Crossing \#5.

bone, and numerous burned and fractured caliche pebbles (THC 2005).

Site 41 HA 5 is located immediately southwest of 41 HA 4 . This site was recorded as a 300-m-by-300-m lithic and ceramic scatter of Ceramic age. The cultural material present at the site included a dart point stem, side-notched arrow points, Black-on-White and brownware pottery fragments, Edwards, Tecovas, and chalcedony flakes, and burned caliche pebbles (THC 2005).

Additional sites have been recorded farther away from the project area, primarily along Running Water Draw. These are described briefly based on the information from the Texas Archeological Sites Atlas (THC 2005). Site 41HA6 was estimated to be $100-\mathrm{m}$ by $80-\mathrm{m}$ and contained one projectile point stem, a drill, brownware sherds, flakes from several raw material types (Alibates, Tecovas, and Edwards chert), and some possible fire-cracked rock. The other nearby sites are small and yielded minimal artifact collections. Several contained only one (41HA3, 41HA7, 41HA9) or no lithics (41HA10, 41HA11, 41HA13). Cultural assignment was based primarily on the presence of possible fire-cracked rock and few faunal remains. Sites 41HA10 and 41HA11 were recorded but lack definitive cultural evidence. Site 41HA2 and 41HA8 8 lie away from the Running Water Draw floodplain and have deep plowing disturbances. These provide only minimal evidence of prehistoric human activities. Site $41 \mathrm{HA} 2$ had a grinding slab on the surface, some possible fire-cracked rock, but no other lithics. Only a single flake was observed at $41 \mathrm{HA} 8$.

\section{The Plainview Site (41HA1)}

The Plainview type-site is situated in the immediate vicinity of one of the proposed low-water crossings (C4) for the hike and bike trail. The Plainview Site was first examined in the 1940s (Sellards et al. 1947; Speer 1990) and is where the Plainview projectile point form was first identified. The site was recorded by Glen Evans and Grayson Meade in 1944 who saw it exposed in the wall of a quarry pit for roadbed material. At the time of its discovery, quarrying activities had destroyed a portion of the site that was exposed in the southern margin of the Running Water Creek valley. Subsequent caliche excavations also have removed deposits that may have contained archeological materials. Eddie Guffee (1979) states that as late as 1973 , holes from excavations by relic collectors could be seen high up in the walls of the caliche quarry. Likewise, channelization of the creek that formerly 
ran in Running Water Draw is also likely to have impacted the archeological deposits, since the drainage ditch ran close to the southern margin of the valley. Finally, the use of the caliche quarry pits as large-scale historic dumping localities also may have affected the archeological deposits.

The first formal archeological excavations at the site occurred as a joint project of the Bureau of Economic Geology and the Texas Memorial Museum during the summer and fall of 1945. The excavations at the site amounted to about 500 square feet (Sellards et al. 1947:931). The locality yielded the remains of approximately 100 bison (Bison antiquus) and was one of the largest Paleoindian bone beds documented (Sellards et al. 1947:934). At least 28 projectile points and 15 other tools have been recovered from the bone bed deposits. Eighteen of these come from the original excavations at the site (Sellards et al. 1947:939).

Additional excavations were carried out between July 26 and December 18, 1976 and between April 29 and May 7, 1977, by the Archeological Research Laboratory of the Llano Estacado Museum. The primary goal of these excavations was to find and map this major Paleoindian site that was feared lost (Guffee 1979). The project also saved the site from being removed from the NRHP and assured the placement of the bronze Registered National Historic Landmark plaque in the location where stands today. A small, unworked lithic flake was the only artifact recovered from these excavations and little additional information was gained about the site other than some taphonomic information and bone measurements (Guffee 1979).

The present investigations were designed to locate the site boundary using the information from previous excavations (Figure 2-2). This endeavor proved to be problematic given the different attempts to find the site. For example, in 1976, the City of Plainview decided to attempt to relocate the 1945 excavations performed by Sellards, Meade, and Evans for the National Parks Service. The relocated portion of the site was described between two old caliche quarries and beneath an access road perpendicular to the channelized portion of Running Water Draw. That same year, David Proctor submitted a Texas Archeological Sites Atlas location form for the relocated portion of 41HA1. In the submission, Proctor estimated that the site was approximately $150 \mathrm{~m}$ southwest of the intersection of Joliet Street and the 1940 channel of Running Water Draw. Proctor also provided UTM coordinates for this newly relocated portion of the Plainview Site. The UTM coordinate location is approximately $12 \mathrm{~m}$ east of Proctor's written description. Eddie Guffee's report of the excavations in 1976 and 1977 identified the remaining portion of the site as likely being downstream (southeast) from the "kill area" investigated by Sellards, Evans, and Meade. After establishing a primary datum northwest of the intersection of Joliet Street and Running Water Draw, Guffee noted that it was 900 feet $(274.5 \mathrm{~m})$ from the datum to the grid center of his excavation block (Figure 2-2). Guffee also plotted 41HA1 onto the City of Plainview's Engineering Department map, which was included as Map 2 in the Plainview Site report (Guffee 1979). An additional alidade map made by Guffee in August off 1976 shows a slightly different site location (Figure 2-2).

Given that there is no agreement between the five competing grid-center locations and no way to differentiate between them accurately, CAR delineated the limits of 41HA1 to include all five. As a result, the approximate site limits are represented by the oval area running northwest/southeast along the southdescending bank of Running Water Draw in Figure 2-3.

The Plainview Site has been dated to approximately 10,000-9800 BP based on shell and bone; however, more precise chronological control on the archeological deposits was proposed after CAR's survey and trenching. Original interpretations of the site suggested that the bone bed accumulated "all at one time or within a short period of time" (Sellards et al. 1947:934). Recent analysis of the age structure and weathering of the bison remains suggest that multiple kill events are represented (Johnson and Holliday 1996). Holliday (1997:108-110) identifies several unresolved research problems regarding the site, such as the taphonomic dynamics of the bone bed, the relationship of the archeological remains and the stratigraphy, and more accurate dating of the site.

Some Paleoindian deposits may remain regardless of the extensive impacts that may have affected the site. Guffee's 1976 and 1977 excavations confirmed the presence of additional bone bed deposits (Guffee 1979). Indeed, conversations with Guffee (personal communication April 2005) confirmed that at the end of his excavations, an area measuring about $5 \mathrm{~m} 2$ may have remained of the bone bed. These deposits occur at a depth of three meters below the present ground surface. 


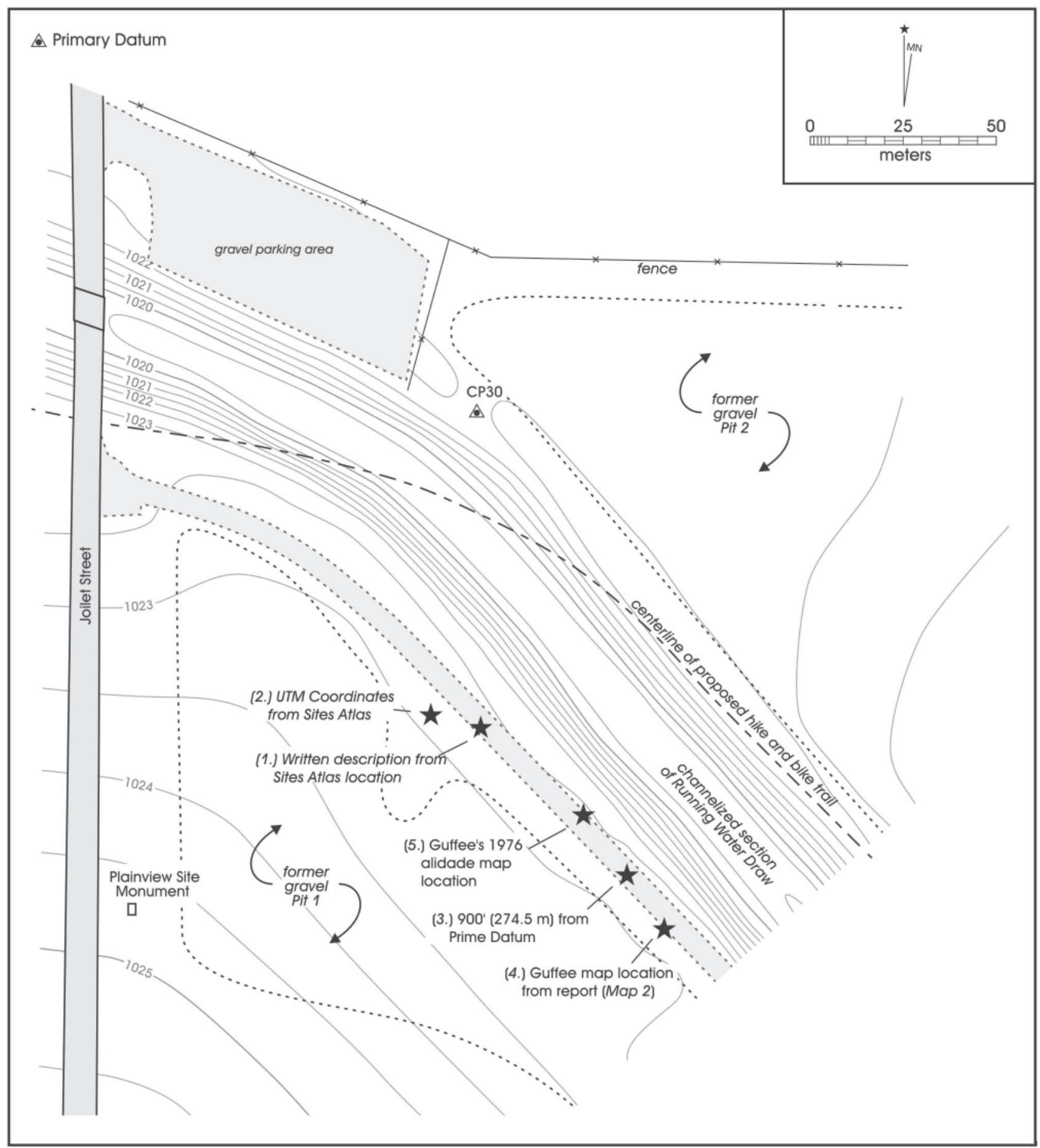

Figure 2-2. Identified locations of the Plainview Site from previous excavations. 


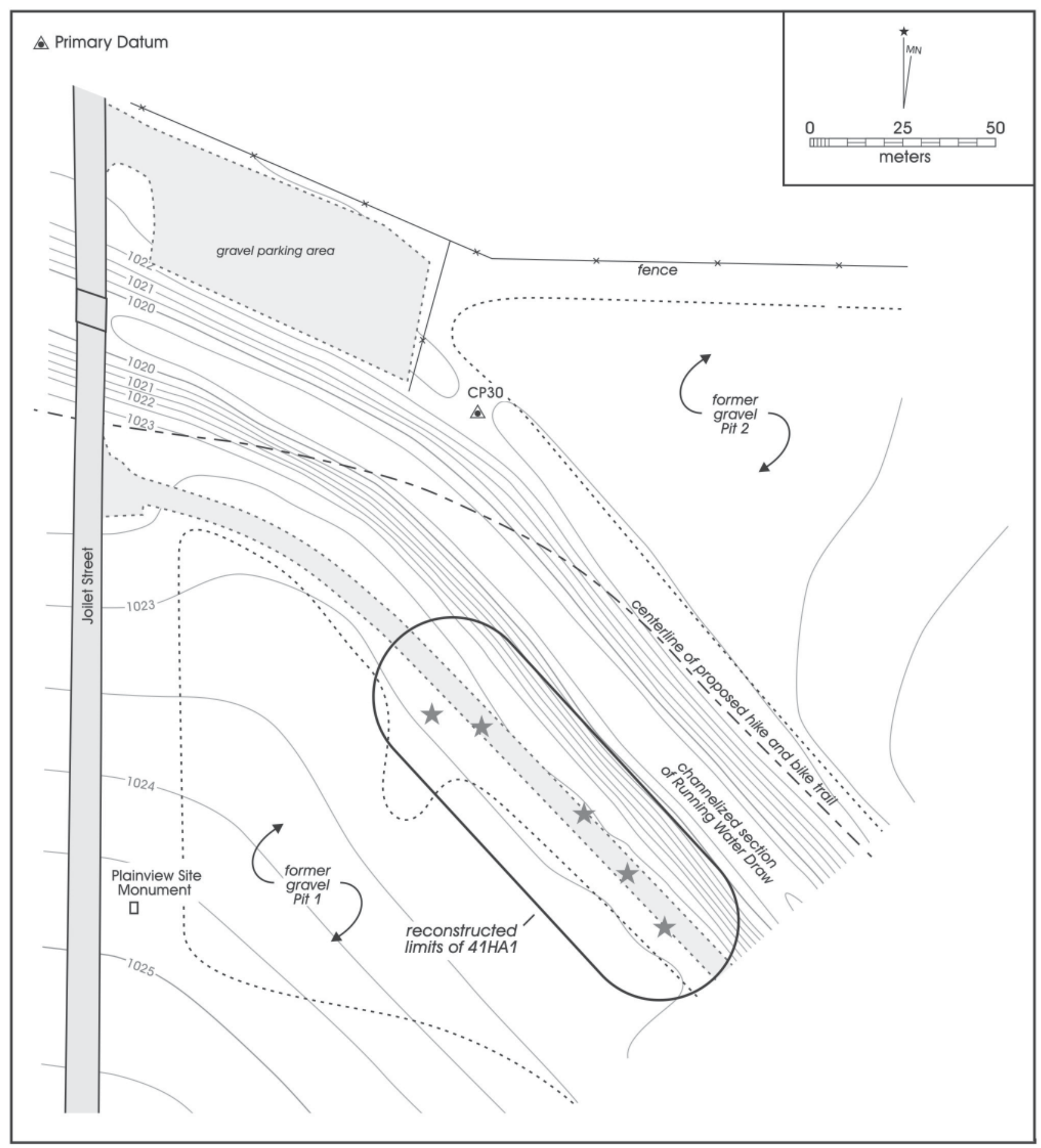

Figure 2-3. Proposed boundary of the Plainview Site. 


\section{Chapter 3: Geological Setting and Southern High Plains Geological Research}

\section{Previous Research on Alluvial Deposits on the Southern High Plain: Geologic Setting}

The project is situated entirely within or immediately adjacent to the Running Water Draw valley in Plainview, Texas. Only the segment on 4th Street between Quincy Street and Ennis Street (just east of Running Water Draw Regional Park) traversed the upland, and when this became apparent, no trenches were excavated in this segment. Running Water Draw is one of several small dry streams, named draws that drain the Southern High Plains. When these streams contain water, they flow to the southeast. Just east of the Llano Estacado, Running Water Draw flows into the White River, a tributary of the Brazos. Between the draws, the High Plains surface is a vast, gently eastward sloping surface, which largely lacks integrated drainage networks and is dotted with thousands of small depressions called playas that form seasonal wetlands or lakes.

The Southern High Plains is underlain by the Tertiary age Ogallala Formation, which is an extensive body of alluvial sand and gravel, and eolian sand that was eroded from the southern Rocky Mountains in New Mexico and deposited upon a vast outwash surface during the Miocene and Pliocene, roughly 8.3 to 2.8 million years ago (Gustavson and Finley 1985). This depositional surface was gradually abandoned as streams began to incise. In particular, the Pecos River cut off the Southern High Plains from the streams draining the Rocky Mountains, and the Canadian River separated the Llano Estacado from the High Plains to the north, gradually turning this surface into a vast mesa. This series of events started a prolonged period of soil development within the Ogallala Formation during which a massive indurated calcrete (a cemented calcic soil horizon) and subsequent silcrete formed. This deposit today is known as the Caprock caliche. The Ogallala can be subdivided internally, but this is primarily of local significance.

During the Pleistocene, a series of eolian sands were deflated from the Pecos River valley immediately southwest of the Southern High Plains and deposited on top of the Ogallala Formation. This series of eolian deposits, known as the Blackwater Draw Formation, becomes finer across the Llano Estacado from southwest to northeast (with increasing distance from their source), and they have been modified by long-term pedogenesis (cf. Holliday 1997:10-11). The Blackwater Draw Formation is the surficial deposit over much of the Southern High Plains today.
The modern landforms that comprise the Southern High Plains, namely the playas, a handful of larger perennial salt lakes or Salinas, and the draws, are all incised into the Blackwater Draw Formation, and in some cases into the underlying Ogallala Caprock caliche. In the case of Running Water Draw, the modern stream valley is incised into the Ogallala Formation caprock caliche. This deposit crops out locally along the margins of the draw in various places. A series of late Pleistocene and Holocene age sediments fill the draw valley; these are discussed in detail below.

\section{Late Quaternary Depositional History of Southern High Plains Draws}

Geological and geoarcheological investigations of the Late Pleistocene and Holocene alluvial deposits of the draws of the Southern High Plains have their origins in the discovery and interpretation of the oldest archeological sites in the region, namely Paleoindian sites. This history has been recently recounted in detail by Vance Holliday $(1997 ; 1995)$, who has not only spent many years investigating these small streams and their deposits, but also expended a considerable amount of time revisiting most of the Paleoindian sites of this region in an attempt to clarify the stratigraphic and geochronologic contexts of the Paleoindian occupations.

Although Holliday has published a number of discrete papers on alluvial deposits from different Paleoindian sites that are situated in draw deposits (see Holliday 1997 for a complete list), in 1995 he compiled this body of work into a monograph that recounts the history of geological investigation of the draws, and summarizes the lithologic record in a unified account. In this work, Stratigraphy and Paleoenvironments of Late Quaternary Valley Fills on the Southern High Plains, Holliday describes a lithostratigraphic sequence for the latest Pleistocene and Holocene deposits that comprises five distinct, geographically extensive and chronologically asynchronous stratigraphic units. Holliday recognizes local variation or facies within each of these major depositional units and uses a series of lower case letters to denote these variants. For instance, "d" indicates the diatomite facies, " $m$ " denotes a muddy facies most common in the valley axis, "s" for sandy, most often used for eolian sand, which is most common in the valley margin settings, "g" for gravelly, "si" for silty, and "c" for deposits rich in calcium carbonate. Where more complex stratigraphic relationships are present, he uses numbers after the facies letter to denote the relative place of each deposit within the stratum. So, for instance, if there were two sandy 
deposits of stratum 4, Holliday would denote these deposits as $4 \mathrm{~s} 1$ and $4 \mathrm{~s} 2$, with $4 \mathrm{~s} 1$ being the older of the two. Many of the deposits in Holliday's lithostratigraphic sequence are visually and lithologically distinctive, and are relatively easy to recognize given the detailed nature of Holliday's fieldwork.

Although there are older, late Pleistocene age deposits in many draws that Holliday groups into what he calls "The Older Valley Fill “(cf. Frederick 1994:54-57; Holliday1995:1522), the majority of Holliday's stratigraphic work pertains to deposits that comprise the latest Pleistocene and Holocene periods which he refers to as "The Younger Valley Fill".

\section{The Younger Valley Fill}

The first deposit of the Younger Fill in most draws is an alluvial deposit Holliday calls Stratum 1, which is comprised of alluvial sand and gravel deposited in the Late Pleistocene between roughly 20,000 and 11,000 years BP. Although there is some local variation across the region, Stratum 1 is typically very distinctive in its coarse texture, reasonably good sorting, and white color. In some locations, it is overlain by a deposit of low carbonate to noncalcareous mud and/or diatomite that is named Stratum 2 by Holliday (1995:35-37). Stratum 2 is widely known from Paleoindian sites across the region but is relatively rare, having been observed at only about 15 percent of the localities Holliday has studied over the years. This unit is well dated and has yielded radiocarbon ages between 11,000 and 9,000 years BP.

The next unit, Stratum 3, is one of the most distinctive and widespread deposits in the region. It comprises an alluvial deposit that is rich in calcium carbonate, often referred to as a marl, and in many sections a weak soil (named the Yellowhouse Soil) is present at the top of the unit. Deposition of Stratum 3 varies considerably from one draw to another, as well as within a single draw, but at the regional scale has been bracketed to a wide period in the early Holocene from roughly 10,000 to 7,500 years BP.

Stratum 3 is usually overlain by Stratum 4, which is a sheet-like body of sandy to loamy sediment within which a prominent soil has formed, the Lubbock Lake Soil. Holliday (1995:38-40) notes that this unit often coarsens towards the valley margin, and he associates it with eolian deposition during the middle Holocene, roughly between 7500 and 4500 years BP (cf. Holliday 1995:32, Figure 19). In many draws, Holliday notes that the Lubbock Lake Soil is the surface soil, and the development of this soil has occurred throughout the latter half of the Holocene.
The last unit formally recognized by Holliday (1995:41-42) is Stratum 5, which represents alluvial sedimentation in the late Holocene, post 3900 years BP. Apparently many draws failed to experience significant sedimentation in the Late Holocene (see Holliday 1995:32, Figure 19), but a wide range of facies variation is recorded by Holliday for Stratum 5 in a few places, one of which is Running Water Draw. Stratum 5 appears to have been deposited in an episodic fashion, and is described as having an upper and lower part, each part of which is capped by a weakly developed soil. Unlike other soils described for early and middle Holocene deposits, which Holliday describes as regionally significant, the buried soils associated with Stratum 5 at Lubbock Lake (the Apache and Singer soils) do not extend across the region owing to the localized nature of Stratum 5 deposition. Holliday (1995:42) also notes that in Running Water Draw there is some evidence of erosion and channel trenching from one locality, specifically the point where Quincy Street crosses the draw. At this locality, while working with Glenn Goode and TxDOT, Holliday (1995:42) observed "a deep channel $(>300 \mathrm{~cm})$ was cut into stratum 4 and filled with layers of gravel, sand, loam, mud and carbonate. This channel contains the only evidence of late Holocene alluviation documented in any of the draws examined as a part of this study".

\section{Studies of the Deposits of Running Water Draw and the Plainview Site}

All of the existing work that has been performed on the late Quaternary deposits of Running Water Draw is related to the Plainview Site (41HA1) discovery and subsequent attempts to better understand the age and stratigraphic context of the Plainview Site bone bed. For a variety of reasons that are not well understood, the age of the Plainview type site is poorly known, and has proven quite difficult to pin down with any accuracy (see Holliday et al. (1999) for one of the most recent attempts to obtain closure on this issue). Between Sellards et al. (1947) original report, Speers (1990) and Holliday (1997:103-110), it is possible to obtain a clear understanding of the sequence of events surrounding the Plainview discovery and subsequent history of the site and its immediate environs. Nearly all the work that has been done on the alluvial history of Running Water Draw has been done by Vance Holliday $(1985 ; 1990 ; 1997)$ and has relied heavily upon borrow pit exposures on the valley floor.

The Quaternary deposits of Running Water Draw have, for some time, been used as a source of fill earth for roads and the development of the City of Plainview. The Plainview Site was discovered during the excavation of one such quarry that was removing the Ogallala Formation caprock caliche for road base, a quarry that was expanded north into the Running Water Draw valley (see Figure 3-1). Holliday (1985) refers to the quarry pits in proximity to the Plainview 


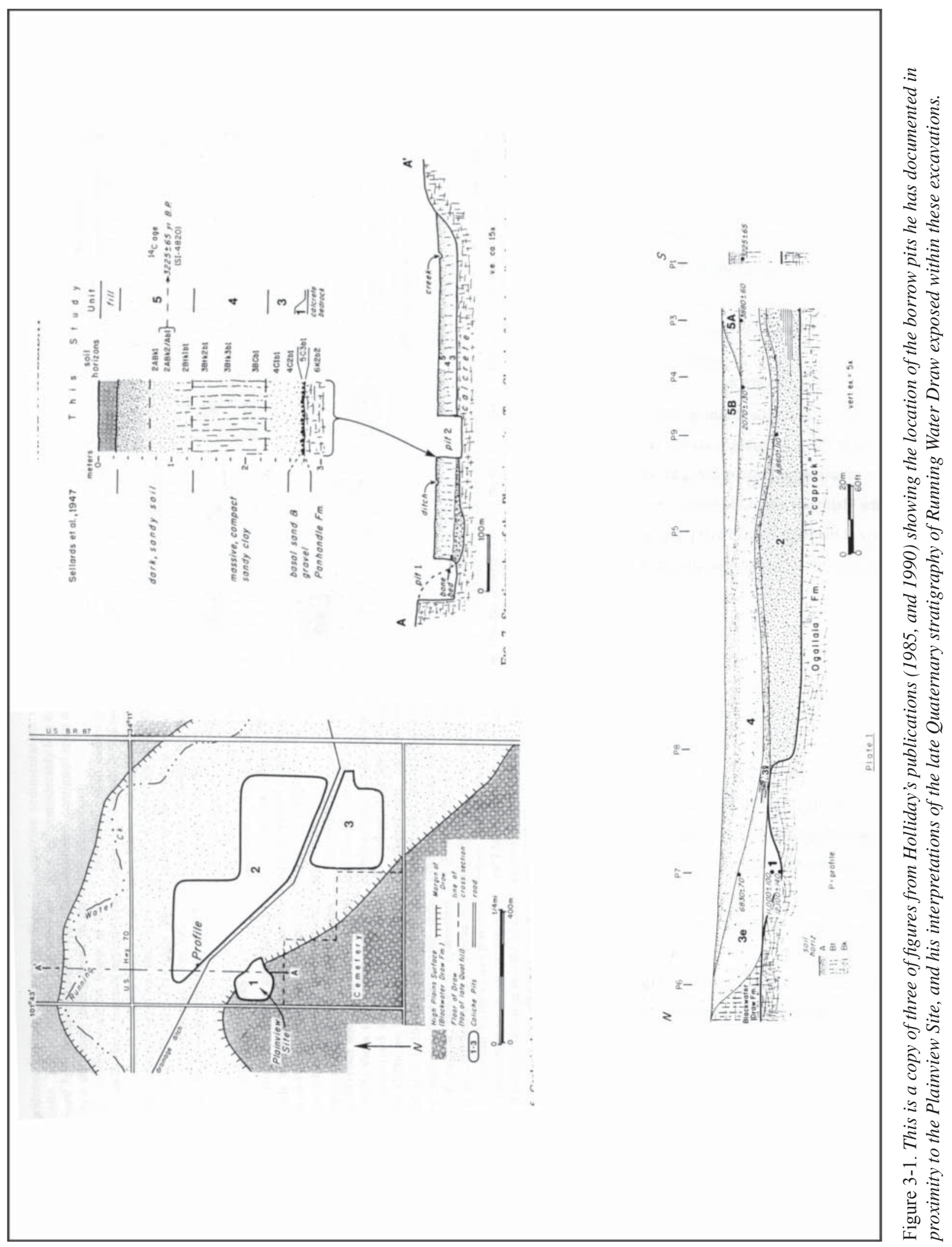


Site as Pit 1 (where the site was originally found), Pit 2 (the large quarry north of the drainage ditch), and Pit 3 (the extant quarry pit situated southeast of Pit 1 and behind the Plainview Cemetery). For the sake of consistency, this report will retain Holliday's nomenclature for the pits. Following the archeological excavation and subsequent completion as a borrow pit, the Plainview Site quarry was back filled with rubbish so that today the site, which fronts on Joliet Street, looks like an open field. It should be noted that the boundary of Pit 1, as shown on many publications (e.g. Holliday 1985; Sellards et al. 1947), depicts the pit as it was when Sellards et al. (1947) excavated the Plainview Site. The final dimensions of this pit were eventually considerably larger, mostly expanded north and east to the margins of a "drainage ditch", which is today the active channel of Running Water Draw. Although Holliday (1997:103) notes that this pit was expanded, none of the maps in the published literature show the true areal extent of Pit 1.

Of the three borrow pits that Holliday has illustrated, only Pit 3 retains a visible exposure of the draw deposits today. Holliday has published descriptions of the deposits exposed in both Pit 2 and Pit 3 (e.g. 1985; 1990; 1995; 1997), but unlike many of the

Paleoindian type sites in this region, the deposits of the Plainview Site are not available for examination today. Most of Holliday's work has been done in order to reconstruct what must have been present during the original excavation by Sellards et al. (1947).

Were it not for the presence of the "drainage ditch" (the channelized course of Running Water Draw that diverts flow within the draw away from downtown Plainview), all of the deposits associated with the Plainview Site would have been mined away years ago. However, because this ditch predates the quarry, the quarry boundaries respect it, and as a result the presence of the ditch thereby preserves two narrow ribbons of the natural deposits that provide the only remaining evidence of the Plainview Site. It is likely that the pit boundary along Joliet Road may also retain a useful section of the Draw deposits, but like everything else near the original site, this boundary is obscured by fill earth and revetted with garbage. The only work done at the site since Sellards et al. (1947) was an excavation in 1976 and 1977 by Eddie Guffee (1979) that was funded by the City of Plainview in order to determine if any of the site deposits remained. This work excavated beneath the access road that bordered the drainage ditch and ran along the ribbon of intact sediment that separates the landfill/quarry excavation from the ditch. This excavation succeeded in recovering bones that were presumed to be from the site, but Guffee concluded that the bones in his excavation were in secondary context and had been moved by the stream.

The stratigraphy of Running Water Draw described by Holliday $(1997 ; 1995)$ is generally consistent with his overall lithostratigraphic sequence and summarized below on Table 3-1. The majority of this work derives from the description and sampling of a long cut in Pit 3 that parallels Joliet Street and is nearly perpendicular to Running Water Draw (Holliday 1990). Pit 3 is nearly $400 \mathrm{~m}$ from 41HA1. The closest profile Holliday (1985) has to 41HA1 was a profile from the northwest end of Pit 2 near the channelized course of Running Water Draw.

Table 3-1. Stratigraphic Framework for Running Water Draw, from Holliday (1995)

\begin{tabular}{|c|c|c|c|}
\hline Stratum & Lithology/Facies & Radiocarbon Ages available from Running Water Draw & Locality \\
\hline 5 & 5s: alluvial sand & $<3,900$ yrs BP in general $\cdot 3,225 \pm 65$ (base of $5 \mathrm{~m})$ & $\begin{array}{c}\text { Profile S2, Pit } 3 \\
\text { Holliday } 1995\end{array}$ \\
\hline 4 & $\begin{array}{c}\text { 4s:sandy facies, some of which are } \\
\text { eolian, others alluvial } \\
\text { 4m: overbank mud facies }\end{array}$ & $\begin{array}{c}7,500-4,000 \text { yrs BP in general } \\
2,070 \pm 130 \text { (soil below } 5 \mathrm{~s} 2 \text { ) } \\
3,880 \pm 60 \text { (soil below } 5 \mathrm{~s} 1 \text { ) }\end{array}$ & $\begin{array}{c}\text { Pit 3; } \\
\text { Holliday 1995:45 }\end{array}$ \\
\hline 3 & $\begin{array}{l}\text { 3m: palustrine-lacustrine marl } \\
\text { 3s: eolian sand }\end{array}$ & $\begin{array}{c}10,000-7,500 \text { yrs BP in general } \\
6,770 \pm 50 \text { (buried soil at top) }\end{array}$ & $\begin{array}{c}\text { Pit 3; } \\
\text { Holliday 1995:45 }\end{array}$ \\
\hline 2 & 2m: palustrine-lacustrine mud & $\begin{array}{c}11,000-9,000 \text { yrs BP in general } \\
8,860 \pm 110(2 \mathrm{~m})\end{array}$ & $\begin{array}{c}\text { Pit 3; } \\
\text { Holliday 1995:45 }\end{array}$ \\
\hline 1 & $\begin{array}{l}\text { 1: channel sand and gravel } \\
\text { 1m: palustrine-lacustrine mud }\end{array}$ & $\begin{array}{l}\text { Initial phase of deposition is unknown, but it ends between } \\
11,000 \text { and } 9,500 \text { yrs BP, in general } \\
10,940 \pm 170 \text { (top of } 1 \mathrm{~m} \text { ) } \\
11,970 \pm 140 \text { (near base of } 1 \mathrm{~m} \text { ) }\end{array}$ & $\begin{array}{c}\text { Pit 3; } \\
\text { Holliday 1995:45 }\end{array}$ \\
\hline
\end{tabular}

The path of the hike and bike trail is the closest approach any excavation has made to the Plainview Site since Guffee's excavation. Since the path construction was to remove some of the remaining ribbon of sediment in the same approximate position as the Plainview Bone bed, the deposits within the right-of-way were closely inspected and a column of sediment samples collected for analysis. Neither Sellards et al. (1947) nor Guffee (1979) preserved anything more than a sketch of the stratigraphy exposed by their excavations. 


\section{Chapter 4: Field and Laboratory Procedures}

\section{Field Procedures}

An intensive pedestrian survey of the entire length of the hike and bike trail was performed prior to subsurface investigations to record any archeological sites visible on the surface and to locate high probability areas requiring further work. The hike and bike trail was walked systematically east to west starting at Broadway Park following the ROW stakes placed by TxDOT. Note that the ROW used in the figures presented in this report has been modified from the original route provided by TXDOT to match the staked centerline noted by crews during this survey.

\section{Auger Tests}

All auger tests were dug using a 12-inch-diameter auger bore attached to a Bobcat. The auger borings were excavated to a maximum depth of $120 \mathrm{~cm}$ below surface, unless otherwise prevented from reaching this depth. They were excavated in four $30-\mathrm{cm}$ levels. All sediments removed from these tests were screened through $1 / 4$-inch mesh. All artifacts, including recent artifacts, were collected and observations were recorded on standardized forms. A form was completed for every excavated auger bore. The location of each excavated auger bore was recorded using a hand-held Trimble GPS unit.

\section{Gradall Trenches}

All trench excavations were carefully monitored by an archeologist. Upon suspicion of faunal or cultural remains, excavation of the trench ceased and the area and backdirt were carefully examined. Faunal remains were removed from the trench walls using trowels and brushes after provenience was noted and photographs were taken for documentation purposes. Each wall of the trench was troweled and examined for evidence of archeological artifacts, features, or indications of formation events.

Most trenches were less than two meters deep, although a few were as deep as three meters. The deepest exposures were made in proximity to $41 \mathrm{HA} 1$ on the sloping edge of the draw, and the trench was excavated in a stair step manner into the slope. Upon completion of the trench, one wall of each trench was cleaned with a knife and/or a trowel while searching for cultural material and the exposure was described (see Appendix C). Where there was significant lateral variation within the trench, a drawing of one wall was made by erecting an arbitrary elevation string line and drawing the position of each deposit with respect to the string line. If no significant lateral variation was apparent, a single vertical profile was described. Field descriptions were made in general accordance with Schoeneberger et al. (2002) except that the primary unit of field observation was a generic one termed a zone, that is employed to permit full description of both sedimentologic as well as pedogenic features. In a few locations, samples were collected for radiocarbon dating. Short columns of sediment samples for diatom analysis were collected in three locations and in one locality, a column of bulk sediment samples was pulled for full characterization of the deposits. Table 3-1 lists the trenches with respect to six specific segments of the pathway between major cross streets.

Photographs of the profiles were also taken and the location of each trench was recorded using a hand-held Trimble GPS unit.

\section{Archeological Laboratory Procedures}

After completion of fieldwork, all documents generated, the single projectile point recovered, ecofacts (i.e., non-cultural animal bones) and soil samples were returned to the CAR laboratory to be processed and catalogued according to CAR's standard practices. The single projectile point was washed, air-dried, and stored in an archival-quality bag with acid-free labels displaying provenience information and a corresponding lot number laser printed or written in pencil. The materials recovered were stored in acid-free boxes identified with standard labels. The data were entered into a Microsoft Access database. The single artifact recovered and all project related documentation, including the photographs are permanently curated at CAR.

Field notes, forms, and hard copies of photographs were placed in labeled archival folders. All field forms were completed in pencil. Documents and forms were printed on acid-free paper and any soiled forms were placed in archivalquality page protectors.

\section{Geological Laboratory Methods}

Twenty-nine bulk sediment samples were collected in the field from Trench 20 near 41HA1. These samples were processed for granuometry, calcium carbonate content, total carboninorganic carbon-organic carbon, stable carbon isotopic 
ratio analysis, magnetic susceptibility. The specific methods employed for their analysis are described below. Short columns of diatom samples were collected from this trench, and two others and submitted to Dr. Barbara Winsborough for analysis. The results of this work are summarized below but discussed in detail in Winsborough (2007; Appendix A, this volume). Geochronology for Trench 20 is provided by two optically stimulated luminescence samples that were collected and subsequently submitted to the Luminescence Lab, Sheffield Centre for International Drylands Research for single grain dating. The methods employed and results obtained from this work are described in detail by Bateman (2007; Appendix B, this volume).

\section{Particle Size Analysis (Texture)}

Texture analysis was performed using the hydrometer-sieve method (cf. ASTM 1985; Gee and Bauder 1986; Bouyoucos 1962). For this analysis, the total sample was air dried and weighed, then crushed with a rubber pestle and mortar, and subsequently passed through a $2 \mathrm{~mm}$ sieve. Material caught on the $2 \mathrm{~mm}$ sieve, if detrital material, was then sieved at a 1 phi interval and the mass on each sieve recorded. A split of the $<2 \mathrm{~mm}$ size material (roughly 40 grams) was then soaked in $50 \mathrm{ml}$ of a $5 \%$ sodium hexametaphosphate solution overnight, and then mixed in a mechanical mixer for 5 minutes before being diluted to 1 liter with distilled water. This mixture was placed in a 1 liter settling jar, mechanically agitated for 1 minute, and then set on a table, after which point hydrometer readings were made at different time intervals (specifically 1 , $3.5,15,45,300$, and 1440 minutes). A control hydrometer and temperature reading on an empty jar with nothing but distilled water and the sodium hexametaphosphate solution was made at intervals throughout the analysis to permit calibration of the hydrometer. A small split of the $<2 \mathrm{~mm}$ soil was also oven dried to determine the moisture content and correct the sample mass used in the hydrometer analysis (hygroscopic moisture correction). After 24 hours, the contents of the hydrometer jar were wet sieved through a 37 micron sieve, and the sand retained on the sieve was transferred to a beaker and oven dried at $105^{\circ} \mathrm{C}$. This sand was subsequently sieved at 0.5 phi intervals once dry and the mass retained on each sieve recorded. From these data the percentage of gravel, sand, silt and clay, as well as various descriptive statistics were calculated for the grain size distribution using a spreadsheet written by Paul Lehman.

\section{Calcium Carbonate Content (C.C.E)}

A $1.7 \mathrm{~g}$ split of the ground $<2 \mathrm{~mm}$ fraction of each soil sample was used to determine the calcium carbonate equivalent (C.C.E.) by means of a Chittick apparatus (Dreimanis 1962; Machette 1986). This sample was finely ground (to pass a 0.075 $\mathrm{mm}$ sieve) and then weighed and placed into a small $(250 \mathrm{ml})$ Erlenmeyer flask. Once attached to the Chittick apparatus, the liquid level in the measuring burette was set to $-10 \mathrm{ml}$ and the stopcock was closed so no gas could leave the system. The leveling bulb was dropped in order to establish a vacuum inside the sample chamber. At this point, the barometric pressure and temperature in the room were recorded. Then $10 \mathrm{ml}$ of $50 \%$ hydrochloric acid (ca. $6 \mathrm{~N} \mathrm{HCl}$ ) was delivered to the sample flask, which was agitated intermittently until the reaction had ceased (usually 1-2 minutes). At this point, the leveling bulb was raised to the point that the liquid level inside of it was equal in elevation to the liquid in the burette, and the volume of gas evolved was then measured and the calcium carbonate equivalent calculated.

\section{Total Carbon, Organic Carbon, and Inorganic Carbon}

In order to determine the carbon content of each sample, splits of the $<2 \mathrm{~mm}$ size fraction were submitted to the Analytical Chemistry Lab at Institute of Ecology, University of Georgia. Total carbon and total organic content was determined on a Micro-Dumas NA1500 Combustion Elemental (C/H/N) Analyzer (Carlo Erba Strumentazione, Milan). Details of the procedures used may be found on the institute's web page (http://www.uga.edu/ sisbl/soilerb.html) and general aspects of the method are discussed by Schulte and Hopkins (1996). Organic carbon content was determined from a 2 gram split of the $<2 \mathrm{~mm}$ size soil was treated with $6 \mathrm{~N} \mathrm{HCl}$ to remove calcium carbonate, rinsed repeatedly, subsequently dried at $105^{\circ} \mathrm{C}$, and then finely ground once dry. Total inorganic carbon was calculated as the difference between total carbon and total organic carbon.

\section{Stable Carbon Isotopes}

The stable carbon isotopic value of the organic carbon for each sample was determined at the Stable Isotope/Soil Biology Laboratory at Institute of Ecology, University of Georgia. These values were defined from the carbonate free $<2 \mathrm{~mm}$ soil used to determine the organic carbon content and were measured on a element ratio mass spectrometer by converting the organic carbon to a gas phase by extremely rapid and complete flash combustion of the sample material.

\section{Magnetic Susceptibility}

The reversible, low frequency mass magnetic susceptibility of the samples were determined by filling a 1 inch plastic cube with air dried $<2 \mathrm{~mm}$ size material from each sample. The samples were then weighed and the low frequency magnetic susceptibility was measured on a Bartington MS2 meter and MS2B sensor. Each value was measured twice and the average values were used to calculate the reversible, low frequency mass susceptibility ( $\chi \mathrm{lf}$ ) which is reported in SI units $\left(10^{-8} \mathrm{~m}^{3} \mathrm{~kg}^{-1}\right)$. The precise methods and equations used may be found in Gale and Hoare (1991:222-226). 


\section{Chapter 5: Research Themes}

The Southern High Plains is arguably the most intensively studied Quaternary landscape in the State of Texas. The general stratigraphy and trajectory of late Quaternary environmental change in this region is well known largely owing to the efforts of a single person, Vance Holliday. Holliday has documented the geology of a wide range of landforms in this landscape, ranging from the streams or draws (Holliday 1995), to eolian environments (Holliday 2001; Muhs and Holliday1995) as well as the site-specific geology of many of the Paleoindian sites in this region (Holliday 1997).

The Plainview Site (41HA1) is one of a handful of Paleoindian type-sites in this region, and its stratigraphy has been described by Sellards et al. (1947) and Holliday (1985a; 1985b; 1990; 1997). The stratigraphy of Running Water Draw and the Plainview Site with respect to other draws on the southern High Plains is discussed by Holliday (1995). The most recent fieldwork at the Plainview Site is Guffee's (1979) excavations, which occurred in 1976-1977.

The work performed by CAR for this project involved the examination of backhoe trenches at increments along Running Water Draw through the City of Plainview. Two of these trenches (GT20 and GT21) were located in direct proximity to $41 \mathrm{HA} 1$. Table $5-1$ presents the list of trenches investigated, the stratigraphic units exposed and identified, and the samples collected from each trench and unit.

The observations we collected are relevant to three specific research themes: 1) the late Quaternary stratigraphy of Running Water Draw, 2) the late Quaternary paleoenvironments of Running Water Draw, and 3) the age and stratigraphic context of the Plainview Site.

\section{Theme 1: Late Quaternary Stratigraphy of Running Water Draw}

Our fieldwork revealed stratigraphic complexities not previously described by Holliday. Specifically, we observed cut and fill features on the main valley floor: 1$)$ the presumed Unit 5 channel which was exposed in two trenches (GT10 and GT11) and 2) in association with the most recent channel of Running Water Draw (GT4). Holliday (personal communication, 2005) may have seen one of these but neither of them is described in the existing literature dealing with the site specifically or with Running Water Draw in general.
Discussions with Vance Holliday confirm fieldwork-derived impressions that the Unit 6 channel complex is probably not represented in his stratigraphic sequence. He may have seen this deposit in a series of trenches excavated by TxDOT and Glen Goode on the south side of the draw on Quincy Street. Holliday $(1995: 42$; 117) describes a channel complex cut 3 $\mathrm{m}$ into Unit 4 at the Quincy Street excavations, that yielded a date of $2600 \pm 40$ years BP (Holliday 1995:124), and that "this channel contains the only evidence of late Holocene alluviation documented in any of the draws examined as part of this study" (Holliday 1995:42). Whether this was the Unit 6 channel or the Unit 5 channel is not known. It is somewhat surprising to learn that the Quincy Street trench revealed the only late Holocene alluvial channel in a Southern High Plains Draw known to Holliday and this may be a tacit commentary on the perils of relying upon cores for stratigraphic work.

In summary, it is clear that the work for this project documented two different age late Holocene alluvial channels, Unit 6 and Unit 5, and that the one Holliday describes above is probably the one beneath the T1 surface rather than the deposit beneath the floodplain of the most recent channel. However, the only way to be certain is to date both of these channels.

\section{Available Data Types}

Although no bulk samples were collected from these deposits explicitly for dating purposes, five bulk samples were collected from GT10 (n=2) and GT11 $(n=3)$ for analysis of the snail assemblage, and these could be used for radiocarbon dating. In the field, we assumed that if these Unit 5 deposits were to be dated, the best material would be bone, of which there are numerous samples from each trench to choose from (Table 5-2). In GT10, most of the bone (4,468 g) comes from one stratigraphic position, the interface between a dark mud at the base of the channel and a prominent cross-bedded coarse sand at 1.60-1.65 mbs, within which there were large numbers the bison remains. In GT11, bone was recovered from three different stratigraphic positions ranging from the base of the channel between 1.45-1.55 mbs to about midway up the channel fill at about $.71 \mathrm{mbs}$ where a bison skull was recovered. We proposed to date two stratigraphically ordered samples, one from the deepest levels (@1.55 mbs) and one from near the top of the bone deposit (@.71 mbs). One bone collagen sample from GT10 was submitted from $1.60 \mathrm{mbd}$ and two bone collagen samples were submitted from GT11, one from $.71 \mathrm{mbs}$ and one from $1.55 \mathrm{mbs}$. These were sent to Beta Analytic for radiocarbon dating. 
Table 5-1. List of Trenches, the Stratigraphic Units Exposed, and Samples Collected during Fieldwork

\begin{tabular}{|c|c|c|}
\hline Trench & Strata Exposed & Samples Collected \\
\hline GT1 & All recent fill. & None \\
\hline GT2 & $\begin{array}{l}\cdot 0-30 \mathrm{~cm}: \text { disturbed } \\
\cdot 30-82 \mathrm{~cm}: \text { Units } 5 \mathrm{~m} \\
\cdot 82-155 \mathrm{~cm}: \text { Unit } 4 \mathrm{~m} \text { with prominent buried soil } \\
\text { between } 82 \text { and } 109 \mathrm{~cm}\end{array}$ & None \\
\hline GT3 & $\begin{array}{l}\cdot 0-80 \mathrm{~cm} \text { : recent fill; } \\
\cdot 80-130 \mathrm{~cm} \text { : base of Unit } 4 / 5 \mathrm{~m} \\
\text { - } 130-155 \mathrm{~cm} \text { : Unit } 3 \text { marl with a buried soil at top } \\
\text { between } 130-140 \mathrm{~cm} \text { (correlative with Yellowhouse } \\
\text { Soil?). }\end{array}$ & None \\
\hline GT4 & $\begin{array}{l}\cdot 0-20 \mathrm{~cm} \text { : recent fill } \\
\cdot 20-125 \text { : Unit } 6 \mathrm{~b} \text { channel/floodplain deposits with } \\
\text { prominent buried soil between } 20-40 \mathrm{~cm} \\
\cdot 125-230 \mathrm{~cm} \text { : Unit } 6 \text { a with buried soil between } 125- \\
145 \mathrm{~cm} \text {; } \\
\cdot 230-240 \mathrm{~cm} \text { : Unit } 1\end{array}$ & $\begin{array}{l}\text { - Two bulk sediment radiocarbon samples, one from mud near base } \\
\text { of Unit } 6 \text { a at } 200-205 \mathrm{~cm} \text {, and another from the buried soil at top of } \\
\text { Unit } 6 \text { a at } 125-128 \mathrm{~cm} \text {. } \\
\text { - Several bones suitable for radiocarbon dating }\end{array}$ \\
\hline GT5 & $\begin{array}{l}\cdot 0-130 \mathrm{~cm} \text { : Unit } 5 \mathrm{~m} \text { floodplain facies } \\
\cdot 130-220 \mathrm{~cm} \text { : Unit } 4 \mathrm{~m} \text { floodplain facies }\end{array}$ & $\begin{array}{l}\text { - Two bulk sediment radiocarbon samples; one from top of buried } \\
\text { soil in the middle of the profile (ca. } 132-139 \mathrm{~cm} \text {, at top of Unit } \\
4 \mathrm{~m} \text { buried soil) and a second on a mud drape within the Unit } 5 \\
\text { floodplain deposits at } 88-90 \mathrm{~cm} \text {. }\end{array}$ \\
\hline GT6 & $\begin{array}{l}\cdot 0-114 \mathrm{~cm} \text { : Unit 4/5m floodplain facies } \\
\cdot 114-190 \mathrm{~cm} \text { : Unit } 3 \text { marl, paleosol between 114-139 } \\
\mathrm{cm} \\
\cdot 190-265 \mathrm{~cm} \text { : Unit } 1\end{array}$ & $\begin{array}{l}\text { - One bulk sediment radiocarbon sample collected from top of } \\
\text { soil formed at the top of what appeared to be the Unit } 3 \text { marl } \\
\text { (presumably correlative with Holliday's Yellowhouse Soil at Lubbock } \\
\text { Lake). }\end{array}$ \\
\hline GT7 & $\begin{array}{l}{ }^{*} 0-30 \mathrm{~cm} \text { : landfill trash } \\
\cdot 30-140 \mathrm{~cm} \text { : Unit } 4 / 5 \mathrm{~m}\end{array}$ & None \\
\hline GT8 & $\begin{array}{l}\cdot 0-100 \mathrm{~cm} \text { : landfill trash and earth fill } \\
\cdot 100-140 \mathrm{~cm} \text { : undisturbed alluvium, age unknown. }\end{array}$ & None \\
\hline GT9 & $\begin{array}{l}\cdot 0-105 \mathrm{~cm} \text { : Unit } 5 \mathrm{~m} \text { floodplain facies } \\
\cdot 105-150 \mathrm{~cm} \text { : Unit } 4 \mathrm{~m} \text { floodplain facies }\end{array}$ & None \\
\hline GT10 & $\begin{array}{l}\text { - Complex stratigraphic relationships in trench } \\
\text { preclude simple depth description of units; } \\
\text { - Unit } 4 \mathrm{~m} \text { overlain by Unit } 5 \mathrm{~m} \text { floodplain facies at } \\
\text { north end of trench, and a channel of Unit } 5 \text { truncates } \\
\text { unit } 4 \text { in the north end of the trench. }\end{array}$ & $\begin{array}{l}\text { - Short column of diatom samples collected through wetland } \\
\text { sediments; } \\
\text { - Two quart size bags of bulk sediment for snails; } \\
\text { - Numerous bones suitable for radiocarbon dating (including two } \\
\text { bison skulls). }\end{array}$ \\
\hline GT11 & $\begin{array}{l}\text { - Complex stratigraphic relationships in trench } \\
\text { preclude simple depth description of units; } \\
\text { - Caprock Caliche, overlain Unit } 1 \text {, overlain by three } \\
\text { phases of floodplain sedimentation and associated } \\
\text { soils (Units } 4 / 5 \mathrm{~m}) \text {; Unit } 5 \text { channel; and a thin wedge of } \\
\text { recent dredge spoil(?). }\end{array}$ & $\begin{array}{l}\text { - Three quart size bags of bulk sediment for snails; } \\
\text { - Numerous bones suitable for radiocarbon dating. }\end{array}$ \\
\hline
\end{tabular}


Table 5-1. Continued...

\begin{tabular}{|c|c|c|}
\hline Trench & Strata Exposed & Samples Collected \\
\hline GT12 & $\begin{array}{l}\cdot 0-120 \mathrm{~cm}: \text { Unit } 4 / 5 \mathrm{~m} \\
\cdot 120-140 \mathrm{~cm}: \text { Unit } 3 \text { marl } \\
\cdot 140-220 \mathrm{~cm}: \text { Unit } 1\end{array}$ & None \\
\hline GT13 & $\begin{array}{l}\text { - Complex stratigraphic relationships in trench } \\
\text { preclude simple depth description of units; } \\
\text { - Unit } 6 \text { inset into Unit } 4 / 5 \mathrm{~m}\end{array}$ & None \\
\hline GT14 & $\begin{array}{l}\cdot 0-55 \mathrm{~cm} \text { Unit } 4 \mathrm{~s} \text { (eolian deposit? weakly to } \\
\text { noncalcareous loam) } \\
\text { - } 55-105 \mathrm{~cm} \text { : Unit } 3 \text { marl and soil formed at top of marl } \\
\text { - } 105-150 \mathrm{~cm} \text { : Unit } 1\end{array}$ & None \\
\hline GT15 & $\begin{array}{l}\cdot 0-163 \mathrm{~cm}, \text { Recent fill } \\
\cdot 163-200 \mathrm{~cm} \text { : unidentified loamy sediment. }\end{array}$ & None \\
\hline GT16 & $\begin{array}{l}\cdot 0-70 \mathrm{~cm}: \text { Recent fill } \\
\cdot 70-200 \mathrm{~cm}: \text { Unit 4/5? }\end{array}$ & None \\
\hline GT17 & $\begin{array}{l}\cdot 0-73 \mathrm{~cm} \text { : Unit } 5 \mathrm{~m} \text { floodplain facies } \\
\cdot 73-157 \mathrm{~cm} \text { : Unit } 4 \mathrm{~m} \text { floodplain facies } \\
\cdot 157-180 \mathrm{~cm} \text { : Unit } 3 \mathrm{marl}\end{array}$ & None \\
\hline GT18 & $\begin{array}{l}\cdot 0-72 \mathrm{~cm} \text { : Unit } 5 \mathrm{~m} \text { floodplain facies } \\
\cdot 73-170 \mathrm{~cm} \text { : Unit } 4 \mathrm{~m} \text { floodplain facies } \\
\cdot 170-180 \mathrm{~cm} \text { : Unit } 3 \mathrm{marl}\end{array}$ & None \\
\hline GT19 & $\begin{array}{l}\cdot 0-130 \mathrm{~cm} \text { Unit } 4 / 5 \mathrm{~m} \\
\cdot 130-160 \mathrm{~cm}: \text { Init } 3 \text { marl } \\
\cdot 160-200 \mathrm{~cm}: \text { Unit } 1\end{array}$ & None \\
\hline GT20 & $\begin{array}{l}\cdot 0-40 \mathrm{~cm} \text { : landfill spoil } \\
\text { - 40-148 cm: Unit 4s? } \\
\text { - } 148-300 \mathrm{~cm} \text { : Unit } 3 \text { marl, with buried soil between } \\
148-170 \mathrm{~cm} \text { (presumably correlative with Yellowhouse } \\
\text { Soil at Lubbock Lake) } \\
\text { - } 300-330 \mathrm{~cm} \text { : Unit } 1 \\
\cdot 330 \mathrm{~cm} \text { : Caprock Caliche }\end{array}$ & $\begin{array}{l}\text { - } 29 \text { bulk samples } \\
\text { - } 3 \text { bulk sediment/soil radiocarbon samples ( } 2 \text { from Unit } 3 \text { marsh } \\
\text { deposits, one from soil at top of Unit } 3 \text { (presumably correlative to } \\
\text { the Yellowhouse soil at Lubbock Lake) } \\
\text { - two OSL samples, one from Unit } 1 \text { at base of section, and } \\
\text { another from loamy sediment above soil formed in Unit } 3 . \\
\text { - short column of diatom samples through Unit } 3 \text {. } \\
\text { - bone }\end{array}$ \\
\hline GT21 & $\begin{array}{l}\cdot 0-80 \mathrm{~cm}: \text { Unit 4/5m } \\
\cdot 80-200 \mathrm{~cm}: \text { Unit 3(?) } \\
\cdot 200-215 \mathrm{~cm}: \text { Unit 1: } \\
\cdot 215 \mathrm{~cm}: \text { Caprock Caliche }\end{array}$ & None \\
\hline
\end{tabular}


Both bulk soil samples and bone samples are available to date Unit 6 . Two bulk sediment/soil samples were collected from the Unit 6 deposits beneath the $1.5 \mathrm{~m}$ floodplain (T0) surface in GT4. In addition, $670 \mathrm{~g}$ of animal bone fragments were recovered from $1.55 \mathrm{mbs}$ from this section as well. We proposed to date at least three samples from this trench, including the two bulk soil samples and at least one bone sample. A bone sample was submitted for radiocarbon dating from GT4 from $.85 \mathrm{mbs}$. The two bulk sediments were submitted from 1.25-1.28 mbs and 2.0-2.5 mbs.

Table 5-2. Bone from Gradall Trenches

\begin{tabular}{|c|c|c|c|}
\hline FS Number & Backhoe Trench & Depth (mbs) & Weight (g) \\
\hline 1 & GT2 & 1.35 & 5 \\
\hline 3 & GT4 & 0.83 & 20 \\
\hline 2 & GT4 & 0.85 & 42 \\
\hline 4 & GT4 & 1.35 & 38 \\
\hline 6 & GT5 & 0.5 & 5 \\
\hline $37(5)$ & GT5 & unknown & 112 \\
\hline 7 & GT10 & 0.6 & 140 \\
\hline 8 & GT10 & 0.6 & 76 \\
\hline 9 & GT10 & 0.75 & 168 \\
\hline 60 & GT10 & 0.75 & 56 \\
\hline 42 & GT10 & 1.6 & 1546 \\
\hline 61 & GT10 & 1.65 & 2922 \\
\hline 56 & GT11 & 0.64 & 158 \\
\hline 56 & GT11 & 0.64 & 176 \\
\hline 55 & GT11 & 0.71 & 1263 \\
\hline 12 & GT11 & 0.85 & 64 \\
\hline 11 & GT11 & 1.03 & 597 \\
\hline 10 & GT11 & 1.1 & 472 \\
\hline 57 & GT11 & 1.21 & 97 \\
\hline 14 & GT11 & 1.35 & 38 \\
\hline 17 & GT11 & 1.4 & 11 \\
\hline 13 & GT11 & 1.45 & 148 \\
\hline 16 & GT11 & 1.45 & 647 \\
\hline 15 & GT11 & 1.55 & 670 \\
\hline 59 & GT11 & backfill & 17 \\
\hline 41 & GT11 & backfill & 13 \\
\hline 43 & GT20 & 0.95 & 54 \\
\hline 40 & GT20 & backfill & 14 \\
\hline
\end{tabular}

\section{Theme 2: Late Quaternary Paleoenvironments of Running Water Draw}

There are almost no data on Unit 3 habitats beyond Mustang Springs (Meltzer 19991) and no data on the newly discovered Unit 5 channel related wetland facies. From the ubiquitous bison bone and contorted strata associated with the Unit 5 channels, it seems clear that the latter deposit was a well visited water hole, probably similar to the one Sellards et al. (1947) speculate was present during the Plainview Site occupation. Winsborough (1995) examined diatoms from a number of sites in draws across the Southern High Plains, but primarily focused on the Unit 1 and Unit 2, organic-rich, non-calcareous pond-marsh environments. Analysis of the diatom samples recovered from contexts sampled within selected portions of Running Water Draw will contribute new information to our understanding of Late Holocene water quality, and given the ubiquity of bone in these deposits, it is likely that at some point a site will be found in this stratigraphic context. The comparative baseline data from Units 1 and 2 will provide a contrast to the Unit 5 data and will help to document the nature of paleoenvironmental changes between the late Pleistocene and late Holocene.

\section{Available Data Types}

Two short columns of diatom samples were collected in the field from the Unit 5 channels (one each from GT10 and GT11) and one each from Units 1 and 3 in GT20. The two short columns consisting of 22 individual samples from the Unit 5 channels should show the same trend, if these deposits in the two trenches are contemporaneous, as they were thought to be in the field. Examination of the diatom assemblage from these Unit 5 deposits should provide an image of water quality much later in the Holocene, and provide new information, given that Holliday has not seen or recognized this facies. Given that Winsborough's baseline data associated with deposits dating to Unit 1 already exists, we proposed only the analysis of the 22 individual samples from the Unit 5 channel deposits. These were submitted to Dr. Barbara M. Winsborough of Winsborough Consulting.

\section{Theme 3: Age and Stratigraphic Context of the Plainview Site}

The age and stratigraphic context of the Plainview Site have been the source of considerable speculation since Sellards et al. (1947) reported the results of their excavations in the Bulletin of the Geological Society of America. This is in part due to the nature of the brief descriptions provided by Sellards et al. (1947) and complicated by lateral facies changes that occur within the draws, the general nature of which have recently been documented by Holliday (1990; 
1995). Sellards et al. (1947:936) describe the stratigraphy at the bone bed as follows:

The fill consists of a basal zone of cross-bedded sands and water-worn caliche gravels from a few inches to 3.5 feet thick, an intermediate zone of massive compact sandy clay 5 to 8 feet thick, and an upper zone of dark sandy soil 1.5 to 3 feet thick.

They further noted that they thought the bone accumulated in a shallow water hole or a pond within the former channel of the draw and that shallow water was indicated

by the thin layer of pond sediment with broken and poorly preserved bones in the upper part and by the presence of fresh-water invertebrates... Lymnea, Physa, Helisoma species are all pulmonates and are usually found living in shallow water pools and ponds [Sellards et al. 1947:934].

The first person to re-examine the local stratigraphy of the site following Sellards et al. (1947) was Eddie Guffee during excavations in 1976-1977. Guffee was commissioned by the City of Plainview to relocate the site and determine its boundaries. In pursuing these goals, Guffee excavated $45 \mathrm{~m} 2$ from the bone bed and recovered the fragmentary remains of no more than 17 bison. Given the nature of the recovered material, Guffee's work concentrated on the faunal material, and the stratigraphic column recorded was basic (Guffee 1979:41; Figure 1). When Guffee examined our Trench 20 , which is the closest exposure to his (he estimated it to be about $30 \mathrm{~m}$ from his block), he noted that it "does not look like what I excavated." In particular, Guffee noted that there was a lot of "blow sand" or what he referred to as "the altithermal dune sand" in his excavation that was not present in ours. It is not clear how much of this is the blur of time, or a reflection of dramatic lateral facies changes within the draw deposits (see discussion below). His stratigraphic column recorded five distinct deposits that are clearly derived from the Sellards et al. (1947) description:

\section{1) Panhandle Formation caliche,}

2) Basal zone of cross-bedded sands and gravels that contained the bone bed,

3) Intermediate zone of massive compact sandy clay,
4) An upper zone of dark sandy soil, and

5) A machine deposited fill from the caliche quarry.

Guffee's observations on the location and context of the Plainview Site bone bed were less problematic, with the bone recovered from the cross-bedded sand and gravel immediately above the Ogallala Formation caliche. He noted that this paleochannel deposit was associated with a stream that flowed from southwest to northeast, and that the transverse orientation of the bones suggests that they had been moved somewhat by the stream.

Starting in 1985, Vance Holliday documented the exposures revealed by two caliche pits located in proximity to the Plainview Site, which he refers to as Pits 2 and 3. Pit 1 was the excavation that revealed the original Plainview Site and was located between the right bank of the present channelized stream and Joliet Street to the west, immediately west of GT20. It is now completely filled with trash. In 1985, Holliday published a paper that described and analyzed a profile from the north end of the western wall of Pit 2 . The examined profile was situated almost directly across the rectified channel of Running Water Draw from the site. In 1990, Holliday documented the stratigraphy revealed by the long north-south running western wall of Pit 3 , which is still visible today behind the cemetery on Joliet Street. This profile (Holliday 1995:45, Figure 26b) nicely illustrates the lateral facies variation present along the southern valley margin and provides some evidence to support Guffee's comment with respect to local lithologic variation within the valley floor deposits. Indeed, in this profile Holiday documented a wedge of eolian sand encroaching on the draw floor from the adjacent upland that is the lateral equivalent of the marl (Unit $3)$.

Given the degree of local lithologic variation within the valley floor documented by both Holliday and Guffee, we recommended the analysis of the samples collected from GT20, which is the nearest anyone has come to the Plainview Site since Eddie Guffee's excavations and it may be the best example of the remaining stratigraphy in the vicinity of the site. This trench was cut into the edge of the modern rectified channel of Running Water Draw and revealed Unit 1 (crossbedded sands and gravel within which the Plainview bone bed was situated) and more than a meter of Unit 3 marl (carbonate rich, pale greenish gray (2.5Y hue) sandy and loamy sediment that contained numerous aquatic snails and clams). The Unit 3 deposits are recorded by Holliday (1995:32) as being up to 10,000 years old, and the stage II calcic horizon exhibited by the soil formed within marl may imply an older age in this exposure than in others observed during the fieldwork. 


\section{Available Data Types}

Three bulk sediment radiocarbon samples, a bone fragment, and two OSL samples were collected from this exposure for dating purposes. Of the two OSL samples collected from this trench, one is from Unit 1, for which there is a poor chronology, and the second is from the sandy sediment above the paleosol at the top of the Unit 3 marl. Despite having been poorly dated, the Unit 1 sands were the matrix within which the Plainview Site resided. The chronology for the Plainview Site and the nearby Pit 3 quarry face, reviewed in detail by Holliday (1997:105), has yielded a wide range of ages making the actual age of the event a source of some speculation (Holliday 1997:109-110). Dating the Unit 1 OSL sample may yield new information on the age of the Plainview Site. Dating of the Unit 3 marl will indicate whether this deposit is significantly later as was suggested by Holliday from dates he obtained at Pit 3, or closer in age to the Unit 1 sand. Dating Unit 3 here will permit a firm bracket for this deposit in Running Water Draw, rather than the single date Holliday has obtained from Pit 3, $200 \mathrm{~m}$ downstream of the site. These two samples were submitted to the Sheffield Centre for International Drylands Research.

To coincide with OSL dating, we recommended the performance of basic physical characterizations on the 29 sediment samples collected from this profile (i.e. granulometry, organic carbon and calcium carbonate content). These analyses were performed by Dr. Charles Frederick.

In addition to these analyses, we recommended having the 16 individual diatom samples from Units 1 and 3 analyzed. On lithologic grounds, the water quality associated with Units 1 and 3 appears to be different, but whether this was significant or not to local fauna is unknown. Analysis of the column from GT20 may enhance our understanding of Holocene wetland environments associated with Running Water Draw by contrasting the Unit 1 channel (presumably directly related to the Plainview Site) and Unit 3, which is the marl overlying Unit 1. A significant lithologic change occurs in this interval and this presumably is attributable, at least in part, to a change in water quality. The lowest two samples presumably will directly relate to water quality at the time of the Plainview occupation. These were submitted to Dr. Barbara M. Winsborough of Winsborough Consulting.

Finally, at the time of the fieldwork, we questioned Eddie Guffee about any curated sediment samples from his site excavation. He could not remember but indicated that if he did collect samples, they would be located in the Museum of the Llano Estacado at Wayland Baptist University. We recommended a brief search through the curated materials housed at the Museum of the Llano Estacado to determine if such samples exist. CAR recommended the characterization of the deposits in a fashion similar to GT20 if such a sediment column was located. On December 6, 2006, two archeologists from CAR- UTSA visited the Llano Estacado Museum.

No soil samples from the 1976 excavation were located. Rather, soil samples were found from a 1974 survey conducted along the Running Water Draw, approximately 4 miles west of Plainview. These samples were collected from the same draw on which 41HA1 is located. Processing these soil samples as a comparative base to the samples collected from the 2005 survey conducted by CAR can provide additional data relevant to Running Water Draw. The Running Water Draw samples were not brought back to San Antonio, but are in a location now in Guffee's office that is easily accessible.

Other resources encountered and brought back include two reports. One is the 1974 report concerning the Survey of the Running Water Draw Watershed Survey by Jack Hughes and Eddie Guffee. The other is the 1993 report by Eddie Guffee and Vance Holiday concerning the archeological investigations of the Plainview Regional Landfill. Guffee also lent CAR the original photos of the 1976 trenching at 41HA1 to be scanned and returned for housing at the Llano Estacado Museum. 


\section{Chapter 6: Results of Geoarcheological Survey Trenching and New Observations on the Late Quaternary Stratigraphy of Running Water Draw}

This chapter summarizes the results of geoarcheological investigations performed in association with the survey of the Hike and Bike Trail. Because much of the trail is situated upon the Holocene valley floor of Running Water Draw, and the draws on the Southern High Plains have a well-documented history of harboring buried archeological sites, where the trail was thought to be situated upon Holocene sediments, the deposits were trenched with a Gradall.

Twenty-one trenches were excavated in the right-of-way of the Hike and Bike Path between Broadway Park and Running Water Draw Regional Park. Many of these trenches were about $1.5 \mathrm{~m}$ deep, but several were excavated deeper to explore specific stratigraphic issues. In the case of the stream crossings, the trenches were placed on the sloping margin of the draw channel where grading associated with the path were anticipated to impact deposits at greater depth (e.g. at crossing 1, 2, 3 and 4 (near 41HA1)). When trenches were placed into the sloping edge of the channel, they were benched in a fashion that permitted examining a long profile in two or three short sections.

In addition to the geological study, an archeological pedestrian survey including mechanical auger boring and surface inspection were conducted along the path of the hike and bike trail. The results of the archeological survey are discussed followed by the results of the geological studies.

\section{Archeological Survey Results}

Most of the project area was covered in grass with visibility ranging from $0 \%$ to $50 \%$. The western and eastern ends of the project, where Running Water Draw Regional Park and Broadway Park are located, have been landscaped and are almost entirely covered with grass. Visibility in both park areas was limited to bare spots and areas around trees (Figure 6-1). The project area from Columbia Street to Quincy Street had an average visibility of $50 \%$ or more in the areas along the channel of Running Water Draw. This area also included a landfill area stretching from Columbia Street to Joliet Street next to the recorded location of the Plainview Site (Figure 6-2). The area from Quincy Street to Ennis Street consisted entirely of urban development with visibility ranging from $0 \%$ to $30 \%$. Parts of the hike and bike trail ROW where staked next to the street pavement, private landscaped areas, and parking lots. The Plainview Country Club spans the area immediately east of Ennis Street. A wide variety of modern disturbances were observed along this stretch of the project area including the ones mentioned previously, as well as a variety of underground utilities. Figure 6-3 shows the area between Quincy Street and Ennis Street affected by urban development.

Fifty-five auger tests (AUs) were dug along the project ROW, one every $100 \mathrm{~m}$ (Figures 6-4a-6-4d). The only area of the project were no auger holes were dug was the stretch extending from Quincy Street to Ennis Street. These areas have been highly disturbed by urban development and installation of utility lines. Furthermore, the presence of gas, electrical, and other utility lines would compromise the safety of the individuals performing the auger testing as well as that of those living in the surrounding area. Auger tests were also dug within both Running Water Draw Regional Park and Broadway Park, given the possibility of some undisturbed deposits. No mechanical augering was performed in the immediate vicinity of 41HA1 since it is a National Historic Landmark.

Six auger tests were dug in the area east and west of Joliet Street where the tree removal area was marked by TxDOT staff (Figure 6-5). Only two auger tests were dug in the east side of Joliet Street because the area appears to have been disturbed by the landfill and the construction of the road, a sewer line running underneath the street, and a gas line. These auger tests were dug about 3-5 $\mathrm{m}$ from the actual tree line to avoid the gas line along the east side of Joliet Street. In addition, given information provided by Randy Woods, Plainview Maintenance Supervisor, there is an irrigation/ sprinkler system installed underneath the root system of the trees. Placement of this irrigation system may have also disturbed the area. The remaining four auger tests were dug in the western side of Joliet Street, 3-5 m away from the tree line to avoid the irrigation system. The west side of Joliet Street does not appear to be have been disturbed by nearby development and construction activities.

Auger tests were also performed at intervals less than $100 \mathrm{~m}$ in the vicinity of site $41 \mathrm{HA} 12$. Ten auger tests were excavated between the recorded location of 41HA12 and GT 5. These were dug in the centerline of the trail ROW and subsequently expanded to the northwest. No auger tests were excavated within the channel of Running Water Draw due to limited access and safety concerns associated with the sloping surface. All auger tests were located within the hike and bike trail ROW. 


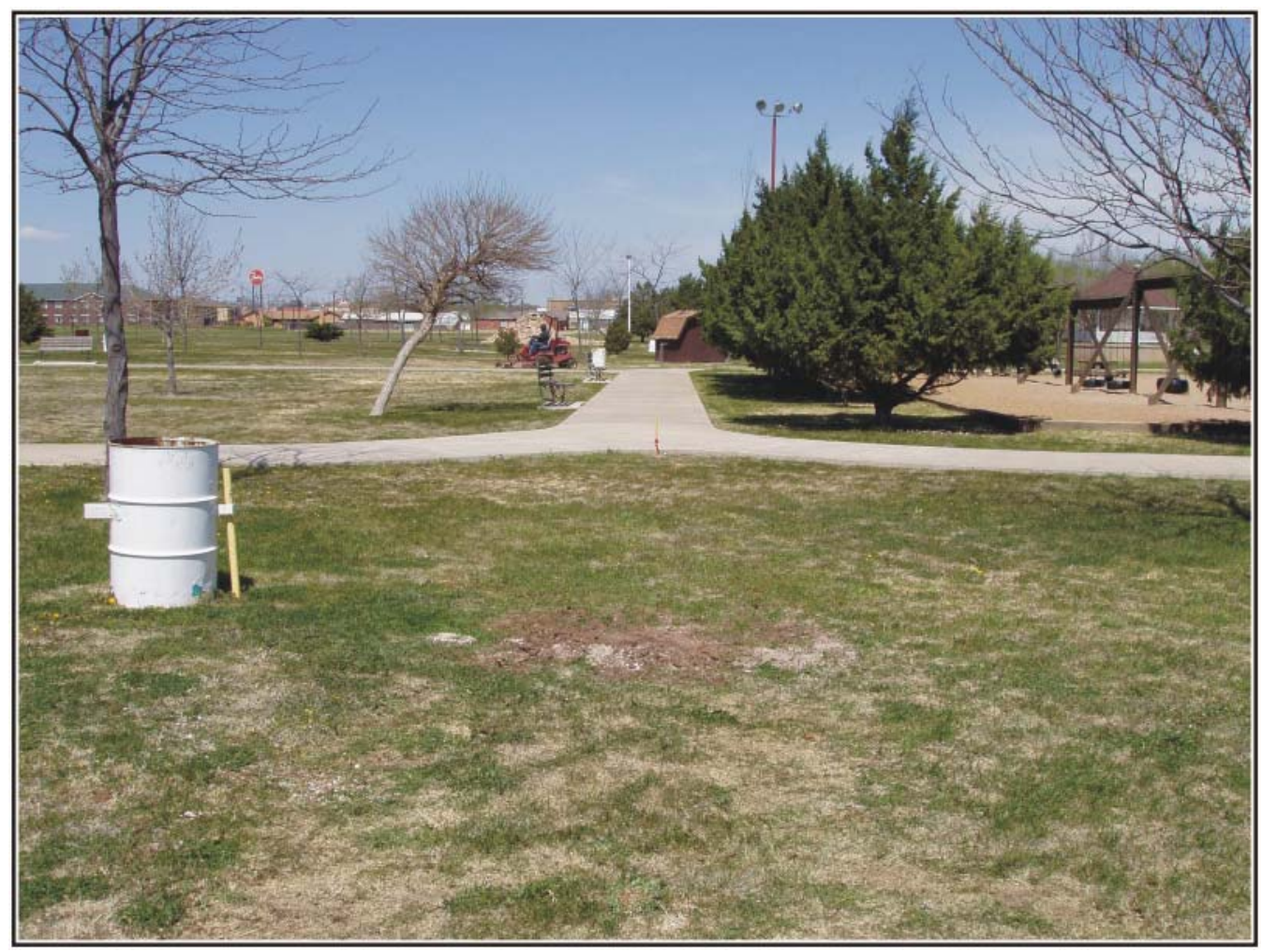

Figure 6-1. Landscaping at Running Water Draw Regional Park.

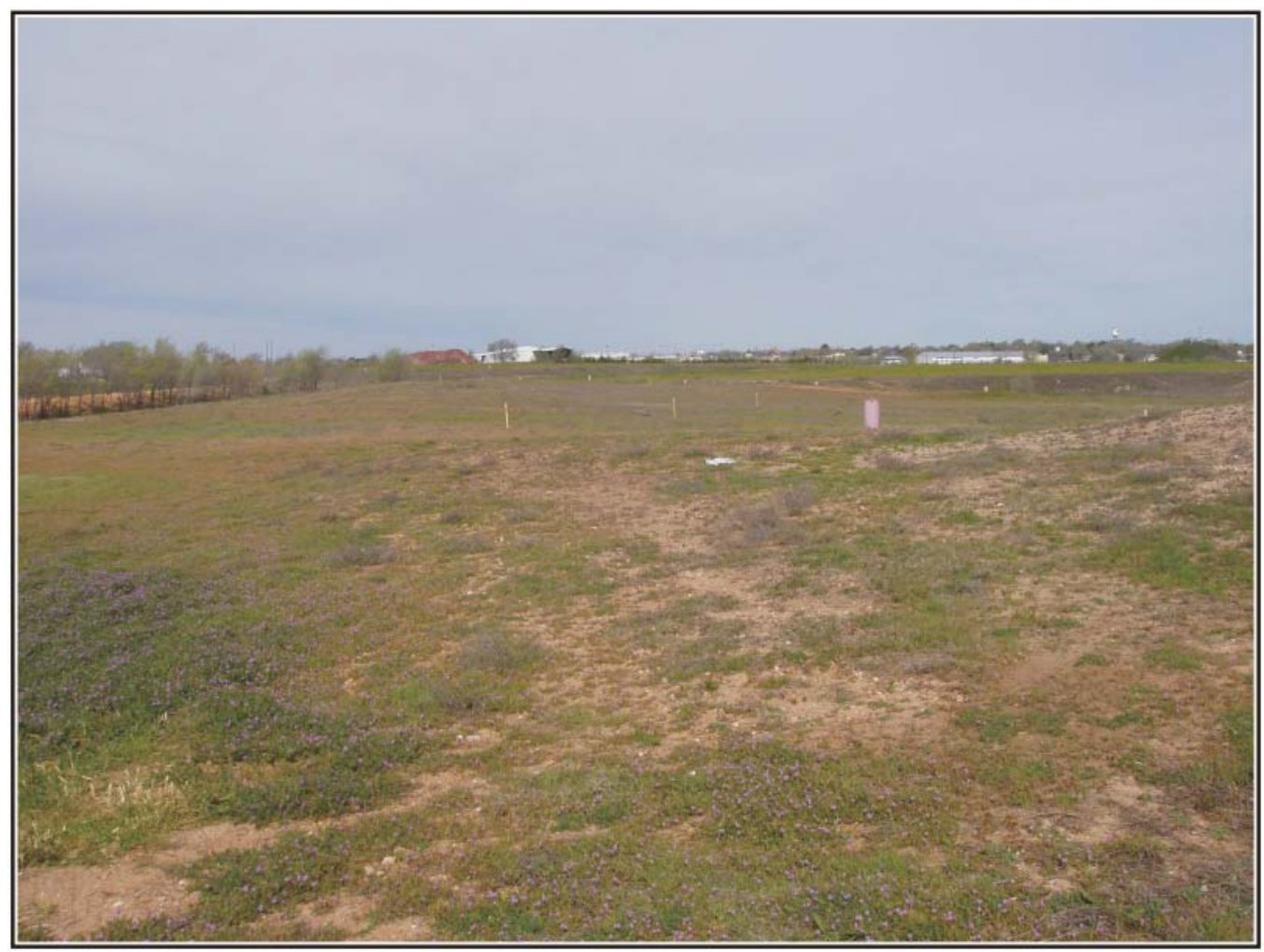

Figure 6-2. Landfill in the vicinity of site 41HA1. 


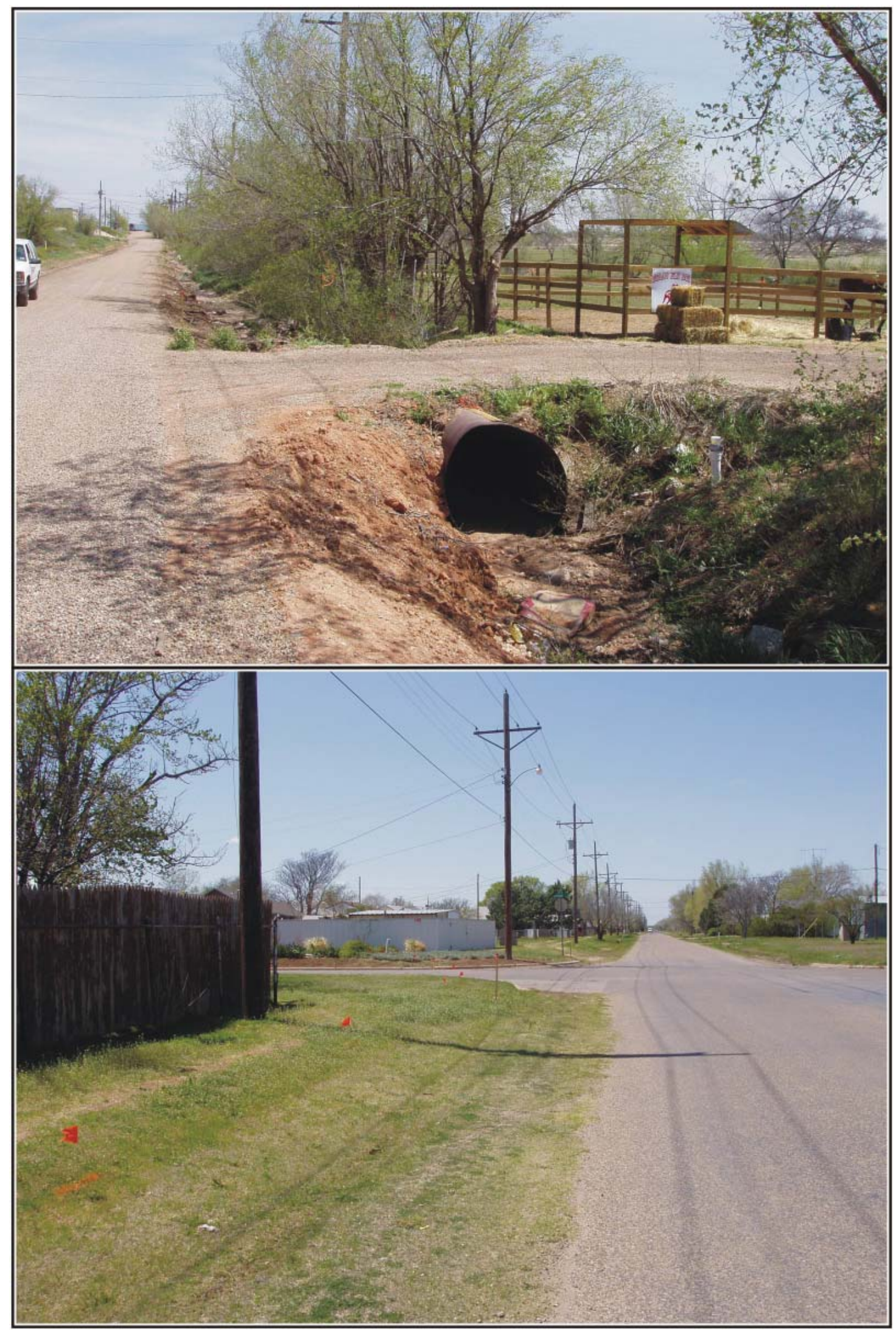

Figure 6-3. Disturbed areas along proposed hike and bike trail between Quincy and Ennis Streets. 


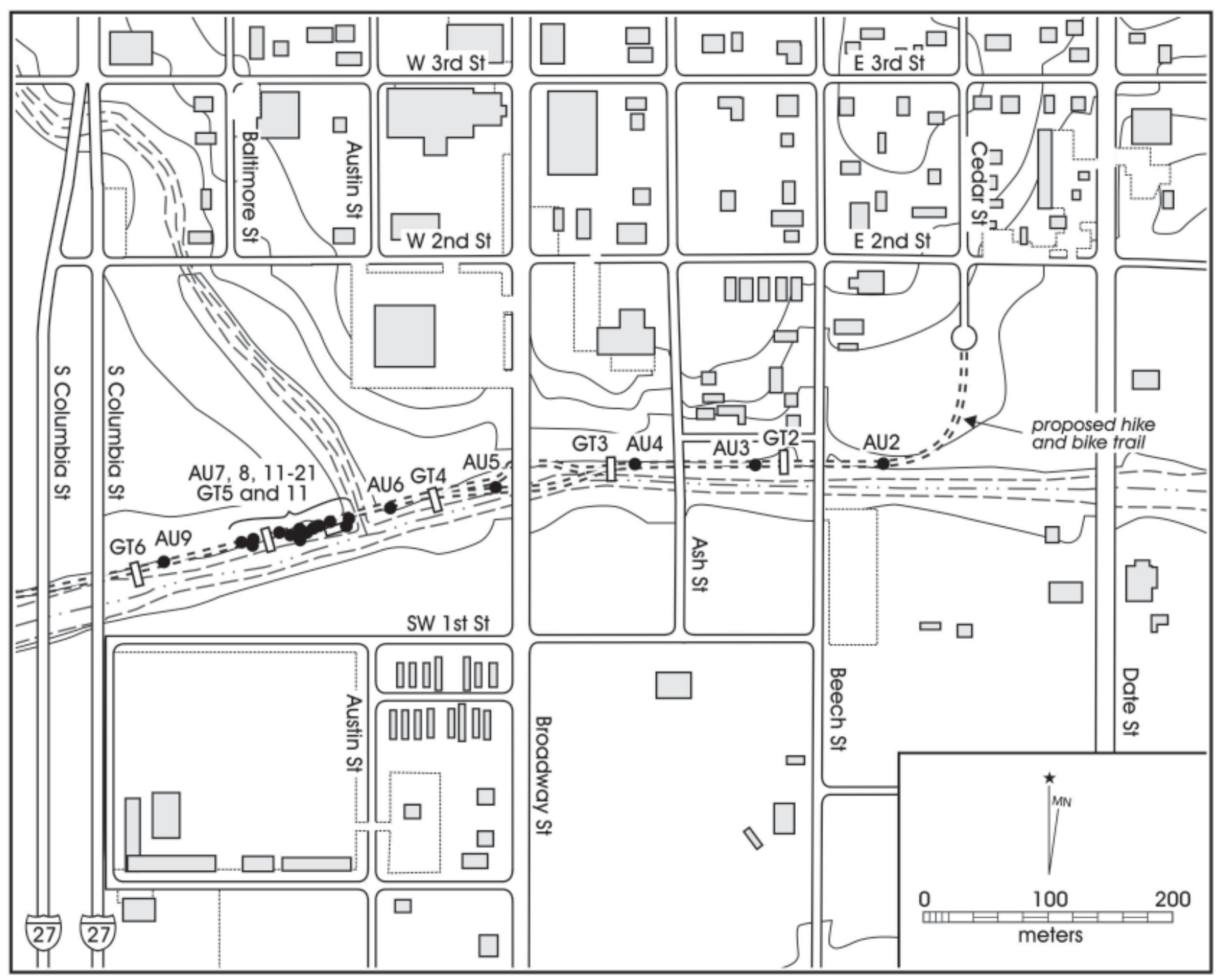

Figure 6-4a. Locations of auger tests and Gradall trenches along eastern end of project ROW from Cedar Street to S. Columbia Street. 


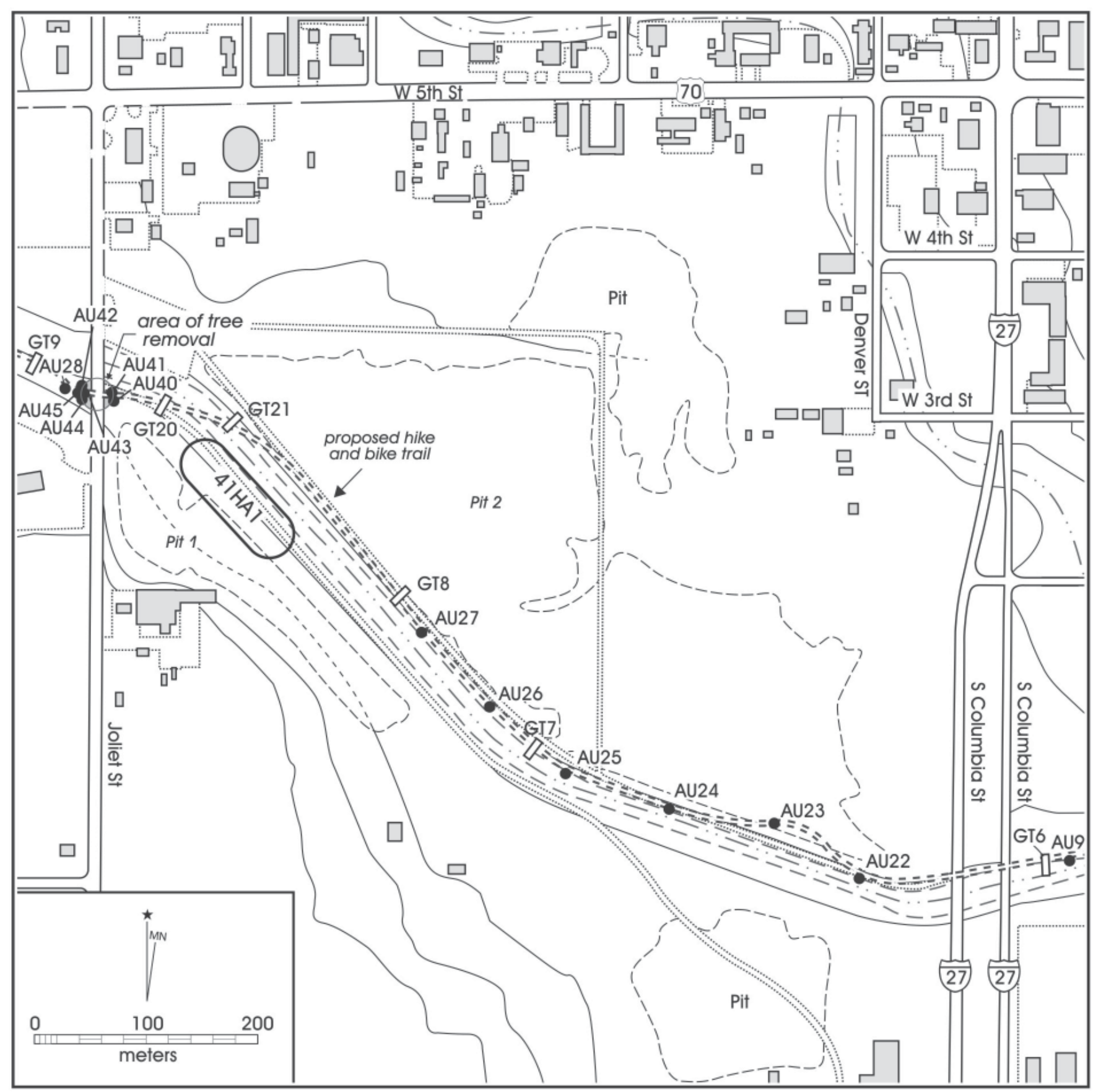

Figure 6-4b. Locations of auger tests and Gradall trenches along project ROW between Columbia Street and Joliet Street. 


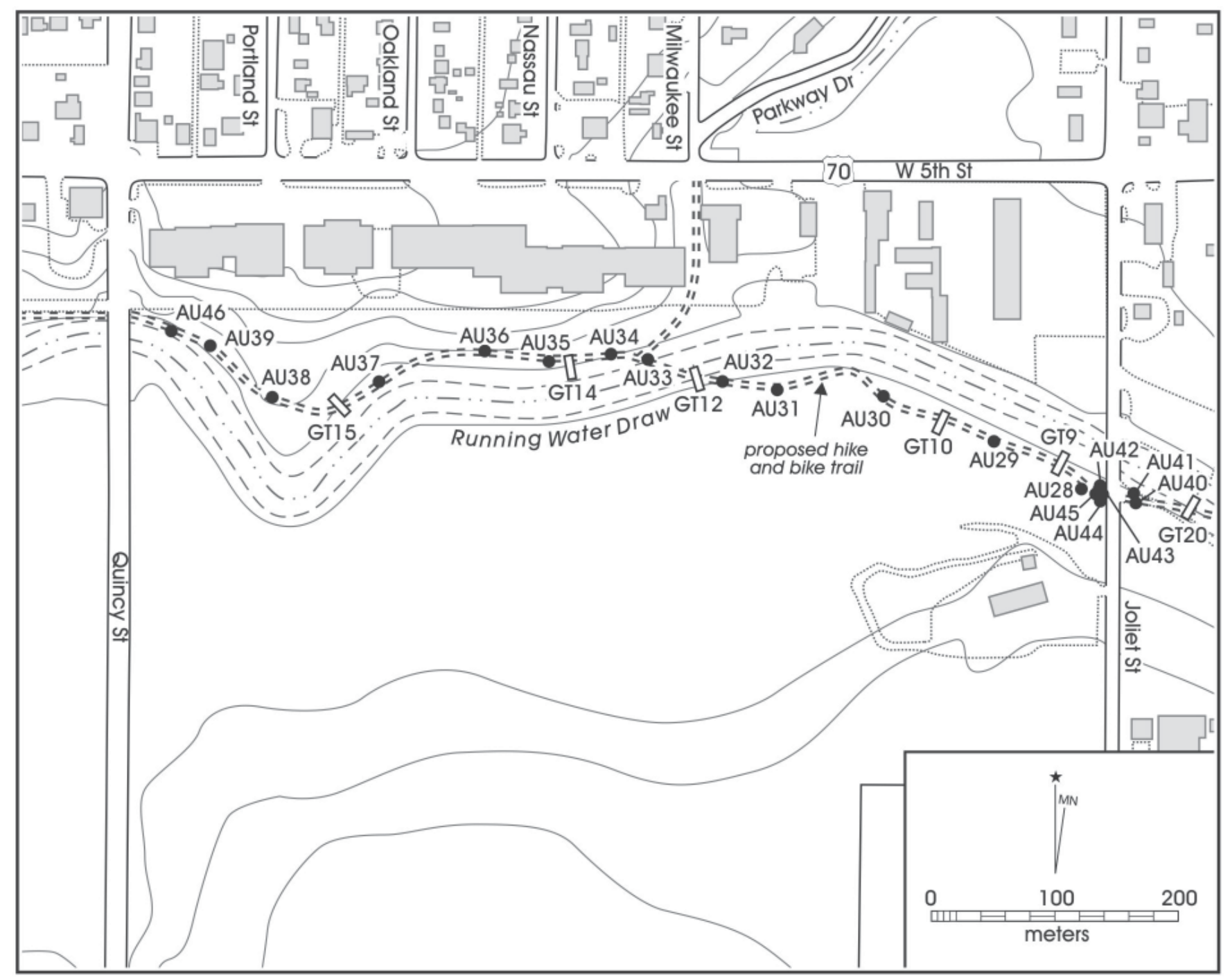

Figure 6-4c. Locations of auger tests and Gradall trenches along project ROW between Joliet Street and Quincy Street. 


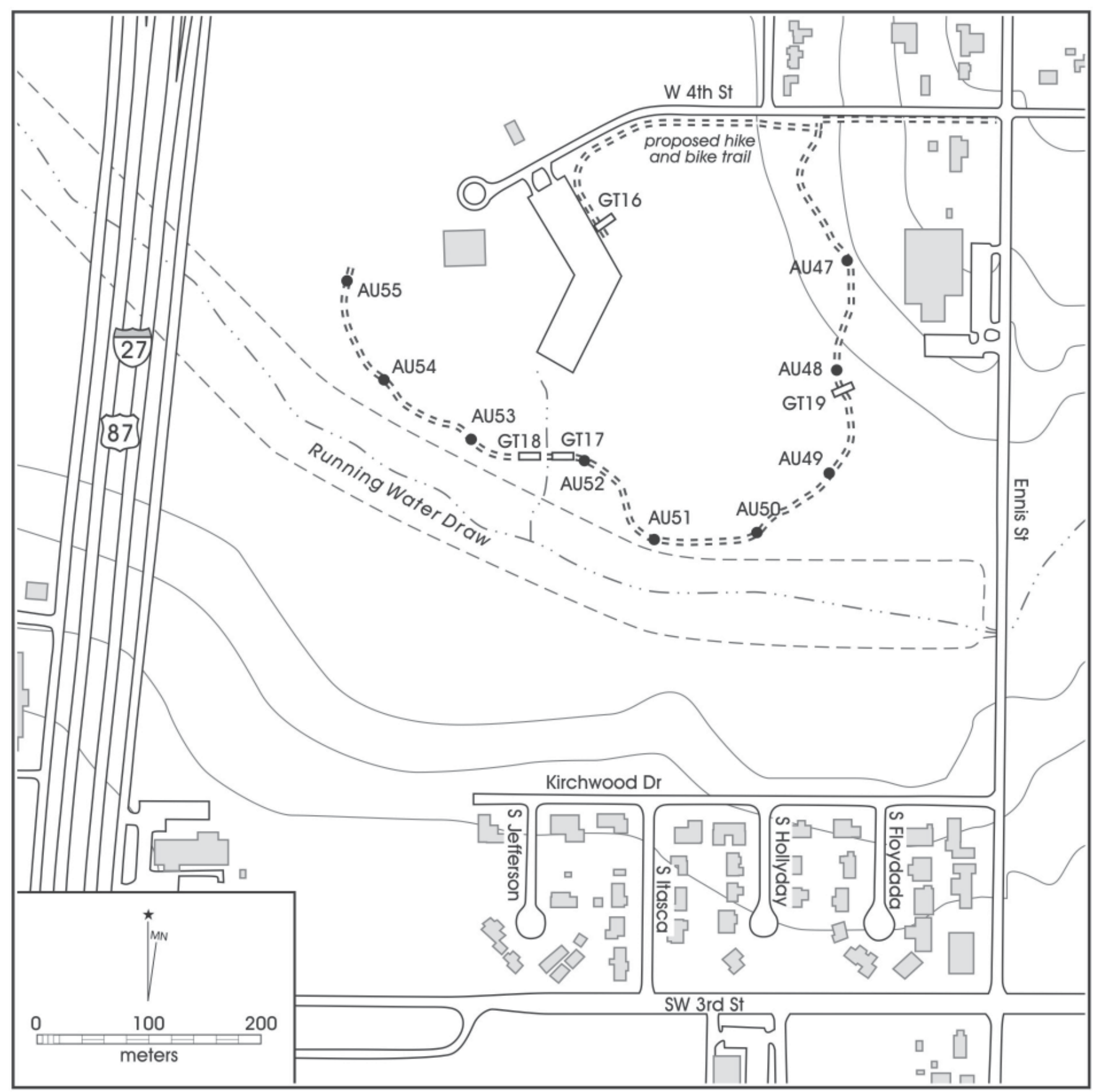

Figure 6-4d. Locations of auger tests and Gradall trenches along western end of project ROW (in Running Water Draw Regional Park) between Joliet Street and Quincy Street. 


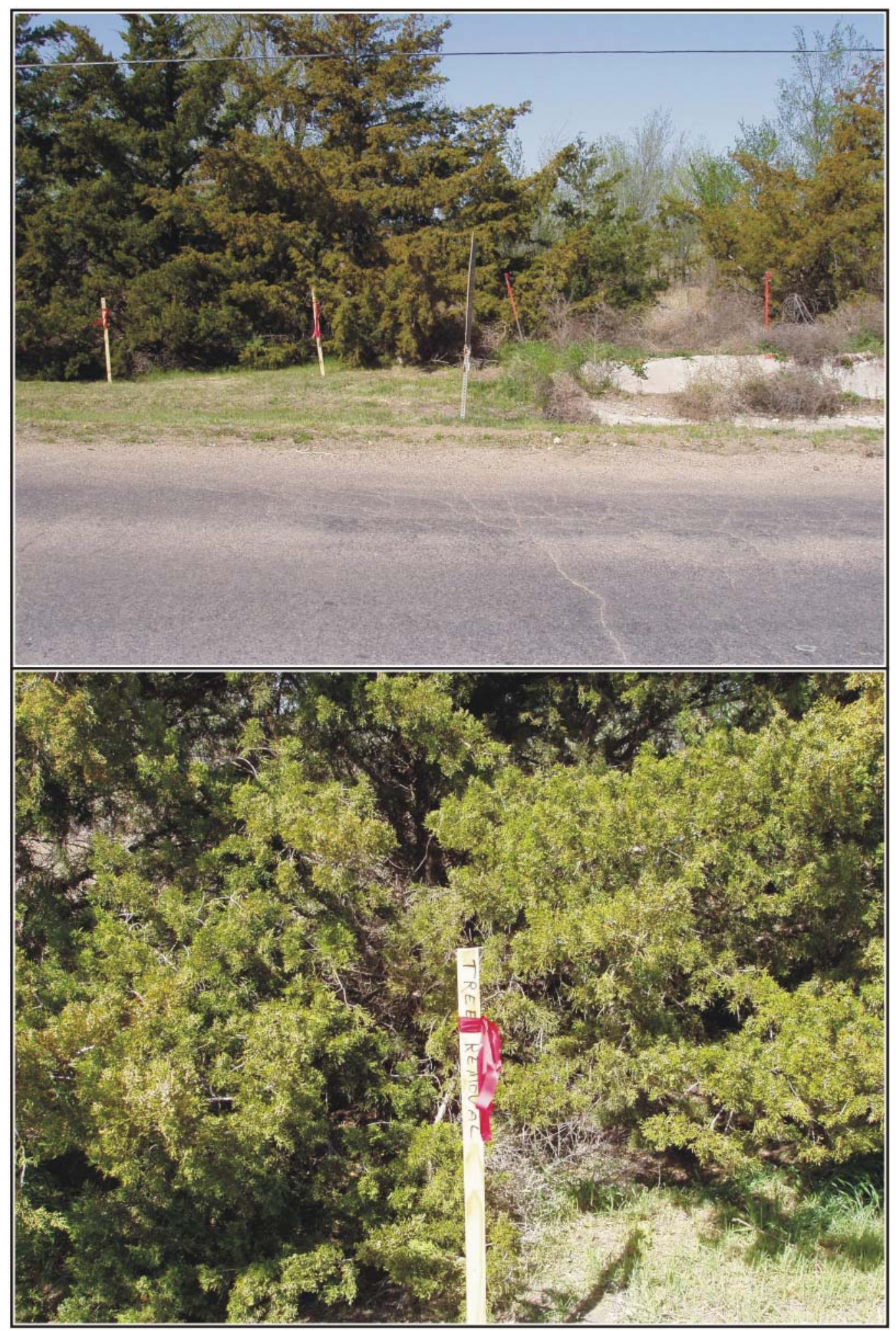

Figure 6-5. Area of tree removal along proposed hike and bike trail. 
The landfill area extending from Columbia Street to Joliet Street was auger tested even when some of the area appeared heavily disturbed. Geological examination performed before the auger testing suggested that the southern part of the landfill closer to Running Water Draw contained some undisturbed deposits. Based on this information, some of the auger tests were located as close as possible to the draw at a safe distance from the slope. All auger bores were located within the marked project ROW.

The recorded location of site $41 \mathrm{HA} 12$ was tested by digging 10 auger tests. We were unable to locate the site datum, which is reported right next to the telephone pole in the intersection of the old channel and Running Water Draw, according to the information in the Texas Archeological Sites Atlas (Figure 6-6). Four of the auger tests (AUs 11, 16, 18, and 19) produced materials similar to the ones described by Thoms: a few small fragments of coal, one very small piece of charcoal, and a small piece of red sandstone. The charcoal fragment appears to be modern and the sandstone fragment does not appear to be burnt. Once the mechanical augering was completed near $41 \mathrm{HA} 12$, a trench (GT11) was excavated as close as possible to the old channel north of the project centerline. This trench confirmed

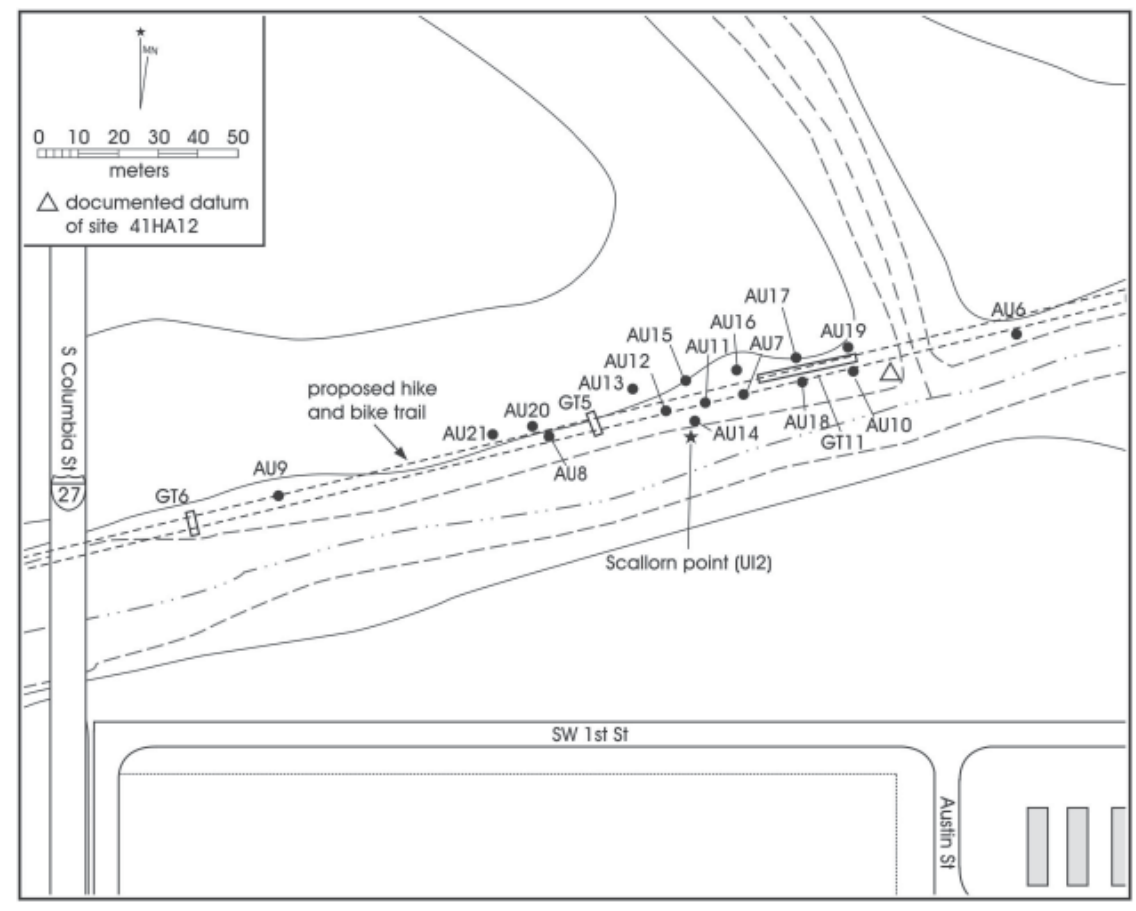

Figure 6-6. Map showing location of Scallorn point recovered west of site datum for 41 HA12.
Thoms' (THC 2005) report that the deposits at site 41HA12 are the product of recent alluvial deposition. No further work is recommended at this site.

Twenty-one Gradall trenches were dug within the project area route (Table 6-1). Originally, one Gradall trench was intended to be located every $200 \mathrm{~m}$ between Thomas Boulevard and Columbia Street, two on each bank of the water crossings including the location of 41HA1 and two additional Gradall trenches northwest and southeast of the site limits of 41HA1. Based on the disturbances present within the project area and the observations made by the geoarcheologist and

Table 6-1. Location of Gradall Trenches Excavated during Fieldwork

\begin{tabular}{|c|c|}
\hline Segment & Trench Numbers \\
\hline Broadway Park & GT1, GT2, GT3 \\
\hline Broadway to Columbia Avenue & GT4, GT5, GT6, GT11 \\
\hline Columbia to Joliet & GT7, GT8, GT20, GT21 \\
\hline Quincy to Joliet & GT9, GT10, GT12, GT13, GT14, GT15 \\
\hline $4^{\text {th }}$ Street & None \\
\hline Running Water Draw Regional Park & GT16, GT17, GT18, GT19 \\
\hline
\end{tabular}

project archeologist, Gradall trenches were only located in those areas that had the most potential to provide relevant information and that had higher potential for undisturbed deposits. Gradall trenches were also located within the boundaries of both the Running Water Draw Park and the Broadway Park due to the likelihood of finding intact deposits and the proximity to Running Water Draw.

Only two trenches were dug in the immediate vicinity of the Plainview Site, on opposite banks of the water crossing location (Figure 6-4b). The geoarcheologist and project archeologist determined that additional trenches near the Plainview Site would not provide any more information than that offered by GT 20. Additional trenching could affect areas that contain deposits associated with the Plainview Site and its Paleoindian component.

Faunal material, mostly bone from a large mammal, possibly bison, was observed in some of the trenches (GTs 2, 4, 5, 10, 11, and 20; see Figure 6-4a-c). One piece of 
bone was found in the north wall of GT2 at $135 \mathrm{~cm}$ below surface. No cultural material was observed. The presence of an old water pipe suggests that this area may have been disturbed. Trenches 4 and 5 also contained bone fragments, and tooth fragments from a large mammal were observed in the backdirt pile of GT5. No cultural material was observed in the walls of any of the trenches or the backdirt inspected. A similar situation was observed in GTs 10 and 11. These contained multiple bones from large mammals including vertebrae, skulls, and long bones. One bison skull was recovered from GT11 and two from GT10 (see Figures 6-4a to $6-4 \mathrm{c}$ for trench locations). No cultural material was observed in the walls of any of the trenches or the backdirt inspected, therefore, it is assumed that these finds represent natural deaths and no additional work is recommended in their vicinity.

The pedestrian survey along the entire length of the project area did not locate any new archeological sites within the hike and bike trail ROW. However, an isolated find consisting of an Alibates Scallorn projectile point was recovered from the surface (Figure 6-7). Scallorn points date to the Ceramic Period (i.e., Late Prehistoric), to ca. A.D. 700 to A.D. 1200 (Turner and Hester 1985). The projectile point was located in the north bank of Running Water Draw, about $150 \mathrm{~m}$ west of Columbia Street and $25 \mathrm{~m}$ from GT5. The point was found about $7 \mathrm{~m}$ off the ROW centerline (Figure 6-6). No additional cultural material was observed in the vicinity to suggest the presence of an archeological site. Furthermore, GT5 did not provide information to suggest the presence of cultural features or buried deposits. No additional work is recommended in this area.

\section{Geological Fieldwork Results}

\section{Geomorphology of Running Water Draw}

Although the Running Water Draw valley has been significantly altered by modern activities, there appear to be several clear geomorphic features. The modern draw, where it has not been channelized, exhibits a low, narrow floodplain surface that lies about $1 \mathrm{~m}$ above the channel floor. The floodplain is inset below the first terrace, which forms a broad surface that comprises the majority of the valley floor. In the reach between Milwaukee and Broadway Streets, Running Water Draw flows in a relatively straight segmented artificial channel that was apparently excavated sometime before the Plainview Site was discovered in the middle 1940's as it appears on Sellards et al. (1949) map of the Plainview Site excavations. Although we could find no information on this channel, its proximity to the point where the draw approached downtown Plainview suggests that the channel was constructed for flood control purposes. In this reach, the geomorphic relationships between the draw channel and the first terrace are modern and bear no geomorphic or stratigraphic significance.
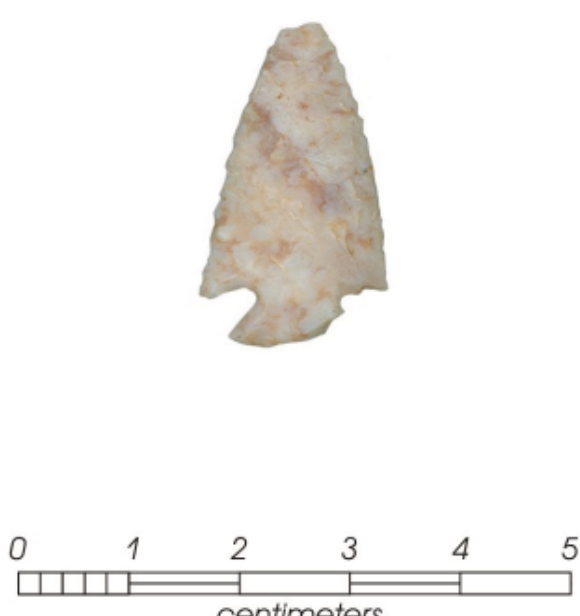

centimeters
Adjacent to the modern channel, the first terrace rises about two meters above the channel floor, but this surface appears to gradually rise away from the channel to an elevation of about $3 \mathrm{~m}$ towards the valley margin. Nearly all of our trenches were situated on the first terrace.

South of the draw channel between Amarillo Street on the west and Quincy Street on the east there appears to be an abandoned channel of the draw that extends slightly more than a kilometer south of the modern channel. We did not investigate this feature as it was not crossed by the Hike and Bike path right-ofway, but we mention it because this kind of feature may provide additional information on the Late Pleistocene history of the draws in the future.

Figure 6-7. Scallorn point recovered from surface. 


\section{Overview of the Survey Trenches}

The deposits exposed by the trenches were, in general, easily ascribed to Holliday's lithostratigraphic sequence (see Table 6-2) with three exceptions: 1) Unit 5 incised channel deposits; 2) sediments associated with the modern draw channel; and 3) modern anthrogenic fills. Each of these deposits will be discussed in some detail below. A few comments should be made on the deposits that readily fit Holliday's lithostratigraphic sequence prior to discussions of those that do not.

Table 6-2. List of Trenches Where Different Lithostratigraphic Units were Observed

\begin{tabular}{|c|c|}
\hline Stratum & Trench \\
\hline Caprock Caliche & $11,20,21$ \\
\hline 1 & $6,11(?), 12,13,14,19,20,21$ \\
\hline 2 & Not observed \\
\hline 3 & $3,6,12,14,17,18,19,20,21$ \\
\hline 4 & $2,5,9,10,11,14,17,18,20$ \\
\hline 5 & $2,4,5,9,10,11,17,18$ \\
\hline $4 / 5$ undifferentiated & $3,6,7,12,13,16,19,21$ \\
\hline Modern floodplain & $4,11,13$ \\
\hline Fill \&/or Disturbed & $1,2,3,4,7,8,15,16,20$ \\
\hline unknown & 8,15 \\
\hline
\end{tabular}

Figure 6-8 provides a visual summary of the deposits of Running Water Draw observed during this work. Although there are some lateral variations in the draw deposits such as Holliday has documented in Pit 3, much of the draw deposits are simply superimposed one upon another in a layer cake fashion. As a result, most trenches exposed more than one lithostratigraphic unit. The most common deposit observed during trenching was Stratum 3, which occurred in almost half of our trenches. Its light color and elevated carbonate content render it easily identifiable. Strata 4 and 5 , and the catchall $4 / 5$ were almost as common, and if considered collectively, were easily the most ubiquitous deposits encountered. Given that they represent the most recent deposits, this is to be expected. However, as Holliday
(1995) describes, there appeared to be considerable lithological/stratigraphic variation in these strata.

\section{Stratum 5 and Modern Channel Deposits}

As noted above, we observed three deposits that were not well represented in Holliday's work on Running Water Draw. Perhaps the most significant of these were a series of incised channels of Running Water draw associated with Stratum 5. We observed these deposits in three different trenches, specifically 4,10 , and 11 , where the depth of the incision and nature of the deposits was somewhat variable. In general terms, these channels were cut from the first terrace into underlying deposits (generally Stratum 4) and filled with sand and loamy sediments that clearly demonstrated the presence of flowing water. Two of these incised channels (Trenches 10 and 11) yielded numerous bison bones and apparently contained enough water to serve as a water source for bison and other inhabitants. It was clear in the field that these deposits did not fit well into Holliday's lithostratigraphy, so we radiocarbon dated material from each trench in order to understand how these features related to one another.

In the final analysis, it appears that there are three distinct channel assemblages associated with Stratum 5, two that are of Late Holocene age (Groups A and B), and a modern/ Historic age channel (Group C). In the field, we recognized two channel groups, one that was shallowly incised below the first terrace surface and a second beneath the modern floodplain. But as is described below, our observations, when combined with Holliday's Quincy Street observation made it clear that there were actually three: Group A, Group B, and

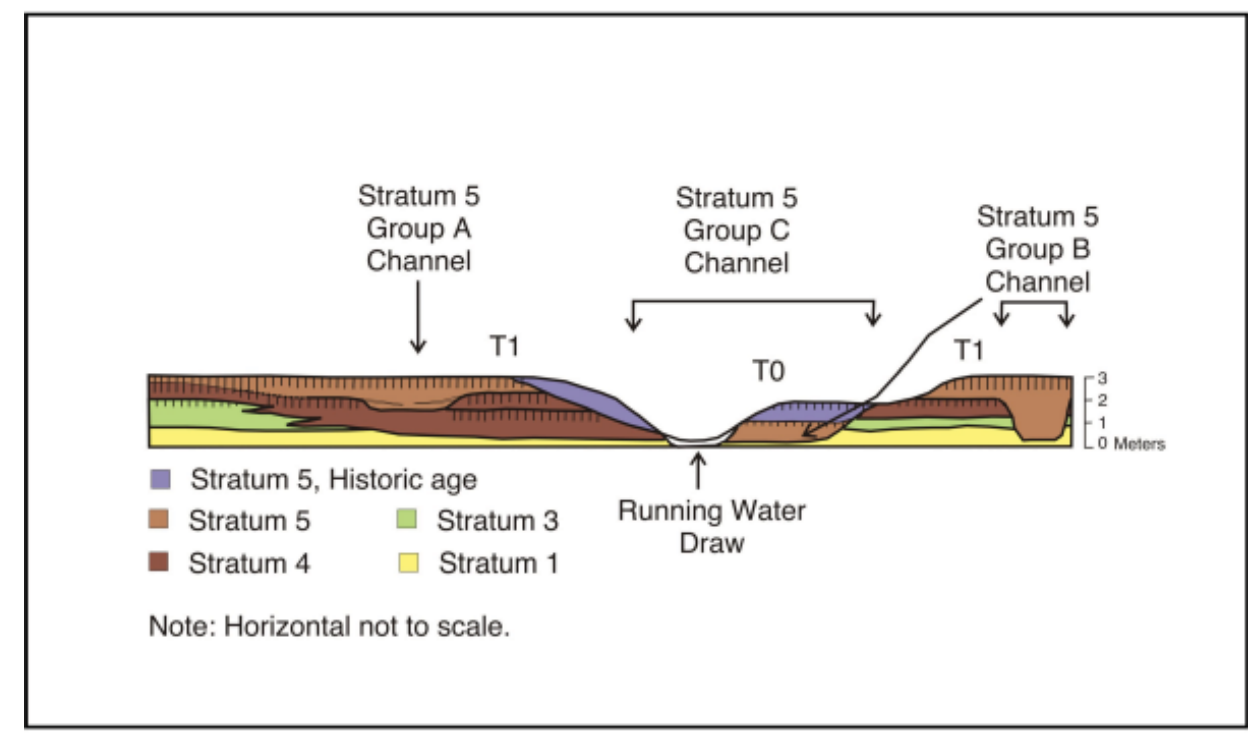

Figure 6-8. Cartoon sketch illustrating the stratigraphy observed in Running Water Draw during this project. 
Group C. Group A comprises a series of channels that are shallowly (ca. $1 \mathrm{~m}$ ) incised into the $\mathrm{T} 1$ surface that completely filled with sediment and retain no surface expression today. The Group B channel is deeply incised (ca. $3 \mathrm{~m}$ ) into the first terrace, and like the Group A channels, is completely filled with sediment and exhibits no surficial evidence that indicates where the channel lies buried. Holliday observed this channel assemblage at the Quincy Street excavation. The last channel, Group C, is associated with the modern floodplain. The floor of this channel is cut about two meters below the first terrace.

\section{Trench 4}

This trench was placed into the floodplain of the last natural channel of Running Water Draw at the point where it intersects the rectified modern channel, about one block west of where the draw crosses Broadway Street. It was located on the east side (or left bank) of the natural channel and was excavated to a depth of $2.4 \mathrm{~m}$, where the caprock caliche was encountered. Figure 6-9 is an annotated photograph of the GT4 exposure, showing the major geologic features, and the results of radiocarbon dates obtained during this project. With the exception of the lowest 10-15 cm, the deposits revealed were thought to be modern alluvium. The basal bed, a medium to coarse cross-bedded sand resting upon the Ogallala Formation, was consistent with Stratum 1. Resting unconformably upon Stratum 1 is about one meter of stratified sand, loamy sand and slightly gravelly sand that was deposited in a channel to near channel overbank setting and capped with a weakly developed soil. A bulk sample of a mud drape near the base of this deposit $(200-205 \mathrm{~cm})$ yielded an age of 2,920 \pm 40 years BP (Beta-224048) and another sample collected from the top of the buried soil at 125-128

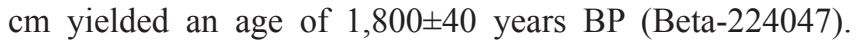
These dates indicate that this deposit is part of Stratum 5 and the lower part of the Group B channel complex. A meter of slightly stratified sand to loamy sand was observed resting on top of the buried soil and a piece of bone collected from the middle of this deposit yielded a radiocarbon age of $350 \pm 40$ years BP (Beta-224046). This deposit is clearly part of the sediments associated with the modern channel, Group C. A thin $(20 \mathrm{~cm})$ deposit of anthrogenic fill buried a weak soil formed at the top of the Group C channel sediment.

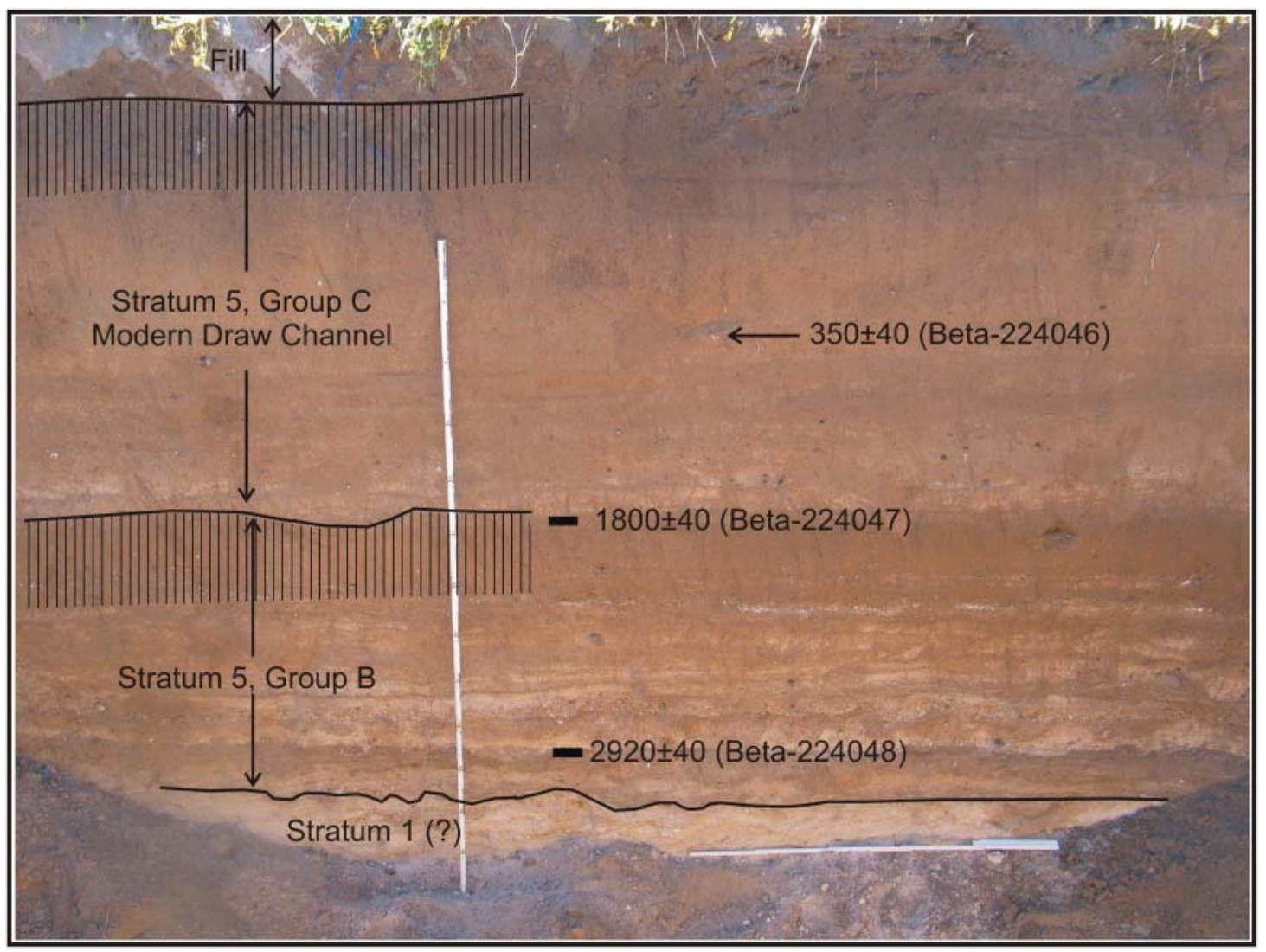

Figure 6-9. Photograph of the north wall of Gradall Trench 4, annotated to show the location of major stratigraphic features (e.g. buried soils), Holliday's stratigraphic units, and the results of radiocarbon dates obtained for bone (the top date) and bulk sediment (the lower two radiocarbon dates). 


\section{Trench 11}

Like Trench 4, this trench was excavated at the point where the natural channel of Running Water Draw joins the rectified, artificial channel about one block west of Broadway Street. It was situated on the right bank of the last natural channel and was purposefully excavated along the sloping scarp that separated the modern floodplain of the natural channel of Running Water Draw from the first terrace. For this reason, we anticipated lateral complexity in the deposits.

Four distinct deposits were exposed by GT11 (Figure 6-10). At the west end, the trench was excavated down to the top of the Ogallala Formation caprock caliche, but at the east end, the trench penetrated into the caprock about $30 \mathrm{~cm}$. A thin sand rested upon the Ogallala. It is possible that this is Stratum 1 , but there was not enough of the deposit to be certain. At the east end of the trench was a series of interbedded weakly developed soils and alluvial sediments which appear to be Stratum 4 (zones 8 to 12 ), but it is also possible that this is a lower component of Stratum 5. A prominent, yet relatively shallow, cut and fill alluvial channel was present at the west end of the trench. This Group A channel was cut into the preexisting deposits by at least one meter and initially filled with a series of interbedded sands and muds. Numerous bison bones were uncovered within the basal beds of this channel and two of these were radiocarbon dated. The resulting dates are in reversed order, overlap at one standard deviation, and indicate that this channel was formed around 3500 years ago. The age of the bison remains are consistent with Holliday's Stratum 5. A short column of diatom samples was collected from the basal channel deposits in this trench. Winsborough (2007:3) reports that the samples are "characteristic of standing or slow-flowing, somewhat alkaline water with a vegetated bottom and moderate to elevated salinity" with a $\mathrm{pH}$ in the 7 to 8.5 range, shallow to very shallow, and normally clear except during floods when it became muddy.

The last deposit exposed in Trench 11 is a wedge of sediments associated with the modern, un-rectified channel of Running Water Draw (Group C). This suite of sediment consists of alternating coarse and fine, often organic-rich sediments, that pinch out upslope to the west. A consistent line of Historic age metal and glass artifacts were observed near the base of these deposits. One of the city employees suggested this could be spoil dredged from the rectified channel, but the geometry of the sediments is more consistent with natural floodplain sedimentation than dredge spoil.

\section{Trench 10}

Trench 10 was placed upon the first terrace surface west of Joliet Street and revealed a shallow incised channel associated with Stratum 5, very similar to the channel at the west end of
Trench 11 (Figure 6-11). The base of this Group A channel was cut approximately one meter into the underlying Stratum 4 deposits and exhibited alternating thin beds of sand and clay, several of which contained numerous aquatic mollusks (snails and bivalves). Two bison skulls were found resting upon a muddy deposit with a very undulatory, trampled surface (zone 14), and a piece of one of these bones yielded a radiocarbon age of $2740 \pm 40$ years BP (Beta-224049). The deposits appeared to represent the channel of Running Water Draw. A short column of diatom samples yielded results similar to the column from Trench 10 (see Winsborough 2007; this volume) and indicate that this channel contained a flowing stream. The presence of bison remains in both of these channels probably indicates that the stream was a reliable water source at this time. The trench also captured the transition from channel to floodplain facies, with the latter being more massive and lacking the highly bedded deposits of the channel, with the exception of a basal sand bed that rested unconformably upon the erosional interface with Stratum 4.

\section{Discussion}

Conversations with Vance Holliday indicate that he would consider all of these sediments as part of Stratum 5 (Vance Holliday, 2008, personal communication). As noted previously, between Holliday's observations at Quincy Street (where he observed a Stratum 5 channel incised three meters deep below the first terrace surface and the observations made during this project, there appear to have been at least three phases of channel entrenchment associated with Stratum 5. The first of these, Group A, is represented by the shallowly entrenched channels documented in Trenches 10 and 11 and appears to represent the initial phase of stream activity in the late Holocene, staring sometime around 3,500 years BP. The base of this channel was cut about one meter into the draw valley floor, and lithologic and diatom evidence indicate that this channel contained shallow flowing water. It is difficult to determine with precision how long this channel persisted, but we estimate that Running Water Draw abandoned this course sometime between 1800 and 2740 years BP.

Somewhere in this period, Running Water Draw incised a new channel three meters below the first terrace surface (Group B), and the fact that we find discretely preserved remnants of the earlier channel suggests that this probably occurred in association with an avulsion event during one or more large magnitude floods. Two exposures have documented this second channel: Holliday's trench at Quincy Street, and Trench 4 of this study. The period of the channel incision is somewhat difficult to determine as our existing radiocarbon dates conflict. The bulk sediment date on an alluvial mud near the base of the Group B channel deposits in Trench 4 of 2920 years BP appears to be at odds with the bison bone 


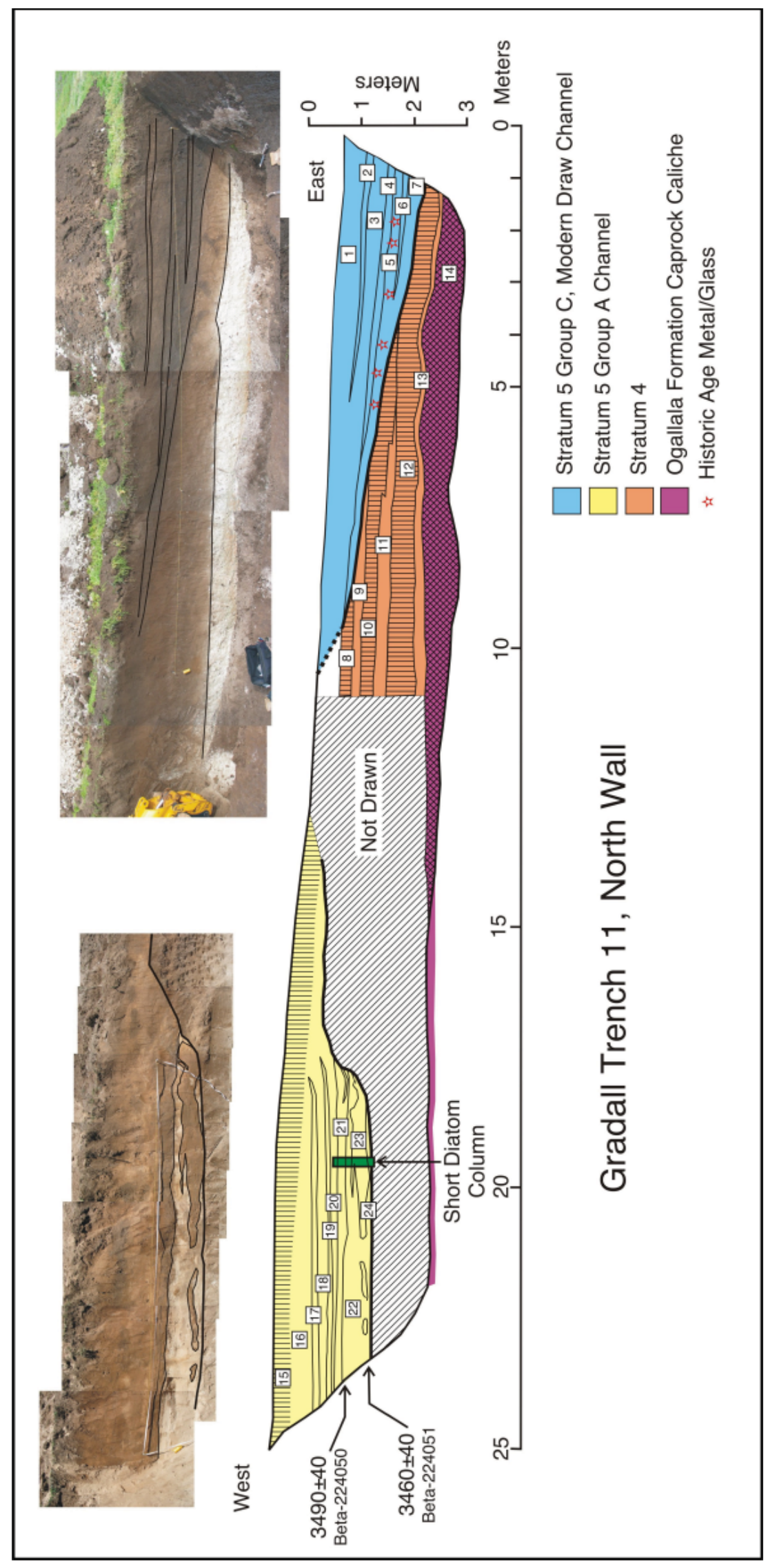

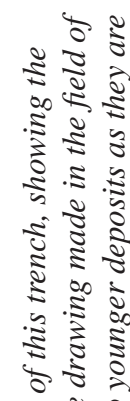

๘ :

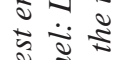

范

ธิ

范

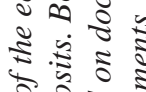

के के है

:

范

$\sum^{1} \cos ^{2} 8$

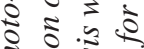

Q

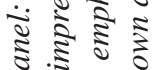

$\therefore, \frac{a}{2} \frac{1}{4}$

它.

$\dot{1} 0 \equiv$

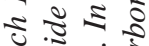

ญे

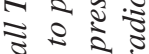

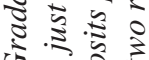

पे ईू

放

ธิ के

ఏँ :

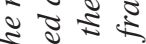

ธิ 己)

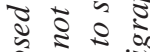

श च च

के के 8

जิ :

की

वे ㄱำ

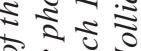

ริ

हें च

के $\frac{0}{2} \frac{\pi}{8}$

范

은

$b \stackrel{5}{\approx}$

ป छ

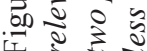




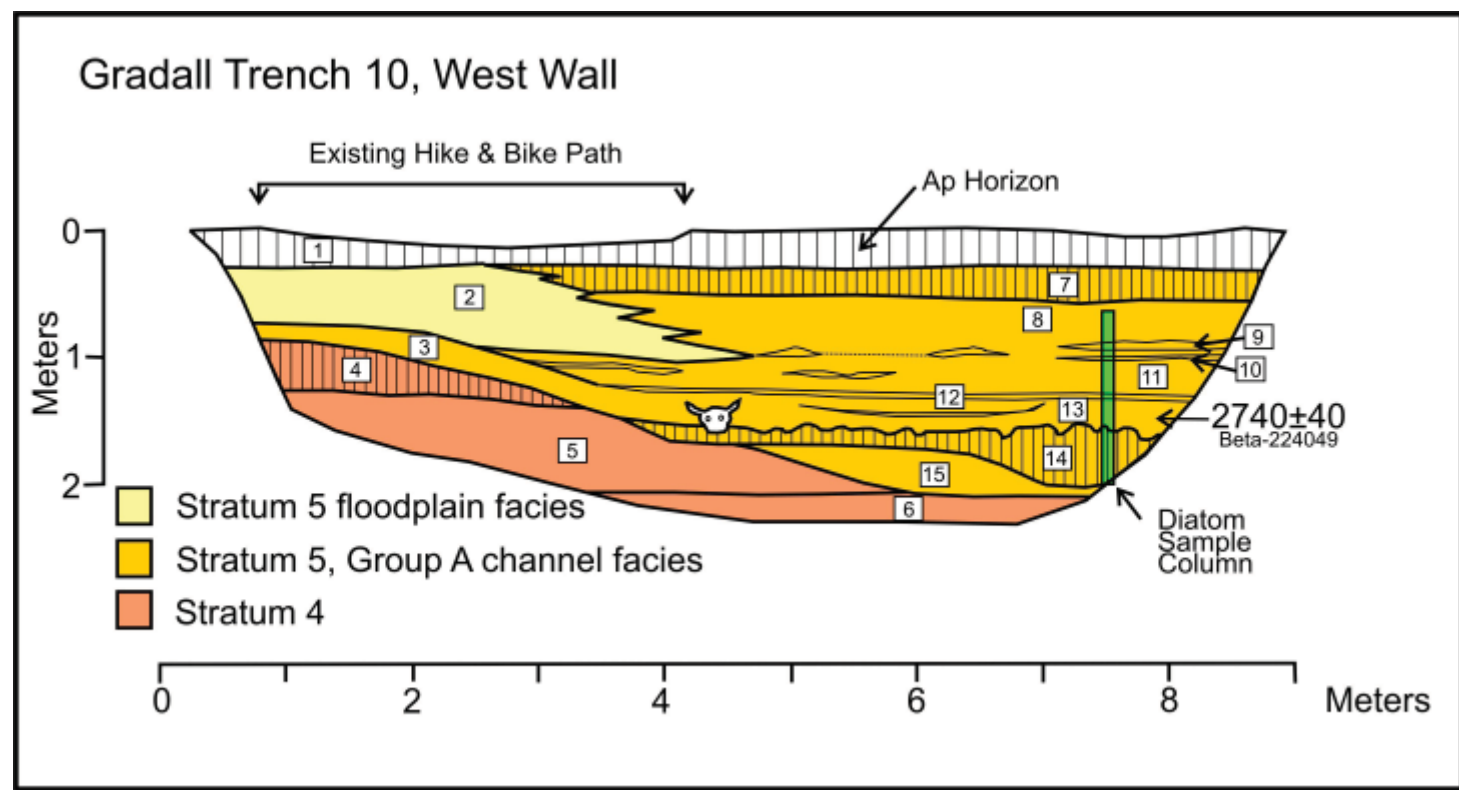

Figure 6-11. Line drawing of the stratigraphy revealed by the north wall of Gradall Trench 10. The radiocarbon date is from bison bone found on the zone 13/14 interface.

dated from Group A channel in Trench 10 that yielded an age of 2720 years BP. At this point, there are no grounds for rejecting either date, but bulk sediment dates often incur an age error from the incorporation of old organic carbon, so we suspect that the 2920 BP date is too old, which is why we bracket the Group B entrenchment event between 1,800 years BP and after 2,740 years BP. These two prehistoric channels fit well with Holliday's general description of Stratum 5 within Running Water Draw, as he notes that there are, in many places, two distinct phases of Stratum 5 floodplain sedimentation separated by a weak soil.

A third phase of channel entrenchment, Group C, is inferred from the incised morphology of the last natural channel of Running Water Draw, the floodplain which lies about one meter below the first terrace, and for which there appears to be at least one meter of Historic age sediments. In Trench 11, we observed approximately one meter of sediment beneath the modern floodplain that contained glass and metal artifacts, and in Trench 4 a piece of bone collected from the middle of the one meter thick modern draw sediments yielded a radiocarbon age of 350 years BP. The phase of channel entrenchment that formed the modern floodplain and channel must have occurred after 1800 years BP and before 350 years BP. There is no lithologic evidence we observed that flooding by Running Water Draw in the Historic Period inundated the first terrace, but the subsequent channelization of the draw would seem to suggest that this did occur.
The final act in the late Holocene history of Running Water Draw was the forced abandonment of the Historic channel sometime in the early part of the last century, when flow within the draw was diverted well to the south of downtown Plainview into an artificially cut drainage canal that now passes quite close to 41HA1. This presumed flood control project probably occurred sometime in the late 1930s or early 1940s.

\section{Results of Investigations near 41HA1}

Two trenches (GT20 and GT21) were excavated in direct proximity to $41 \mathrm{HA} 1$, where the hike and bike trail crosses the drainage ditch/channelized section of Running Water Draw just east of Joliet Street. The trenches were placed for maximum exposure where the trail construction would potentially impact the Paleoindian age deposits, if any were present, specifically where the right-of-way path crossed the toe of the sloping margin of the drainage ditch (see Figure 6-12). The stratigraphy revealed by these two trenches was similar, but GT20 was closer to the original site and appeared to be less disturbed, especially near Stratum 1, the presumed location of the Plainview bone bed deposits. The lower part of the exposures appeared to be most affected by post-depositional disturbance, specifically bioturbation by burrowing animals, probably penetrating from the exposed wall of the drainage ditch. This disturbance was prominent given that these deposits were laminated and/or cross bedded when undisturbed, and because burrowing had interrupted at least one depositional stratum. 


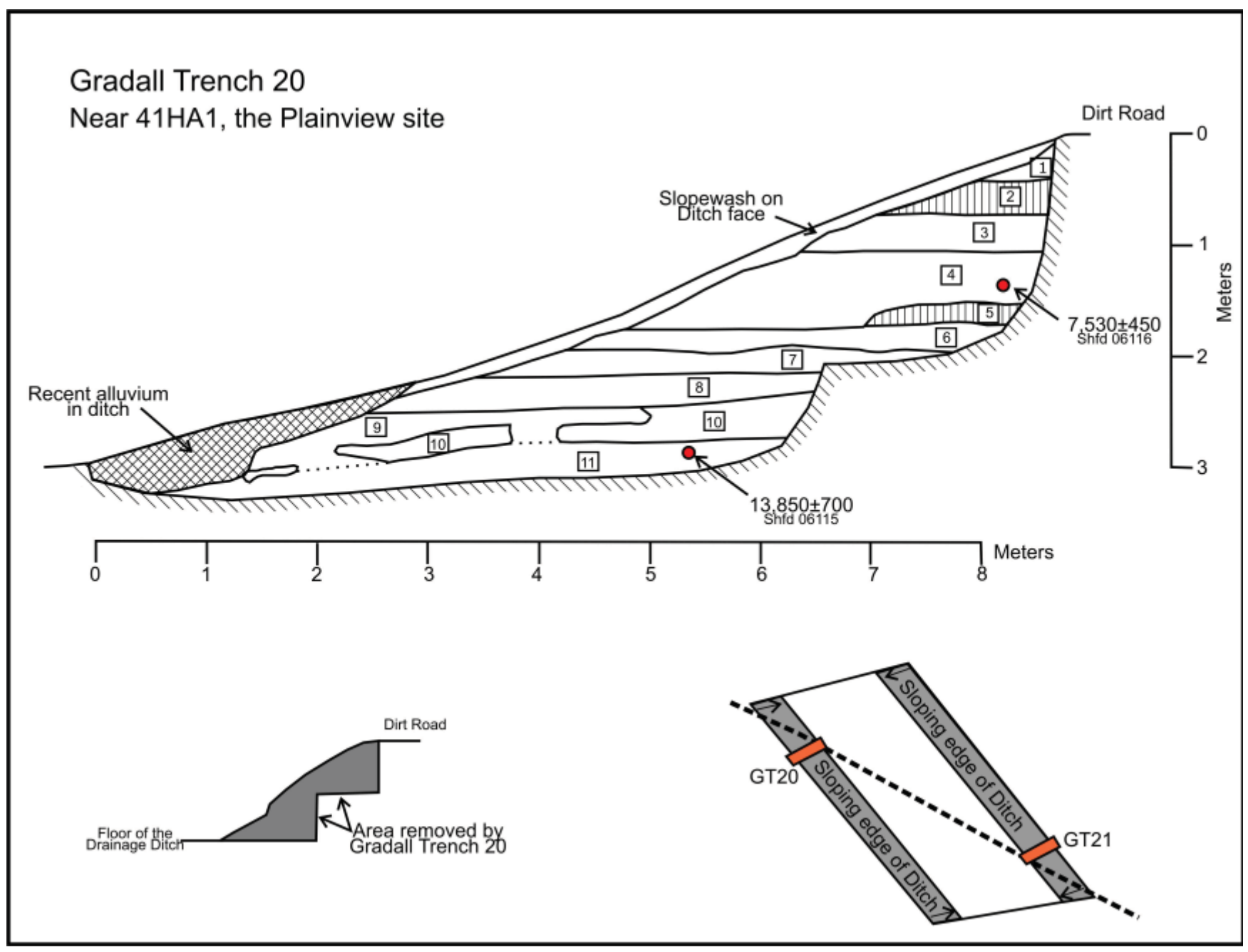

Figure 6-12. Field sketch of the lateral distribution of the deposits exposed within Gradall Trench 20.

Given the dearth of detail on the sedimentary deposits from excavations of the site, and the fact that GT20 was to be the closest excavation to the site since Guffee (1979), we decided to collect samples that would contribute more to the understanding of the site and its history from our closest exposure, specifically GT 20. A column of samples was collected from this trench for bulk soil analyses, diatom analysis, and two samples were collected for single grain optically stimulated luminescence (OSL) dating. Field description of the GT 20 exposure is provided on Table 6-3.

\section{Results}

The results of this work are presented in Table 6-4 and plotted on Figure 6-13. Three of the master draw strata identified by Holliday (1997) were observed in GT20: Stratum 1, Stratum 3 (the marl), and Stratum 4s.

\section{Stratum 1}

The basal deposit of GT20 was clearly Holliday's Stratum 1, which was the deposit from which the Plainview Site was excavated. This deposit, comprising mostly laminated and cross-bedded, moderate to moderately well sorted fine sand with a trace of gravel, rested unconformably upon the Ogallala Caprock Caliche. A slightly coarser pebble lag was present at the base of this deposit. Within the trench, this deposit had been disturbed by burrowing animals, and this disturbance was more prevalent closer to the draw channel and diminished away from the sloping edge of the ditch. The deposit contained almost no measurable calcium carbonate $(<2 \%)$ and had a very low magnetic susceptibility and organic carbon content. Stable carbon isotopic composition of the basal sample yielded a value of -28.78 per mil PDB, which indicates predominantly $\mathrm{C} 3$ photosynthetic pathway plants as a source for the organic carbon in this deposit and is consistent for wetland environments in general and the 
Table 6-3. Gradall Trench 20 Field Description

\begin{tabular}{|c|c|c|c|c|}
\hline Zone & Horizon & Depth (cm) & Description & $\begin{array}{c}\text { Holliday } 1997 \\
\text { Correlative }\end{array}$ \\
\hline 1 & $\mathrm{C}$ & $0-40$ & $\begin{array}{l}\text { Introduced fill associated with the landfill and construction and } \\
\text { maintenance of the dirt road that borders the land fill/draw channel, } \\
\text { not described in detail. }\end{array}$ & None \\
\hline 2 & A & $40-72$ & $\begin{array}{l}\text { Very dark gray (10YR } 3 / 1 \text {, moist) to very dark grayish brown (10YR } \\
3 / 2 \text {, moist) clay loam, friable, moderate medium subangular blocky } \\
\text { structure, gradual smooth boundary, very strongly effervescent. }\end{array}$ & Stratum 4 \\
\hline 3 & Bw1 & $72-103$ & $\begin{array}{l}\text { Dark brown (10YR } 3 / 3 \text {, moist) clay loam to sandy clay loam, friable to } \\
\text { very friable, weak coarse prismatic structure parting to weak medium } \\
\text { subangular blocky structure, clear smooth boundary, very strongly } \\
\text { effervescent, few ( } 1-3 \% \text { ) calcium carbonate filaments, few }(1-5 \%) \\
\text { coarse fragments ( mostly rounded reworked) caliche. }\end{array}$ & Stratum 4 \\
\hline 4 & Bw2 & $103-148$ & $\begin{array}{l}\text { Brown }(7.5 Y R \text { R/4, moist) sandy clay loam, very friable, weak coarse } \\
\text { prismatic structure, clear smooth boundary, strongly to very strongly } \\
\text { effervescent, few (1\%) calcium carbonate filaments, few }(1 \%) \text { coarse } \\
\text { fragments (widely scattered } 0.2-1.5 \mathrm{~cm} \text { diameter rounded reworked } \\
\text { caliche); A single grain OSL sample collected from this zone at a depth } \\
\text { of } 130 \mathrm{~cm} \text { yielded an age of } 7,530 \pm 450 \text { years BP (Shfd } 06116) \text {. }\end{array}$ & Stratum 4 \\
\hline 5 & $2 A b$ & $148-170$ & $\begin{array}{l}\text { Dark grayish brown (10YR } 4 / 2 \text {, moist) loam, very friable, weak coarse } \\
\text { subangular blocky structure, clear smooth boundary, very strongly } \\
\text { effervescent, few krotovina, this zone pinches out toward the draw } \\
\text { within this trench. }\end{array}$ & $\begin{array}{l}\text { Stratum3/ } \\
\text { Stratum } 4\end{array}$ \\
\hline 6 & 2Bk & $170-188$ & $\begin{array}{l}\text { Grayish brown }(2.5 \mathrm{Y} 5 / 2) \text { clay loam to loam, very friable, weak } \\
\text { coarse prismatic structure, abrupt smooth boundary, very strongly } \\
\text { effervescent, common medium }(0.5 \text { to } 1 \mathrm{~cm}) \text { hard irregular shaped } \\
\text { nodules and a few soft concentrations of calcium carbonate, marl. }\end{array}$ & Stratum 3 \\
\hline 7 & 2Bkg1 & $188-203$ & $\begin{array}{l}\text { Grayish brown }(2.5 Y 5 / 2) \text { loam to sandy clay loam, friable, weak } \\
\text { coarse subangular blocky structure, clear smooth boundary, very } \\
\text { strongly effervescent, common thin discontinuous coats of calcium } \\
\text { carbonate on ped faces. }\end{array}$ & Stratum 3 \\
\hline 8 & 2Bkg2 & $203-241$ & $\begin{array}{l}\text { Light brownish gray }(2.5 \mathrm{Y} 6 / 2) \text { clay to clay loam, firm, strong thin to } \\
\text { medium platy structure, abrupt smooth boundary, common to many } \\
\text { thin discontinuous coats of calcium carbonate on ped faces, abundant } \\
\text { diffuse calcium carbonate, marl. }\end{array}$ & Stratum 3 \\
\hline 9 & $2 \mathrm{C} 1$ & $241-262$ & $\begin{array}{l}\text { Light brownish gray (10YR } 6 / 2 \text { ) loam to sandy loam, firm, strong } \\
\text { medium angular blocky structure, clear smooth boundary, very strongly } \\
\text { effervescent, few thin discontinuous coats of calcium carbonate on } \\
\text { ped faces. }\end{array}$ & Stratum 3 \\
\hline 10 & $2 \mathrm{C} 2$ & $262-300$ & $\begin{array}{l}\text { Grayish brown (2.5Y } 5 / 2 \text {, moist) sandy loam to sand, very firm, weak } \\
\text { extremely coarse angular blocky structure, abrupt wavy boundary, } \\
\text { strongly effervescent, few fine faint diffuse olive ( } 5 \text { Y } 5 / 6) \text { mottles, } \\
\text { common small aquatic snails and bivalves (clams) between } 280-290 \\
\mathrm{~cm} \text {. }\end{array}$ & Stratum 3 \\
\hline 11 & $3 C$ & $300-330$ & $\begin{array}{l}\text { Light gray (10YR } 7 / 2 \text {, moist) sand, loose, single grained, abrupt } \\
\text { irregular boundary, weakly effervescent, few aquatic snails, laminated } \\
\text { and cross-bedded in places, very bioturbated in some places, } \\
\text { especially in proximity to the ditch surface, base of the zone rests } \\
\text { on the Ogallala Caprock Caliche and contains a few }(1 \%) \text { coarse } \\
\text { fragments; A single grain OSL sample collected from this zone at a } \\
\text { depth of } 305 \mathrm{~cm} \text { and yielded an age of } 13,850 \pm 700 y e a r s \text { BP (Shfd } \\
06115) \text {. }\end{array}$ & Stratum 1 \\
\hline
\end{tabular}




\begin{tabular}{|c|c|}
\hline $\begin{array}{l}\frac{\infty}{0} \\
\frac{0}{0} \\
\frac{1}{2} \\
\underline{\Sigma}\end{array}$ & 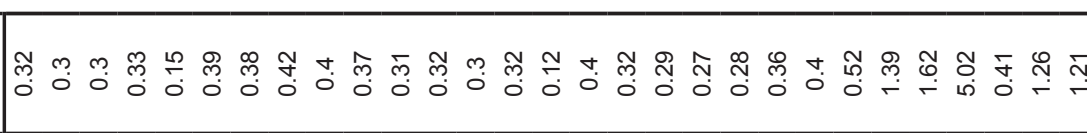 \\
\hline 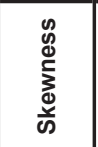 & 在 \\
\hline 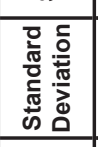 & 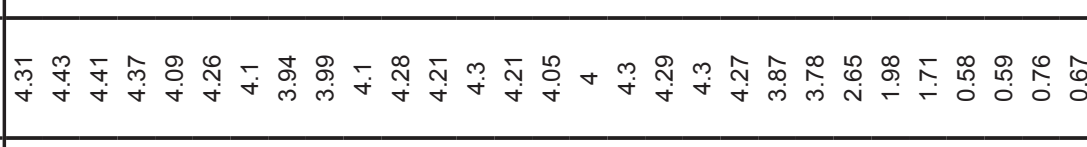 \\
\hline$\stackrel{\frac{c}{\Phi}}{\Sigma} \overline{\bar{c}}$ & 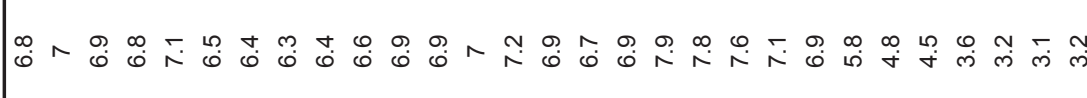 \\
\hline $\begin{array}{l}\stackrel{\circ}{0} \\
\frac{\pi}{0}\end{array}$ & 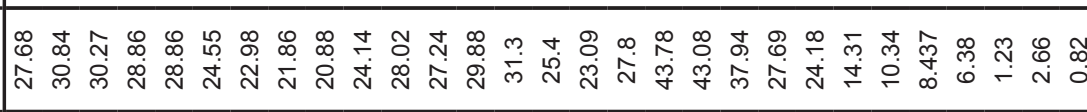 \\
\hline $\begin{array}{l}\stackrel{\circ}{\omega} \\
\stackrel{+}{\omega}\end{array}$ & 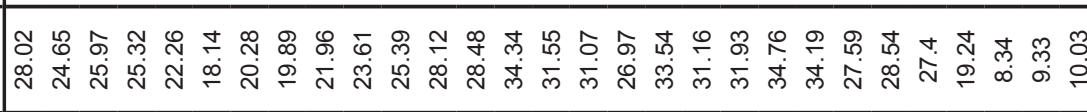 \\
\hline 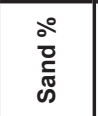 & 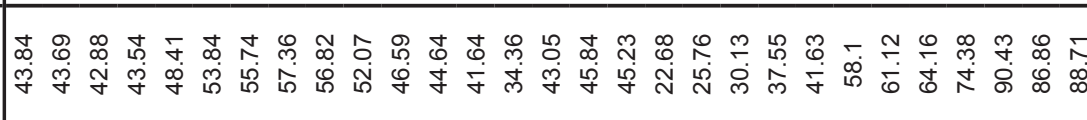 \\
\hline $\begin{array}{l}\stackrel{\circ}{\Phi} \\
\stackrel{0}{0} \\
\stackrel{0}{0} \\
\end{array}$ & 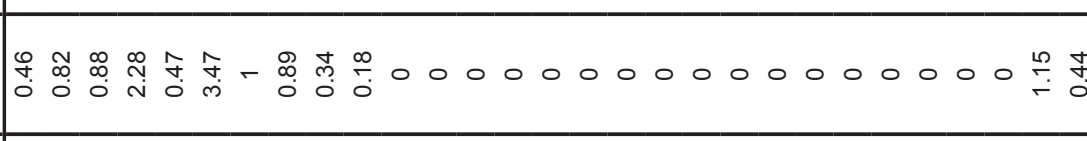 \\
\hline 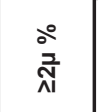 & 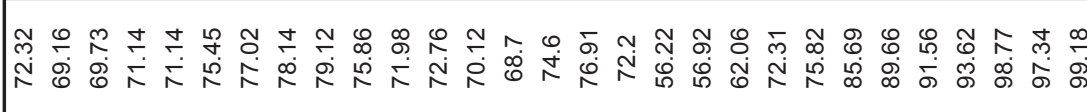 \\
\hline 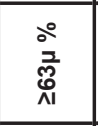 & 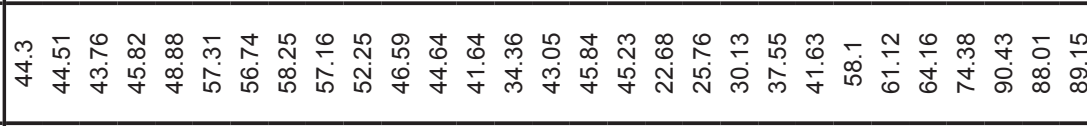 \\
\hline 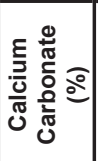 & 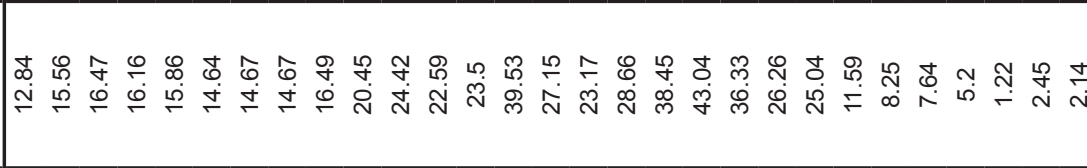 \\
\hline 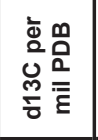 & 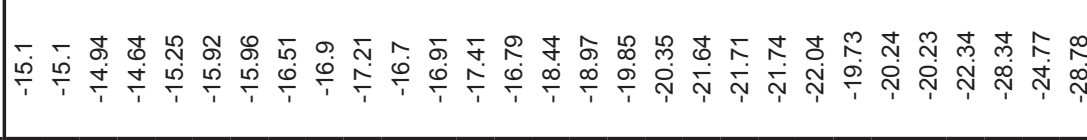 \\
\hline 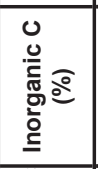 & 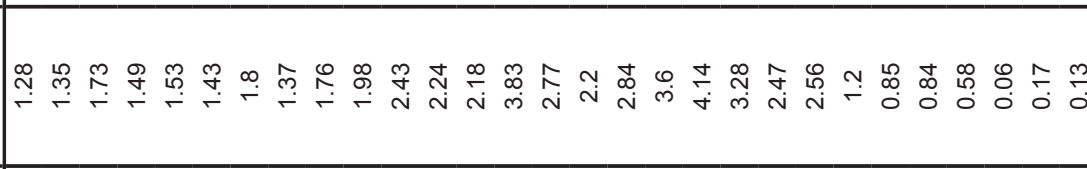 \\
\hline 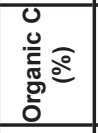 & 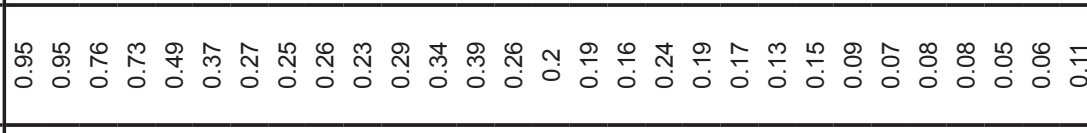 \\
\hline 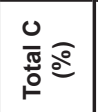 & 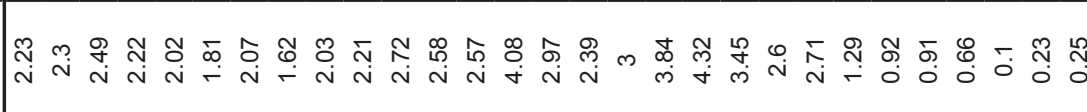 \\
\hline$x^{ \pm}$ & 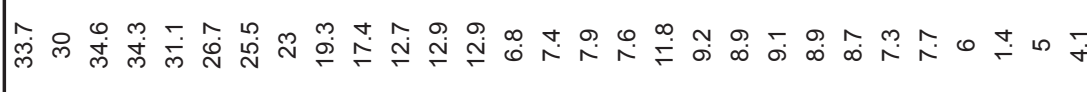 \\
\hline 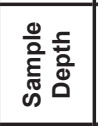 & 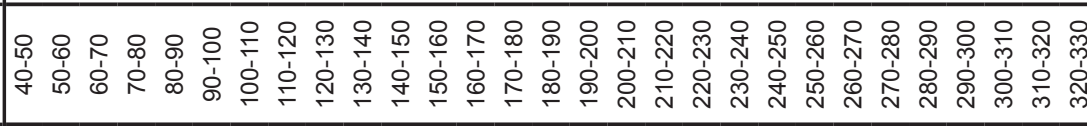 \\
\hline 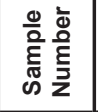 & 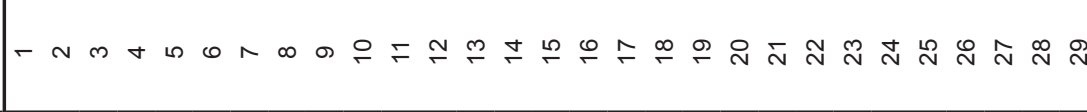 \\
\hline
\end{tabular}




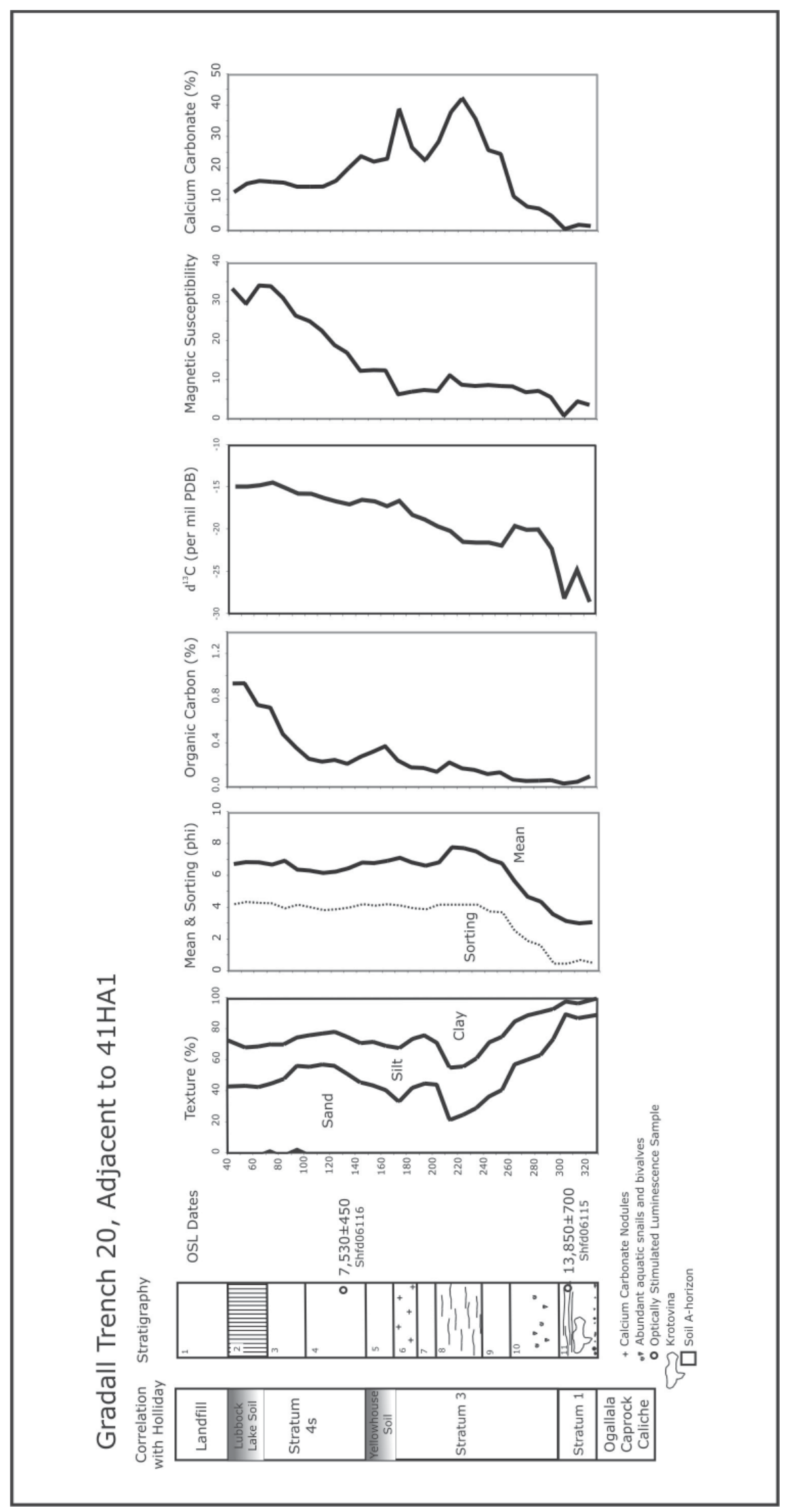

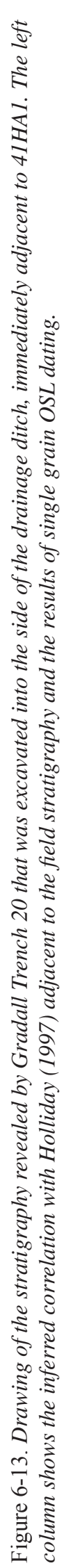


late Pleistocene-early Holocene sediments of Llano Estacado draws in particular (Holliday 1997: 55-57). Analysis of molluscan remains by Neck (1997:65) from Pit 3, downstream of this locality suggest that the draw at this time was occupied by "a permanent stream with resident fish population and quiet water margins; lateral zone occupied by hydric marsh; abundant cover objects. Clay lens within stratum 1 associated with a cold water spring and pool with variable water levels, terrestrial margin dry and harsh".

An OSL sample was collected from a depth of $305 \mathrm{~cm}$ within this deposit to date deposition of Stratum 1. This sample was dated using the single grain OSL method and the OSL age was determined for 66 grains, of which 5 were zero dose grains, which had been reset recently. Bateman's (2007) report clearly shows that all of the zero dose grains were recorded in sequence, and probably on a single disc, which gives cause to question whether this may be the result of an instrumental or lab error of some form. The probability of all of the zero dose grains in this sample being recorded in sequence, when they comprise only $5 \%$ of the sample, is remote. The sediment where the sample was collected was laminated and appeared undisturbed, but it is impossible to be certain that none of this sample behind the trench wall was unaffected by the bioturbation that was clearly present within this deposit. Nevertheless, this issue is largely academic as these grains were excluded from the population that was used to calculate the sample age. The age calculation employed a central tendency model and used only grain ages within two standard deviations of the mean. This model yielded an age of 13,850 700 years BP (before 2007; Sheffield 06115). This age is approximately equivalent to a calibrated radiocarbon age of 11,635 \pm 540 years BP. To our knowledge, this is the only OSL date for Stratum 1 available on the Southern High Plains at this time.

\section{Stratum 3}

The carbonate-rich marl or sandy marl, Stratum 3, is reported by Holliday (1995:38) to be the best-dated depositional units within the draws on the Southern High Plains. It was deposited in a broad period between 10,000 and 7500 years BP and represents deposition by small perennial streams.

In GT 20, Stratum 3 was about $1.5 \mathrm{~m}$ thick, which is considerably thicker than it was recorded by Holliday at either Pit 2 (where it was about $40 \mathrm{~cm}$ thick) or in Pit 3 (where Holliday 1990 shows it to be a quite thin band compared to either Stratum 1 or Stratum 4). Records of the sedimentary sequence at the two excavations make it difficult to determine if this deposit was present at the original site, but Sellards and Guffee's description of the deposit on top of Stratum 1 as a "massive compact sandy clay" sounds similar to Stratum 3 in GT 20. Furthermore, the section we documented exhibited two distinct fining upward sedimentary cycles, which were capped by a faint soil (the Yellowhouse Soil). The finer textured zones were also clearly very calcium carbonate-rich and there exists a very strong positive correlation between calcium carbonate content and clay content for this deposit. Some of the carbonate near the top of Stratum 3 appeared to have been re-organized by pedogenic processes into nodular forms (cf. zone 6).

We collected samples for diatom analysis from Stratum 1 and Stratum $3(175-315 \mathrm{~cm})$ but Winsborough (2007; this volume) notes that almost no diatoms were present in these samples, and those that were present were heavily diluted with sediment and often broken. It is paradoxical that the diatom assemblage from this deposit was so heavily degraded, but the molluscan assemblage preserved clear evidence of aquatic habitats and well-preserved specimens. In retrospect, it is unfortunate that we failed to submit these samples for analysis. Neck's (1997:64-65) reconstruction of the Stratum 3 depositional environment from molluscan samples collected by Holliday in Pit 3 records a change from a

small perennial stream with associated pools of quiet water, lateral marsh habitat, mid-elevation riparian vegetation band with woody plants including shrubs and some small trees; welldrained habitat upslope [at the base of the unit, to a] stream or pool that contained less water and a terrestrial habitat that contained no significant amounts of woody vegetation [Neck 1997:64$65]$.

A pronounced decline in species diversity was also noted by Neck within Stratum 3.

The stable carbon isotopic record for Stratum 3 is fragmentary, but values for this deposit become increasingly heavy, starting around -22 per mil in the upper half of zone 9, and increasing to around -17 per mil in the Yellowhouse soil. This suggests that the vegetation on the valley floor throughout the period shifts from a $\mathrm{C} 3$ dominated assemblage to one that is increasingly dominated by $\mathrm{C} 4$ plants and is consistent with Neck's paleoenvironmental interpretation based upon the molluscan assemblage.

\section{Stratum 4s}

The last major depositional unit present in GT20 was Stratum 4s. This deposit comprised approximately one meter of clay 
loam to sandy clay loam and within which a prominent soil had formed (the Lubbock Lake Soil). The relatively fine texture along with traces of gravel suggest that this is an alluvial deposit, and Holliday notes that across the Llano Estacado the deposition of Stratum 4 occurred between approximately 7,500 and 4,500 years B.P.

The Stratum 4 sediments in GT 20 are considerably less calcareous than Stratum 3 and exhibit only very gradual depositional trends. To be specific, the unit appears to coarsen slightly immediately following burial of the Yellowhouse soil, and then becomes slightly finer.

An OSL sample collected from just above the base of Stratum 4 at $130 \mathrm{~cm}$ yielded a single grain age of 7,530 450 years BP (before 2007; Sheffield 06116) and this is roughly equivalent to a calibrated radiocarbon age of $6690 \pm 400$ years BP. The 56 grains that were dated from this sample exhibited a broad temporal distribution that suggests some of the grains were not completely reset during transportation. Bateman (2007) speculates that the old age of some of the grains forming the tail of the single grain distribution for this sample could be the artifact of mixing with underlying, older deposits, but the apparent age of these grains (Paleodose (De) values in excess of 30 Grays is too great for what would be present immediately beneath Stratum 4. The OSL sample from Stratum 1 only had a few grains of this apparent age as well, which suggests that this is an artifact of the transportation process. Feathers et al. (2006) and Feathers (2003) recently reported OSL ages from a number of sites across the Southern High Plains, including two from Stratum 4 at the Mustang Springs Site. There, Feathers et al., (2006:1662) obtained single grain

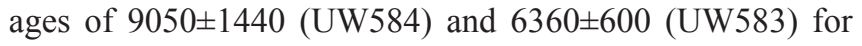
samples that had independently determined radiocarbon ages of 9000 and 7700 years BP, respectively. Although we have no independent age evidence, the OSL date obtained here for Stratum 4 seems to conform with expectations derived from the corpus of Holliday's (1995) work on the draws in general, and extant OSL dates for Stratum 4 (Table 6-4).

\section{Comparison with Holliday's (1985) Pit 2 Profile}

The nearest point of comparison for GT 20 is immediately across the draw channel to the north, where Holliday (1985) sampled a section from near the northwest corner of Pit 2 . We were initially concerned that these two profiles, given their apparent proximity were the same, but upon completion of the analysis, it is clear that there are significant lateral changes in the draw stratigraphy between these two sections. Holliday (1985) reports observing three strata in the Pit 2 section: specifically Strata 5, 4, and 1 (Note: it is important to consult Table 7a of Holliday (1995:34) when linking his 1985 stratigraphy to the most recent and comprehensive statement on the Draw deposits). The majority of this section is comprised of Stratum $5(\sim 1 \mathrm{~m})$ and Stratum $4(\sim 0.8 \mathrm{~m})$, which together amount to about $85 \%$ of the pre-landfill deposits exposed. The base of the section comprised approximately $40 \mathrm{~cm}$ of Stratum 1. From this Holliday correlated Sellards "dark sandy soil" with Stratum 5, the massive compact sandy clay as Stratum 4, and the basal sand and gravel with Stratum 1.

The closer proximity of the GT 20 section to the actual site suggests a different correlation (see Figure 6-14). Specifically, the "dark sandy soil" reported by Guffee (1979) and Sellards et al. (1947) was probably Stratum 4, and the "massive compact sandy clay" was probably Stratum 3. Stratum 5, which Holliday records as the upper part of the profile in the Pit 2 section, must have lapped onto Stratum 4 and the Lubbock Lake Soil somewhere in the vicinity of the modern channelized draw (the "drainage ditch") and thickened rapidly to the north, similar to the section Holliday has drawn from Pit 3 (Holliday 1990:94, Figure 1).

\section{Relevance for the Context of the Plainview Site Bone Bed}

Although Holliday (1997) has concluded upon examination of the blocks of bone and sediment curated by Sellards that the Plainview Site bone bed was within a deposit similar to the "loamy mud filling a bedrock channel" situated on a bedrock bench at the valley margin end of Pit 3 (Stratum $1 \mathrm{~m}$ on Holliday 1995, Figure 26b) and that yielded radiocarbon dates of 11,970 and 10,940 years BP, the color and general description also fit the Stratum 3 deposits we observed resting conformably upon Stratum 1 in GT 20. Conversations with Vance Holliday revealed that he collected samples of this deposit from one of the plaster jacketed blocks opened by Roberta Speer, and subsequently determined particle size and the calcium carbonate content of this bed. Holliday revealed that the bed contained $65 \%$ sand, $17 \%$ silt, and $18 \%$ clay, and $13 \%$ calcium carbonate (Vance Holliday, 2008 , personal communication), which is very similar to the basal part of Stratum 3 in GT 20. The corpus of Holliday's work has demonstrated that the Stratum 1 and Stratum 2 deposits are either noncalcareous or very weakly calcareous. Our work from GT20 documented between two and three percent calcium carbonate for Stratum 1. This information, considered together with comments by Holliday (1997) on the carbonate encrustation of the Plainview bones, strongly point towards the possibility that the Plainview Site bone bed was actually deposited during the initial phases of Stratum 3 sedimentation, which Holliday (1995) notes occurs as early as 10,000 years BP in some settings. The only potential problem with this scenario is that Guffee (1979) noted that the bones he recovered were fully within Stratum 1. 


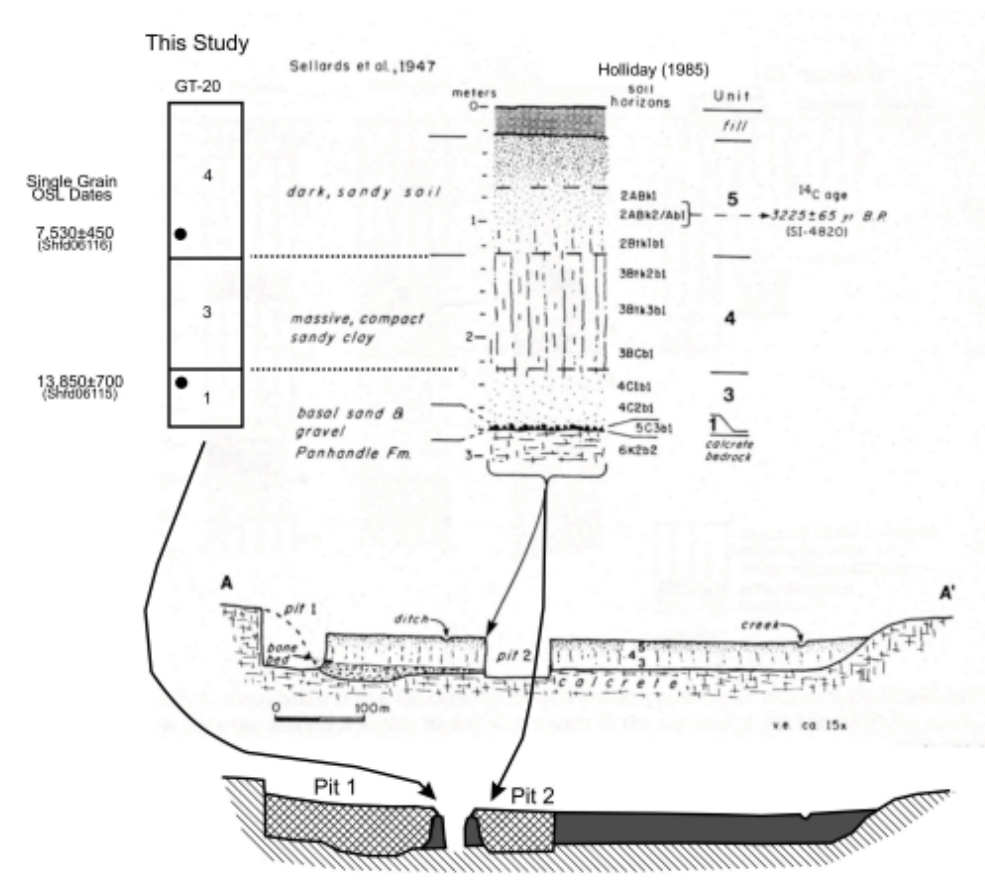

Former borrow pits now filled with rubbish

Areas where in situ Late Quaternary deposits remain

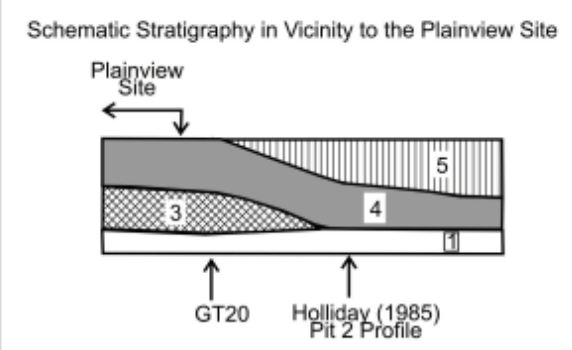

Figure 6-14. A revised version of Holliday (1985, Figure 7; see Figure 3-1) showing: Top Panel the most likely correlation of the draw deposits observed in Gradall Trench 20, with the described deposits of Sellards et al. (1947) and Holliday's (1985) Pit 2 profile; Middle Panel - Holliday's original cross-section A-A' (which is an update of Sellards et al. (1947, Figure 3) and an update showing the existing conditins in proximity to the Plainview Site. Pit 1, which is shown on Holliday's original figures with the boundary it had in 1947 when Sellard's first published the site report, was clearly expanded out to the edge of the now channelized draw (shown as a drainage ditch of both Sellard's and Holliday (1985) and subsequently backfilled with rubbish. Pit 2 along Holliday's section line has also been filled with rubbish but its boundaries appear to be similar to those depicted on Holliday's map; Bottom Panel - A schematic representation of the deposits that are/were present in the immediate vicinity of the Plainview Site based upon the results of Gradall Trench 20, Holliday's Pit 2 profile and Sellard's et al. (1947) descriptions. 


\section{Summary}

The results of the geoarcheological work done in conjunction with the Hike and Bike Trail survey have yielded new information on the stratigraphy of Running Water Draw and raised new questions about the contextual location of the Plainview Site bone bed. In particular, this work has provided considerably new detail on Late Holocene sedimentation within Running Water Draw, which until now had yielded enigmatic results and little solid documentation. The field descriptions and radiocarbon dates clearly demonstrate the presence of three late Holocene channel complexes in Running Water Draw in the last 3500 years.

The results of the work near 41HA1 have also yielded new information potentially relevant to the age of Stratum 1 and the stratigraphic position of the Plainview Site bone bed. In particular, the results presented here, viewed in light of unpublished data on the Plainview bone bed provided by Vance Holliday, suggest that the previously published interpretations of the stratigraphic context of the bone bed may be wrong. These results suggest that the bone bed may actually have been within the basal portion of Stratum 3 and place the age of the Plainview occupation closer to 10,000 years BP. 



\section{Chapter 7: Conclusions}

In March and April of 2005, the Center for Archaeological Research conducted a survey of the proposed Plainview hike and bike trail in Hale County, Texas. The work was conducted for the Texas Department of Transportation under, and in accordance with, work authorization \#57501SA005 and Texas Antiquities permit \#3707. The survey occurred between March 31 and April 7, 2005 and involved pedestrian survey, mechanical augering, and Gradall trenching along segments of the trail ROW, which passes near two previously recorded sites, 41HA1, the Plainview Site, and 41HA12. The survey was designed to identify any significant or potentially significant archeological sites and deposits within the proposed trail ROW that would be adversely impacted by trail modifications and construction of new trail segments. Apart from identifying undocumented archeological sites within the project APE, the research goals of the project included a clearer understanding of the geomorphology of Running Water Draw, including the relationship to the Plainview Site and accurate dating of the deposits, and analysis of the Late Holocene water quality of Running Water Draw. Samples collected during survey were processed and the results of the analysis were in part the subject of this report.

The pedestrian archeological survey with mechanical auger tests did not locate any additional sites. Only one Scallorn projectile point was recovered from the surface. No additional artifacts were found. Faunal material including bison skulls were found in several of the Gradall trenches but without any evidence of cultural material. No cultural material was found in any of the trenches or trench backdirt.

The geological work contributed to the body of knowledge of Running Water Draw but also raised new questions about the context of the Plainview bone bed. These results suggest that previously published interpretation of the bone bed stratigraphic context may be wrong and that the position of the bed within the basal portion of Stratum 3 puts the age of the Plainview occupation closer to 10,000 BP.

No new archeological sites were recorded, and it is CAR's assessment that previously existing archeological sites or deposits will not be adversely impacted by the project. CAR recommends that the project proceed as planned. However, monitoring of construction near the Plainview Site (41HA1), a NRHP property and National Historic Landmark, is recommended given the significance of this archeological site and the possibility of additional deposits associated with the site and its Paleoindian components. In addition, monitoring of construction would serve to mitigate the possible impacts grade excavations could have in the sloping margin of the draw channel within the vicinity of 41HA1. 



\section{References Cited}

American Society for Testing Materials (ASTM)

1985 Standard test method for particle size analysis of soils. D-422-63 (1972). 1985 Annual Book of ASTM Standards 04.08:117-127. American Society for Testing Materials, Philadelphia.

Blakely, E.R., and W.M. Koos

1974 Soil Survey of Hale County, Texas. United States Department of Agriculture, Soil Conservation Survey, in cooperation with the Texas Agricultural Experiment Station. College Station.

Bouyoucos, G.J.

1962 Hydrometer method improved for making particle size analyses of soils. Agronomy Journal 54:464-465.

Boyd, D.K.

1992 Historic Native American Rock Art of Garza County, Texas. In Cultural Encountered and Episodic Drought: The Protohistoric Period on the Southern High Plains, edited by E. Johnson, pp:69-90. Quaternary Research Series 3. Lubbock Lake Landmark, Museum of Texas Tech University.

Boyd, D.K., J.T. Abbott, W.A. Bryan, C.M. Garvey, S.A. Tomka, R.C. Fields

1990 Phase II Investigations at Prehistoric Rock Art Sites, Justiceburg Reservoir, Garza and Kent Counties, Texas. 2 vols. Reports of Investigations No.71. Prewitt and Associates, Inc., Austin.

Dalan, R.A. and S.K. Bannerjee

1998 Solving Archaeological Problems Using Techniques of Soil Magnetism. Geoarchaeology: An International Journal 13:3-36.

Dreimani, A.

1962 Quantitative gasometric etermination of calcite and dolomite by using a Chittick apparatus. Journal of Sedimentary Petrography 32(3):520-529.

Evans, G.L.

1951 Prehistoric Wells in Eastern New Mexico. American Antiquity 17:1-9.

Feathers, J.K.

2003 Single-grain OSL dating of sediments from the Southern High Plains, USA. Quaternary Science Reviews 22:10351042.

Feathers, J.K. V.T. Holliday, and D.J. Meltzer

2006 Optically stimulated luminescence dating of Southern High Plains archaeological sites. Journal of Archaeological Science 33:1651-1665.

Frederick, C.D.

1994 Late Quaternary Geology of the Sulphur Draw Reservoir. In Sulphur Springs Draw: Geoarcheological and Archaeological Investigations at Sulphur Draw Reservoir, Martin County, Texas, By J. Michael Quigg, Charles D. Frederick, and Christopher Lintz, pp. 29-82. Mariah Technical Report No. 776, Mariah Associates, Inc., Austin. 
Freeman M., and D.K. Boyd

1990 Phase II Historical Investigations at Justiceburg Reservoir, Garza and Kent Counties, Texas. Reports of Investigations No. 72. Prewitt and Associates, Inc., Austin.

Gale, S.J., and P.G. Hoare 1991 Quaternary Sediments: Petrographic Methods for the Study of Unlithified Rocks. Belhaven Press, London.

Gee, G.W., and J.W. Bauder

1986 Particle Size Analysis. In Methods of Soil Analysis, Part 1. Physical and Mineralogical Methods. Agronomy Monograph No. 9 (2nd Edition), edited by Arnold Klute, pp. 383-412. American Society of Agronomy - Soil Science Society of America, Madison.

Guffee, E.J.

1976 Merrell-Taylor Village Site. Plainview, Texas. Llano Estacado Museum, Wayland Baptist College.

1979 The Plainview Site: Relocation and Archaeological Investigation of a Late Paleoindian Kill Site in Hale County, Texas. Archeological Research Laboratory, Llano Estacado Museum, Plainview.

Gustavson, T.C., and R.J Finley

1985 Late Cenozoic Geomorphic Evolution of the Texas Panhandle and Northeastern New Mexico: Case Studies of Structural Controls on Regional Drainage Development. Report of Investigations No. 148, The Bureau of Economic Geology, The University of Texas at Austin.

Harrison, B. and K. Killen

1978 Lake Theo: A Stratified, Early Man Bison Butchering and Camp Site, Briscoe County, Texas. Special Archeological Report 1. Canyon Texas: Panhandle-Plains Historical Museum.

Haynes, C.V., Jr.

1995 Geochronology of Paleoenvironmental Change, Clovis Type Site, Blackwater Draw, New Mexico. Geochronology 10:317-88

Hester, J.

1972 Blackwater Locality No. 1: A Stratified Early Man Site in Eastern New Mexico. Publication of the Fort Burgwin Research Center, No. 8, Taos.

1975 Paleoarcheology of the Llano Estacado. In Late Pleistocene Environments of the Southern High Plains, ed. F. Wendorf and J.J. Hester, pp. 247-256. Publication of the Fort Burgwin Research Center No. 9. Taos.

Hicks, K.

2002 Singer Store Research Program for the 1996-1998 Field Season. In Late Holocene Investigation at the Lubbock Lake Landmark edited by E. Johnson. Quaternary Research Center Series No. 11, Museum of Texas Tech University, Lubbock.

Hill, M.G., V.T. Holliday, and D.J. Stanford

1995 A Further Evaluation of the San Jon Site, New Mexico. Plains Anthropologist 40:369-90. 
Hofman, J.L.

1989 Prehistoric Culture History: Hunter Gatherers on the Southern Great Plains. In From Clovis to Comanchero: Archeological Overview of the Southern Great Plains, by J.L. Hofman, R.L. Brooks, J.S. Hays, D.H. Owsley, R.L. Janz, M.K. Marks, and M.H. Manhein, pp. 25-60. Research Series No. 35. Arkansas Archeological Survey. Fayetteville.

Hofman, J.L. and R.L.Brooks

1989 Prehistoric Culture History: Woodland Complexes in the Southern Great Plains. In From Clovis to Comanchero: Archeological Overview of the Southern Great Plains, by J.L. Hofman, R.L. Brooks, J.S. Hays, D.H. Owsley, R.L. Janz, M.K. Marks, and M.H. Manhein, pp. 61-70. Research Series No. 35. Arkansas Archeological Survey. Fayetteville.

Holliday, V.T.

1985a New Data on the Stratigraphy and Pedology of the Clovis and Plainview Sites, Southern High Plains. Quaternary Research 23: 388-402.

1985b Holocene Soil-geomorphological Relations in a Semi-arid Environment: The Southern High Plains of Texas. In Soils and Quaternary Landscape Evolution edited by J. Boardman, pp. 325-357. John Wiley and Sons, New York.

1987 Cultural Chronologies. In Lubbock Lake: Late Quaternary Studies on the Southern High Plains, edited by E. Johnson, pp22-25. College Station: Texas A\&M University Press. College Station.

1990 Investigations of the Plainview Site and Middle Running Water Draw. In Guidebook to the Quaternary History of the Llano Estacado, edited by Vance T. Holliday and Eileen Johnson, pp. 93-104. Lubbock Lake Landmark Quaternary Research Center Series No. 2, Museum of Texas Tech University, Lubbock.

1995 Stratigraphy and Paleoenvironments of Late Quaternary Valley Fills on the Southern High Plains. Geological Society of America Memoir 186. Geological Society of America, Boulder.

1997 Paleoindian Geoarchaeology of the Southern High Plains. The University of Texas Press, Austin.

2001 Stratigraphy and geochronology of upper Quaternary eolian sand on the Southern High Plains of Texas and New Mexico, United States. Geological Society of American Bulletin 113:88-108.

Holliday, V.T., E. Johnson, and T.W. Stafford Jr.

1999 AMS radiocarbon dating of the Plainview and Firstview (Paleoindian) Assemblages: The agony and the ecstasy. American Antiquity 64:444-454.

Holliday, V.T, E. Johnson, H. Haas, and R. Struckenrath

1983 Radiocarbon Ages from the Lubbock Lake Site, 1950-1980: Framework for Cultural and Ecological Change on the Southern High Plains. Plains Anthropologist 27 (101):165-82.

1985 Radiocarbon Ages from the Lubbock Lake Site, 1981-1984. Plains Anthropologist 30 (110):277-91.

Honea, K.H.

1980 The Mark's Beach Site, Stratified Paleoindian Site, Lamb County Texas. Bulletin of the Texas Archeological Society 51:243-69. 
Hughes, J.T.

1962 Lake Creek: A Woodland Site in the Texas Panhandle. Bulletin of the Texas Archeological Society 32:65-84.

Hughes, J.T. and P.S. Willey

1978 Archeology at Mackenzie Reservoir. Archeological Survey Report No. 24. Office of the State Archeologist, Texas Historical Commission, Austin.

Johnson, E.

1987 Cultural Activities and Interactions. In Lubbock Lake: Late Quaternary Studies on the Southern High Plains, edited by E. Johnson, pp120-58. Texas A\&M University Press. College Station.

Johnson, E. and V. Holliday

1986 The Archaic Period at Lubbock Lake. In Current Trends in Southern Plains Archaeology, edited by T.G. Baugh. Plains Anthropologist Memoir 21:7-54.

2004 Late Quaternary Environments of the Southern High Plains. In The Prehistory of Texas, edited by T. Perttula. Texas A\&M University Press. College Station.

Kelley, J.H.

1974 A Brief Resume of Artifacts Collected at Lubbock Lake Site prior to 1961. In History and Prehistory of the Lubbock Lake Site, edited by C.C. Black. The Museum Journal 15:43-78. West Texas Museum Association, Lubbock.

Krieger, A.

1947 Artifacts from the Plainview Bison Bed. Bulletin of the Geological Society of America 58:938-952.

Ladken, N.

1995 Analysis of Ceramics and Glass Seed beads. In Late Holocene Investigations at the Lubbock Lake Landmark. Vol. 2. The 1989 and 1990 Wprl. Edited by E. Johnson, pp313-30. Quaternary Research Center Series 8. Lubbock Lake Landmark, Museum of Texas Tech University.

Lintz, C.

2002 Radiocarbon Date from the Chalk Hollow Site: A Stratified Archaic-Early Ceramic Period Locale in Randall County, Texas. Oklahoma Archeology 50(3):14-45.

Machette, M.

1986 Calcium and Magnesium Carbonates. In Field and Laboratory Procedures Used in Soil Chronosequence Studies, edited by Michael J. Singer and Peter Janitzky, pp. 30-33. U.S. Geological Survey Bulletin 1648, United States Government Printing Office, Washington D.C.

Meltzer, D.J.

1991 Altithermal Archaeology and Paleoecology at Mustang Springs, on the Southern High Plains of Texas. American Antiquity 56:236-67.

Muhs, D.R. and V. Holliday

1995 Evidence of Active Dune Sand on the Great Plains in the 19th Century from Accounts of Early Explorers. Quaternary Research 43: 198-208. 
Neck, R.W.

1995 Molluscan Remains. In Stratigraphy and Paleoenvironments of Late Quaternary Valley Fills on the Southern High Plains, by Vance T. Holliday, pp. 59-67. Memoir 186. The Geological Society of America, Boulder.

Roberts, F.H.H

1942 Archaeological and Geological Investigations in the San Jon District, Eastern New Mexico. Smithsonian Miscellaneous Collections 3:1-39. Bureau of American Ethnology, Smithsonian Institution, Washington D.C.

Schoeneberger, P.J., D.A. Wysocki, E.C. Benham, and W.D. Broderson, (editors)

2002 Field Book for Describing and Sampling Soils. Version 2.0. Natural Resources Conservation Service, National Soil Survey Center, Lincoln, Nebraska.

Schulte, E.E. and B.G. Hopkins.

1996. Estimation of soil organic matter by weight by weight Loss-On-Ignition. p. 21-32. In: Soil Organic matter: Analysis and Interpretation. (ed.) F.R. Magdoff, M.A. Tabatabai and E.A.Hanlon, Jr. Special publication No. 46. Soil Science Society of America, Madison.

Sellards, E.

1938 Artifacts Associated with Fossil Elephant. Bulletin of the Geological Society of America 49:999-1010.

Sellards E.H., G.L. Evans, and G.E. Meade

1947 Fossil Bison and Associated Artifacts from Plainview, Texas. Bulletin of the Geological Society of America 58:927954.

Speer, R.

1990 History of the Plainview Site. In Guidebook to Quaternary History of the Llano Estacado, edited by V.T. Holliday and E. Johnson, pp. 79-92. Lubbock Lake Quaternary Research Series 2. Texas Tech University, Lubbock.

Texas Historical Commission Texas Archeological Sites Atlas accessed 2005.

Tomka, S.A.

2004 The Plainview Hike and Bike Trail Intensive Survey Scope of Work. Copy on file at the Center for Archaeological Research, The University of Texas at San Antonio.

Tunnell, C.D.

1964 Two Burials from the Jim Arnold Site in Northwest Texas. Bulletin of the Texas Archeological Society 35:83-94.

Turner, S.E., and T.R. Hester

1985 A Field Guide to Stone Artifacts of Texas Indians. Gulf Publishing.

Winsborough, B.

1995 Diatoms. In Stratigraphy and Paleoenvironments of Late Quaternary Valley Fills on the Southern High Plains, edited by V. Holliday, pp. 67-82. Geological Society of America Memoir 186. Geological Society of America, Boulder.

Word, J.H.

1991 The 1975 Field School of the Texas Archeological Society. Bulletin of the Texas Archeological Society 60:57-106. 



\section{APPENDIX A \\ DIATOM PALEOENVIRONMENTAL ANALYSIS OF SEDIMENTS FROM ARCHEOLOGICAL SITE 41HA1, IN PLAINVIEW, TEXAS}

Barbara M. Winsborough, $P h D$

Winsborough Consulting 



\section{Appendix A: Diatom Paleoenvironmental Analysis of Sediments from Archeological Site 41HA1, in Plainview, Texas}

\section{INTRODUCTION}

Diatoms are unicellular, microscopic, photosynthetic algae distinguished by the possession of a cell wall that is heavily impregnated with silica. Because this silica cell wall is resistant to destruction, diatoms are often preserved in sediments. Diatoms can be found living in a wide variety of habitats, including seeps, wet walls, damp soil, caves, springs, streams, ponds, lakes, wetlands, marshes, lagoons, estuaries, bogs, swamps, fens, ditches, canals, temporary pools, salt works, estuaries, bays, and oceans. Some diatom species are free-floating planktonic forms living much of their life suspended in the water column, and other species are benthic, either moving about or attached to a solid surface such as sand grain, pebble, rock, wood, rooted macrophyte, other algae, or floating mat.

Most diatoms are cosmopolitan in distribution - found in many parts of the world under similar environmental conditions, and many species have predictable environmental requirements and pollution tolerance. Therefore, water quality directly effects diatom species composition. This sensitivity and a life span of a few days, means that diatoms respond rapidly to significant changes in their environment. Unlike other algal groups, diatoms found in sediments can be identified to species level, and a large and growing body of literature exists on the range of ecological tolerance of many common species. This makes diatoms well suited for use in paleoenvironmental reconstruction. They can provide information about local habitats, and when examined in a temporal sequence they reflect both abrupt changes and longterm trends in hydrologic conditions.

Thirty-eight sediment samples, collected from three trenches associated with site 41HA1, at Plainview, Texas, were submitted to Winsborough Consulting for diatom paleoenvironmental analysis. Site 41HA1 is a Paleoindian bison kill site, dating from approximately 10,000 to 9800 BP. The trenches are thought to include soils from bench, floodplain, and draw channel deposits. This report describes the results of the diatom analysis. Because of the geologically young age of the sediments it can be assumed that the diatoms are all extant forms and that the ecological information provided by modern diatom studies can be used to interpret the paleoenvironment reflected by the diatom assemblages found in the samples.
About one cubic centimeter of dry sediment from each sample was processed. To reduce the amount of organic matter and remove soluble minerals, the samples were boiled in hydrogen peroxide and nitric acid. The rinsed material was mounted on glass slides and $22 \mathrm{~mm}$ square cover slips with Naphrax resin. Slides from each sample were scanned in their entirety at $1500 \mathrm{x}$ for diatoms, and all whole and broken diatoms were tabulated. The presence of phytoliths, testate protozoans, sponge spicules and other microfossils was also recorded.

\section{RESULTS AND DISCUSSION}

Diatoms were found in many of the samples from Trenches 10 and 11 (Tables A-1 and A-2) but almost none could be found in Trench 20 (Table A-3). The diatoms were heavily diluted with sediment, and many were broken. They were identified to the lowest possible level, and counted as an unidentified diatom fragment if the piece was too small to identify further. In all instances, the entire slide was scanned and all remains of diatoms, sponge spicules, testate protozoans, and phytoliths were recorded. There was some evidence of corrosion of the diatoms but many of the diatoms that were found are small, delicate species suggesting that selective dissolution of the diatom assemblage was probably not an important issue in determining the composition of the diatom assemblage recovered. Phytoliths were present in many of the samples that contained diatoms and their relative abundance was estimated roughly as few, common or abundant dependent on density and diversity of shape.

The diatom assemblage found in the trenches includes 52 taxa (Table A-4) that are typical of the kind that would have been present in habitats associated with Running Water Draw during the Holocene. Table A-4 is a comprehensive species list with authorship, including older names of taxa that have been renamed, to allow comparison with earlier literature. These diatoms are predominantly benthic taxa found in shallow aquatic habitats with macrophytic vegetation. Most of the diatoms are typically epiphytic on plants or other algae but some also move around on and through the sediment, or attach to sand grains and pebbles. The Aulacoseira spp. are the only truly planktonic diatoms found, but there were very few of them and the water depth need not have been more than a few meters for them to grow. They are able to grow in turbid water when light did not reach the bottom. 
One notable characteristic of the assemblage is the number of diatom genera, including Craticula, Denticula, Epithemia, Mastogloia, and Rhopalodia, whose species contain internal siliceous structures thought to provide additional support for the living protoplasm during times of osmotic stress. These species are found in habitats that dry out often or are reduced to a thin film of moisture. In addition to the aquatic species, some taxa such as Luticola mutica, Diadesmis brekkensis, Hantzschia amphioxys and Pinnularia borealis are true aerophils found in soils and damp or muddy habitats. There were quite a few cells of Hantzschia amphioxys in samples 10 and 11 the bottom two samples from trench 10 (Table A-1). This diatom was also consistently present, but in low numbers throughout trench 11 (Table A-2).

The diatom assemblage in the cores, taken as a whole is characteristic of standing or slow-flowing, somewhat alkaline water with a vegetated bottom and moderate to elevated salinity. The salts could have been carbonate, sulfate, or chloride. There were no acid water diatoms, and the $\mathrm{pH}$ was in the range of 7 to 8.5 . The water was no doubt shallow (no more than a few meters) to very shallow, and normally clear except during floods or other physical disturbances when it became muddy. The heavy dilution of the diatoms with sediment suggests that the source was a flood plain, or overbank deposit exposed to flooding from Running Water Draw. Another possibility is that the material came from a physically disturbed area on the margin of an aquatic habitat such as a marshy wetland or playa associated with the draw. Because of the small number of diatom cells found in most of the samples, any specific interpretation of long-term trends in water quality or quantity is impractical as is any specific estimate of the nutrient or pollution level of the water, but there was no indication of severely polluted conditions.

The paleoenvironmental interpretations of the present study are in agreement with previous studies of diatoms at archaeological sites on Running Water Draw, and along other draws on the Southern High Plains, that together span the entire Holocene (Tempere and Peragallo 1907-1915; Lohman 1936; Patrick 1938; Hohn and Hellerman 1961; Hohn 1975; Winsborough 1988; Meltzer 1991; Winsborough, 1995). The
Southern High Plains was a regional environment of springfed, freshwater lakes along the draws at the beginning of the Holocene. These lakes fluctuated seasonally (and over longer cycles) both in depth and in extent. Seasonal inputs of freshwater, followed by evaporative concentration, favored selection of robust, salt-tolerant species resistant to osmotic change. Besides seasonal fluctuations in water level, there was a gradual regional drying trend over the Holocene, with several short wetter intervals (Winsborough 1995).

An unexpected group of diatom remains were found in a few of the samples, specifically trench 11 , samples 11 (68$70 \mathrm{~cm})$ and, $12(70-72 \mathrm{~cm})$, and tr. 20, \#9 $(245 \mathrm{~cm})$. These species include the diatom Thalassionema nitzschioides, and an assortment of marine centric diatom fragments. There were also some marine silicoflagellates. T. nitzschioides is a common and widespread neritic, mesohaline or polyhaline, planktonic marine diatom found commonly in coastal bays and estuaries (Cooper 1995). How these diatoms arrived at the Plainview Site is very speculative.

It is possible that these saline species were growing in a coastal lagoon, salt marsh or estuary and their remains were incorporated as an impurity during salt collection. The diatoms would have been living on the surface of the salt crust or trapped in the evaporating brine and collected along with salt for use in curing bison meat. It is unlikely; however, that Indians would travel all the way to the coast for salt when it was available from nearby salt marshes. Another marginally more realistic scenario is that the bison picked up the marine algae at the coast during migrations and retained them in their fur until their death at Plainview. The same marine diatoms were found in an archaeological site in central Texas, also in early Holocene sediment associated with bison.

It was also considered that the marine planktonic diatoms might have been eroded from an older lacustrine formation. A search of this author's unpublished diatom species lists from late Quaternary lacustrine material, including the Lingos, Rita Blanca, Blanco, Mulberry Creek, and Ogallala Formations did not turn up any of these problem species. Further investigation will be necessary to resolve this issue. 


\section{References Cited}

Cooper, S.R.

1995 Diatoms in Sediment Cores From the Mesohaline Chesapeake Bay, U.S.A. Diatom Research, 10 (1): 39-89.

Hohn, M.H.

1975 The Diatoms. In Late Pleistocene Environments of the Southern High Plains, edited by F. Wendorf and J. Hester, pp. 197-200. Fort Burgwin Research Center Publication No. 9. Ranchos de Taos.

Hohn, M.H., and J. Hellerman

1961 The Diatoms. In Paleoecology of the Llano Estacado, compiled by Fred Wendorf, pp. 98-104. Fort Burgwin Research Center, No.1. Museum of New Mexico Press, Santa Fe.

Lohman, K.E.,

1936 Diatoms from Quaternary Lake Beds near Clovis, New Mexico. Journal of Paleontology 9:455-459.

Meltzer, D.J.

1991 Altithermal Archaeology and Paleoecology at Mustang Springs, on the Southern High Plains. American Antiquity $56: 236-267$

Patrick, R.,

1938 The Occurrence of Flints and Extinct Animals in Pluvial Deposits Near Clovis, New Mexico. Part V: Diatom Evidence From the Mammoth Pit. Proceedings of the Academy of Natural Sciences of Philadelphia 40:15-24.

Tempere, J.A., and H. Peragallo

1907-1915 Diatomees du Monde Entier, ed. 2, 30 fasc.: Arcachon, Grez-sur-Loing (S-et-M.)., fascicule 1-30, p. 1-480.

Winsborough, B.M.,

1988 Paleoecological Analysis of Holocene Algal Mat Diatomites Associated with Prehistoric Wells on the Texas High Plains. Paper presented at the 22nd Meeting of the South-Central Section of the Geological Society of America, Lawrence, Kansas.

Winsborough, B.M.,

1995 Diatoms. In Stratigraphy and Paleoenvironments of Late Quaternary Valley Fills on the Southern High Plains, by V. Holiday pp. 67-82. Geological Society of America Memoir 186. 
Table A-1. Absolute Abundance of Diatoms and Other Microfossils from Trench 10, Site 41HA1

\begin{tabular}{|c|c|c|c|c|c|c|c|c|c|c|}
\hline Sample \# & $2^{*}$ & $3^{*}$ & 4 & 5 & 6 & 7 & 8 & 9 & 10 & 11 \\
\hline Depth $(\mathrm{cm})$ & $-6-9$ & $-4-6$ & $3-5$ & $9-11$ & $16-18$ & $22-23$ & $30-32$ & $40-42$ & $55-57$ & $70-72$ \\
\hline $\begin{array}{l}\text { Achnanthes } \\
\text { biassolettiana }\end{array}$ & & & & & 3 & & & & & \\
\hline Achnanthes sp. & & & & & 1 & & & & & \\
\hline $\begin{array}{l}\text { Achnanthidium } \\
\text { minutissimum }\end{array}$ & & & & 2 & 6 & & & & & \\
\hline \multicolumn{11}{|l|}{ Amphora ovalis } \\
\hline \multicolumn{11}{|l|}{ Amphora libyca } \\
\hline $\begin{array}{l}\text { Anomoeoneis } \\
\text { sphaerophora }\end{array}$ & & & & & & & & 1 & & \\
\hline $\begin{array}{l}\text { Aulacoseira cf. } \\
\text { crenulata }\end{array}$ & & & & & & & 7 & 1 & & \\
\hline Aulacoseira granulata & & & & & 4 & & & & & \\
\hline \multicolumn{11}{|l|}{ Bacillaria paradoxa } \\
\hline \multicolumn{11}{|l|}{ Caloneis bacillum } \\
\hline Cocconeis placentula & & & & & 2 & & & & & \\
\hline Craticula cuspidata & & & & & & & & 1 & & \\
\hline Craticula halophila & & & & & & & & & 3 & 6 \\
\hline \multicolumn{11}{|l|}{ Cymbella cymbyformis } \\
\hline Cymbella triangulum & & & & & 1 & & & & & \\
\hline Cymbella sp. & & & & & & & & 1 & & \\
\hline Denticula elegans & & & & & 1 & & & & & \\
\hline Denticula kuetzingii & & & & & & 2 & & 5 & & \\
\hline \multicolumn{11}{|l|}{ Diadesmis brekkaensis } \\
\hline Diploneis elliptica & & & & & 2 & 1 & & & & \\
\hline \multicolumn{11}{|l|}{ Diploneis ovalis } \\
\hline \multicolumn{11}{|l|}{ Diploneis sp. } \\
\hline $\begin{array}{l}\text { Encyonema } \\
\text { evergladianum }\end{array}$ & & & 6 & & & & & & & \\
\hline Encyonema silesiaca & & & & & & 1 & & & & \\
\hline $\begin{array}{l}\text { Encyonopsis } \\
\text { microcephala }\end{array}$ & & & 1 & 1 & & & & & & \\
\hline \multicolumn{11}{|l|}{ Epithemia adnata } \\
\hline Epithemia argus & & & & 1 & 3 & & & & & \\
\hline Epithemia turgida & & & & & 33 & 3 & 22 & 18 & & \\
\hline Eunotia pectinalis & & & & & 1 & & & & & \\
\hline Fragilaria capucina & & & & & 5 & & 4 & & & \\
\hline \multicolumn{11}{|l|}{ Fragilaria fasciculata } \\
\hline Fragilaria leptostauron & & & & & 1 & 2 & 2 & 3 & & \\
\hline Fragilaria nitida & & & & & & 1 & & & & \\
\hline Fragilaria nitzschioides & & & & & & & & 1 & & \\
\hline Fragilaria ulna & & & & & 24 & & 2 & 2 & & \\
\hline $\begin{array}{l}\text { Gomphonema } \\
\text { angustatum }\end{array}$ & & & & & 1 & & & & & \\
\hline
\end{tabular}


Table A-1. Continued...

\begin{tabular}{|c|c|c|c|c|c|c|c|c|c|c|}
\hline Sample \# & $2^{*}$ & $3^{*}$ & 4 & 5 & 6 & 7 & 8 & 9 & 10 & 11 \\
\hline Depth $(\mathrm{cm})$ & $-6-9$ & $-4-6$ & $3-5$ & $9-11$ & $16-18$ & $22-23$ & $30-32$ & $40-42$ & $55-57$ & $70-72$ \\
\hline \multicolumn{11}{|l|}{ Gomphonema parvulum } \\
\hline Gomphonema sp. & & & & & & & & 1 & & \\
\hline Hantzschia amphioxys & & & 1 & & 1 & & & 2 & 24 & 107 \\
\hline \multicolumn{11}{|l|}{ Luticola mutica } \\
\hline \multicolumn{11}{|l|}{ Mastogloia sp. } \\
\hline \multicolumn{11}{|l|}{ Navicula oblonga } \\
\hline \multicolumn{11}{|l|}{ Nitzschia amphibia } \\
\hline Nitzschia frustulum & & & & & 1 & & & 1 & & \\
\hline \multicolumn{11}{|l|}{$\begin{array}{l}\text { Pseudostaurosira } \\
\text { brevistriata }\end{array}$} \\
\hline Pinnularia borealis & & & & & 2 & & & & & \\
\hline Pinnularia sp. & & & & & 1 & & & & & 2 \\
\hline \multicolumn{11}{|l|}{ Rhopalodia brebissonii } \\
\hline Rhopalodia gibba & & & 1 & & & & & 5 & & \\
\hline Rhopalodia gibberula & & & & & 1 & & 3 & & & \\
\hline \multicolumn{11}{|l|}{ Sellaphora pupula } \\
\hline $\begin{array}{l}\text { Stauroneis } \\
\text { phoenicentron }\end{array}$ & & & & & & & & & 1 & 4 \\
\hline \multicolumn{11}{|l|}{$\begin{array}{l}\text { Thalassionema } \\
\text { nitzschioides }\end{array}$} \\
\hline \multicolumn{11}{|l|}{$\begin{array}{l}\text { Marine/saline centric } \\
\text { diatom fragments }\end{array}$} \\
\hline Total \# of diatoms & 0 & 0 & 9 & 4 & 94 & 10 & 40 & 42 & 28 & 119 \\
\hline \multicolumn{11}{|l|}{ Silicoflagellates } \\
\hline Testate protozoans & & & & & few & few & few & few & & \\
\hline $\begin{array}{l}\text { Unidentified diatom } \\
\text { fragments }\end{array}$ & & & & 2 & 129 & 15 & 23 & 11 & 1 & 3 \\
\hline Sponge spicules & & & & & & & few & & & \\
\hline Phytoliths & none & few & few & abun & abun & few & abun & abun & abun & abun \\
\hline
\end{tabular}

${ }^{*}$ No diatoms were found in samples 2 and 3. 
Table A-2. Absolute Abundance of Diatoms and Other Microfossils from Trench 11, Site 41HA1

\begin{tabular}{|c|c|c|c|c|c|c|c|c|c|c|c|c|}
\hline Sample \# & 1 & 2 & 3 & 4 & 5 & 6 & 7 & 8 & 9 & 10 & 11 & 12 \\
\hline Depth $(\mathrm{cm})$ & $5-6$ & $10-12$ & $15-17$ & $20-22$ & $28-30$ & $35-37$ & $41-43$ & $45-47$ & $50-52$ & $60-62$ & $68-70$ & $70-72$ \\
\hline \multicolumn{13}{|l|}{$\begin{array}{l}\text { Achnanthes } \\
\text { biassolettiana }\end{array}$} \\
\hline \multicolumn{13}{|l|}{ Achnanthes sp. } \\
\hline \multicolumn{13}{|l|}{$\begin{array}{l}\text { Achnanthidium } \\
\text { minutissimum }\end{array}$} \\
\hline Amphora libyca & & & & & & & 1 & & & & & 1 \\
\hline Amphora ovalis & & & & & & & & & & 1 & & \\
\hline \multicolumn{13}{|l|}{$\begin{array}{l}\text { Anomoeoneis } \\
\text { sphaerophora }\end{array}$} \\
\hline Aulacoseira cf. crenulata & & & 4 & & & & & & 1 & & & 7 \\
\hline \multicolumn{13}{|l|}{ Aulacoseira granulata } \\
\hline Bacillaria paradoxa & & & & & & & & & & & & 1 \\
\hline Caloneis bacillum & & 1 & & & & & & & & & & \\
\hline Cocconeis placentula & & & & & & & & & & & 1 & \\
\hline Craticula cuspidata & & & 1 & & & & & & & & & \\
\hline \multicolumn{13}{|l|}{ Craticula halophila } \\
\hline Cymbella cymbiformis & & & & & & & 1 & & & & & \\
\hline \multicolumn{13}{|l|}{ Cymbella triangulum } \\
\hline Cymbella sp. & & & & & & & & & 2 & & & \\
\hline Denticula elegans & & & & & & & & & & & & 1 \\
\hline \multicolumn{13}{|l|}{ Denticula kuetzingii } \\
\hline Diadesmis brekkaensis & & & & & & 1 & & & & & & \\
\hline Diploneis elliptica & & & & & & & & 1 & & & & \\
\hline Diploneis ovalis & & & 1 & & & & & & & & & \\
\hline Diploneis sp. & & & & & & & & & & 1 & 1 & \\
\hline \multicolumn{13}{|l|}{$\begin{array}{l}\text { Encyonema } \\
\text { evergladianum }\end{array}$} \\
\hline \multicolumn{13}{|l|}{ Encyonema silesiaca } \\
\hline \multicolumn{13}{|l|}{$\begin{array}{l}\text { Encyonopsis } \\
\text { microcephala }\end{array}$} \\
\hline Epithemia adnata & 1 & & 1 & 1 & & & & & & & & \\
\hline Epithemia argus & & & 1 & & 1 & & & & & & & 1 \\
\hline Epithemia turgida & 2 & 19 & 22 & 3 & 1 & 4 & 1 & 7 & 4 & 26 & 11 & 10 \\
\hline Eunotia pectinalis & & & & & & & & & 2 & 1 & 1 & \\
\hline \multicolumn{13}{|l|}{ Fragilaria capucina } \\
\hline Fragilaria fasciculata & & & & & & & & & & & 1 & 10 \\
\hline Fragilaria nitida & & 1 & & & & & & & & & & \\
\hline Fragilaria nitzschioides & & 1 & & & & 5 & & 2 & & & & 2 \\
\hline
\end{tabular}


Table A-2. Continued...

\begin{tabular}{|c|c|c|c|c|c|c|c|c|c|c|c|c|}
\hline Sample \# & 1 & 2 & 3 & 4 & 5 & 6 & 7 & 8 & 9 & 10 & 11 & 12 \\
\hline Depth $(\mathrm{cm})$ & $5-6$ & $10-12$ & $15-17$ & $20-22$ & $28-30$ & $35-37$ & 41-43 & $45-47$ & $50-52$ & $60-62$ & $68-70$ & $70-72$ \\
\hline Fragilaria ulna & 3 & 6 & 6 & & & & 1 & & 2 & 7 & & 4 \\
\hline $\begin{array}{l}\text { Gomphonema } \\
\text { angustatum }\end{array}$ & & 3 & 2 & & & & & & & 2 & & \\
\hline Gomphonema parvulum & & & 1 & & & & & & & & & \\
\hline Gomphonema sp. & & & & & & 1 & & & & & & \\
\hline Hantzschia amphioxys & 1 & 7 & 8 & & 2 & 2 & & 5 & & 6 & 3 & 4 \\
\hline Luticola mutica & & & & & & 1 & & & & & & \\
\hline Mastogloia sp. & & & & & & & & & 2 & & & \\
\hline Navicula oblonga & 2 & & 2 & & & & & 1 & & & & 1 \\
\hline Nitzschia amphibia & & & & & & & & & & 2 & & \\
\hline Nitzschia frustulum & & 3 & & & & 1 & & & & & & \\
\hline Nitzschia sp. & & & & & & & & & & 5 & & \\
\hline \multicolumn{13}{|l|}{ Pinnularia borealis } \\
\hline Pinnularia sp. & & 1 & & & & & & 2 & & & & \\
\hline $\begin{array}{l}\text { Pseudostaurosira } \\
\text { brevistriata }\end{array}$ & & & 2 & & & & & & & 4 & 2 & 2 \\
\hline $\begin{array}{l}\text { Pseudostaurosirella } \\
\text { leptostauron }\end{array}$ & 2 & 10 & 12 & 1 & & & 2 & 3 & & 5 & 3 & 3 \\
\hline Rhopalodia brebissonii & & & 1 & & & & & & & & & \\
\hline Rhopalodia gibba & 1 & 9 & 7 & & & 3 & & & & 8 & 1 & 3 \\
\hline \multicolumn{13}{|l|}{ Rhopalodia gibberula } \\
\hline \multicolumn{13}{|l|}{ Sellaphora pupula } \\
\hline \multicolumn{13}{|l|}{$\begin{array}{l}\text { Stauroneis } \\
\text { phoenicentron }\end{array}$} \\
\hline $\begin{array}{l}\text { Thalassionema } \\
\text { nitzschioides }\end{array}$ & & & & & & & & & & & 4 & 70 \\
\hline $\begin{array}{l}\text { Marine/saline centric } \\
\text { diatom fragments }\end{array}$ & & & & & & & & & & & & 25 \\
\hline Total \# of diatoms & 12 & 61 & 71 & 5 & 4 & 18 & 6 & 21 & 13 & 68 & 23 & 145 \\
\hline Silicoflagellates & & & & & & & & & & & & 6 \\
\hline Testate protozoans & abun & few & com & few & & & & few & few & com & com & few \\
\hline $\begin{array}{l}\text { Unidentified diatom } \\
\text { fragments }\end{array}$ & 3 & 6 & 19 & & 1 & 5 & & & 3 & 14 & 12 & 1 \\
\hline Sponge spicules & & & & & & & & few & & & & \\
\hline Phytoliths & abun & com & com & few & few & abun & few & abun & few & com & abun & abun \\
\hline
\end{tabular}




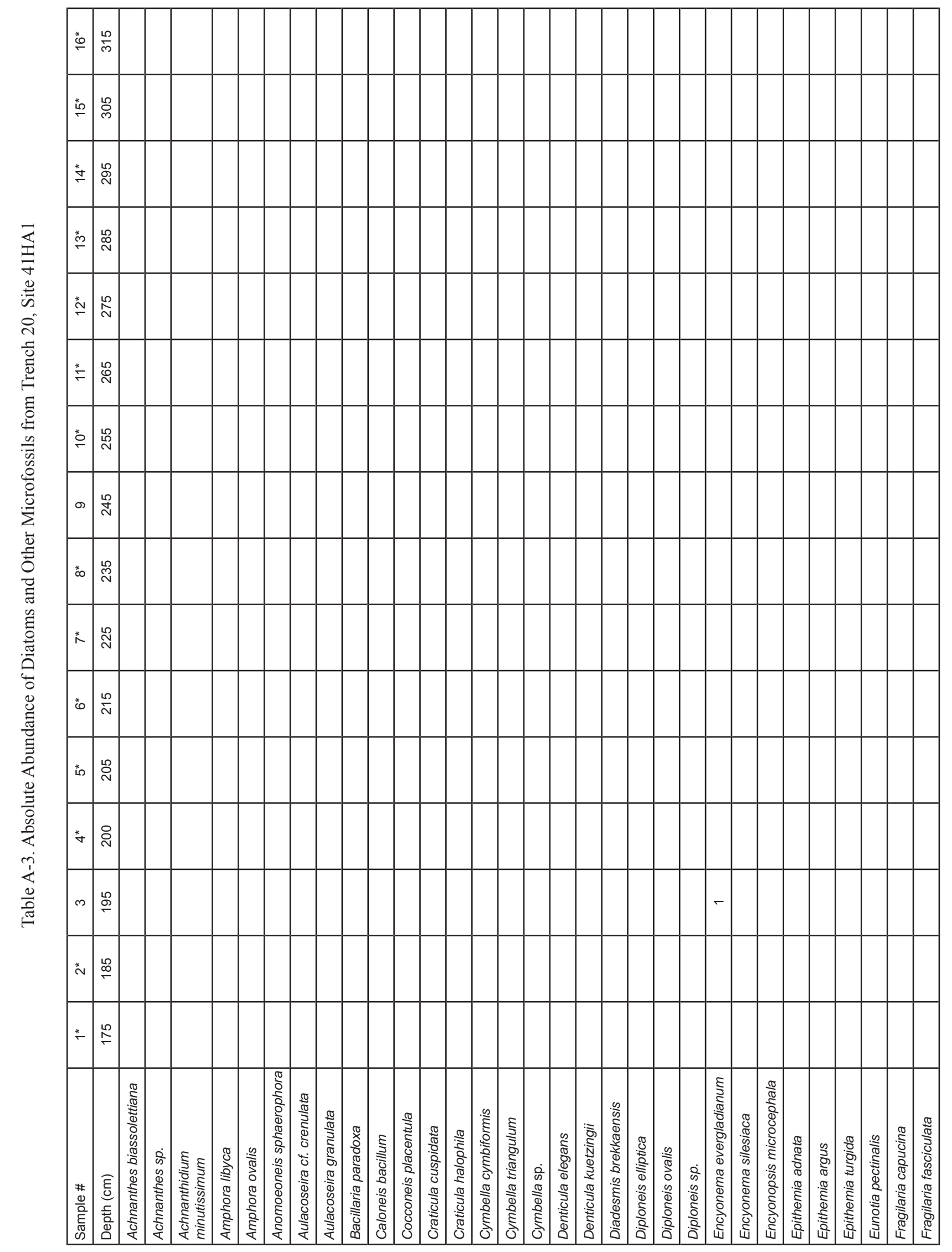




\section{$\stackrel{*}{*}$}

离

$\pm \stackrel{\leftrightarrow}{*}$

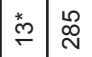

$\pm \stackrel{2}{\sim}$

$* \stackrel{\circ}{*}$

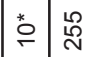

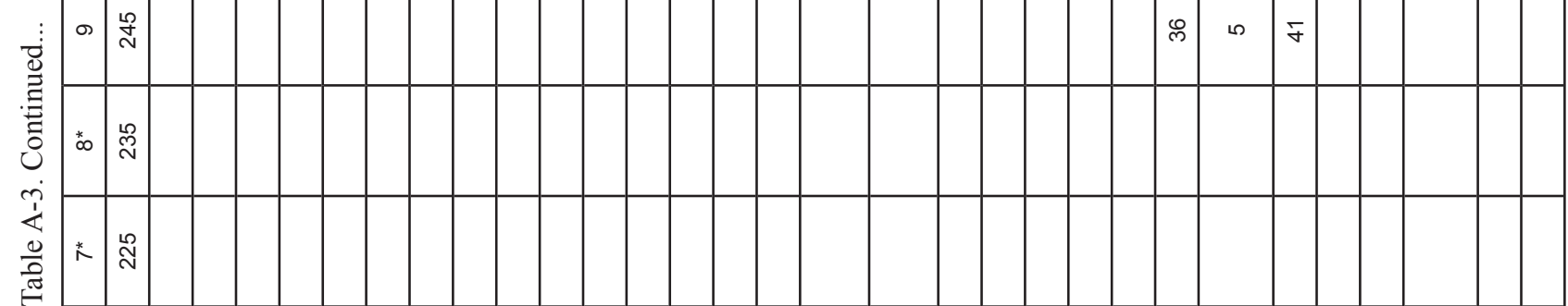

$\approx \stackrel{\circ}{N}$

เ

$*$ ㅇำ

$\infty \stackrel{\circ}{\circ}$

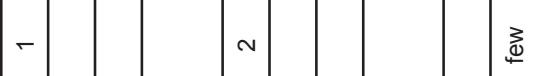

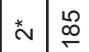

$\approx \stackrel{2}{\circ}$

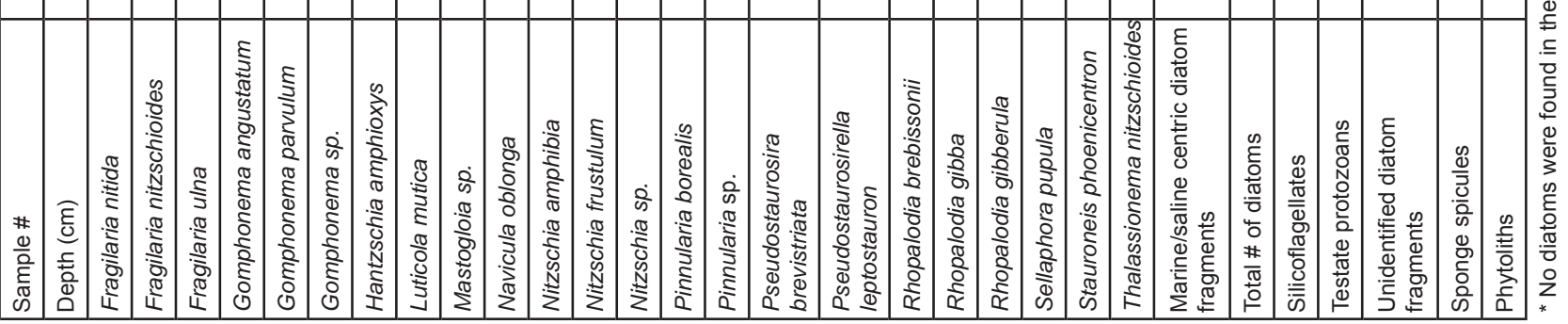


Table A-4. Master List of Diatom Taxa from 41HA1 with Authorship and Alternative Names

\begin{tabular}{|c|c|}
\hline Achnanthes biassolettiana Grunow & Epithemia turgida (Ehrenberg) Kützing \\
\hline Achnanthes sp. & Eunotia pectinalis (Müller) Rabenhorst \\
\hline Achnanthidium (Achnanthes) minutissimum (Kützing) Czarnecki & Fragilaria capucina Desmazieres \\
\hline Amphora ovalis (Kützing) Kützing & Fragilaria fasciculata (Agardh) Lange-Bertalot \\
\hline Amphora libyca Ehrenberg & Fragilaria leptostauron (Ehrenberg) Hustedt \\
\hline Anomoeoneis sphaerophora (Ehrenberg) Pfitzer & Fragilaria nitida Héribaud \\
\hline Aulacoseira (Melosira) cf. crenulata (Ehrenberg) Thwaites & Fragilaria nitzschioides Grunow \\
\hline Aulacoseira (Melosira) granulata (Ehrenberg) Simonsen & Fragilaria (Synedra) ulna (Nitzsch) Lange-Bertalot \\
\hline Bacillaria paxillifer (paradoxa)(O. Müller) Hendey & Gomphonema angustatum (Kützing) Rabenhorst \\
\hline Caloneis bacillum (Grunow) Cleve & Gomphonema parvulum (Kützing) Grunow \\
\hline Cocconeis placentula Ehrenberg & Gomphonema sp. \\
\hline Craticula (Navicula) cuspidata (Kützing) D.G. Mann & Hantzschia amphioxys (Ehrenberg) Grunow \\
\hline Craticula (Navicula) halophila (Grunow) D.G. Mann & Luticola (Navicula) mutica (Kützing) D.G. Mann \\
\hline Cymbella cymbyformis Agardh & Mastogloia sp. \\
\hline Cymbella triangulum (Ehrenberg) Cleve & Navicula oblonga Kützing \\
\hline Cymbella sp. & Nitzschia amphibia Grunow \\
\hline Denticula elegans Kützing & Nitzschia frustulum (Kützing) Grunow \\
\hline Denticula kuetzingii Grunow & Pseudostaurosira (Fragilaria) brevistriata (Grunow) Williams \& Round \\
\hline Diadesmis (Navicula) brekkaensis (Petersen) D.G. Mann & Pinnularia borealis Ehrenberg \\
\hline Diploneis elliptica (Kützing) Cleve & Pinnularia sp. \\
\hline Diploneis ovalis & Rhopalodia brebissonii Krammer \\
\hline Diploneis sp. & Rhopalodia gibba (Ehrenberg) O. Müller \\
\hline Encyonema evergladianum Krammer & Rhopalodia gibberula (Ehrenberg) O. Müller \\
\hline Encyonema silesiacum (Bleisch in Rabenhorst) Mann & Sellaphora (Navicula) pupula (Kützing) D.G. Mann \\
\hline Encyonopsis (Cymbella) microcephala (Grunow) Krammer & Stauroneis phoenicentron (Nitzsch) Ehrenberg \\
\hline Epithemia adnata (Kützing) Brébisson & Thalassionema nitzschioides (Grunow) Hustedt \\
\hline Epithemia argus Grunow & \\
\hline
\end{tabular}




\title{
APPENDIX B \\ QUARTZ OPTICAL DATING REPORT
}

\author{
Sheffield Centre for Drylands Research
}

Tables and figures numbered in Appendix B are independent of those found in the body of this report. All references to tables and figures are exclusive to the Quartz Optical Dating Report. 



\section{Sheffisld}

Centre for

Internationat

Dryltivids

Research

\section{Quartz Optical Dating Report}

\author{
$23^{\text {rd }}$ January, 2007
}

Plainview site (41HA1), Texas, USA

\begin{abstract}
Optical luminescence dating both at the single grain level was applied to coarse quartz grains extracted from two samples from the Plainview site (41HA1), Texas. These measurements showed possible incomplete resetting of sediment prior to burial and post-depositional disturbance. Through use of single grain measurements and statistical data analysis it is believed that the burial age component of the samples has been isolated. Thus, best estimates of the sample's burial age range from $13850 \pm 700$ years (SHFD06115) to $7530 \pm 450$ years (Shfd06116).
\end{abstract}

1. Introduction: Two samples in opaque PVC tubing from the Plainview site, Texas, USA were submitted for luminescence dating by Dr. Charles Frederick. All luminescence work was carried out at the Sheffield Centre for International Drylands Research (SCIDR) luminescence laboratory. The samples are assumed not to have been exposed to sunlight during sampling or transportation to the laboratory. Upon arrival, each sample was allocated a Sheffield lab number (Table 1). This report provides a brief summary of the procedures employed and results obtained for samples.

\begin{tabular}{cccccc}
\hline Lab No. & $\begin{array}{c}\text { Field } \\
\text { Reference }\end{array}$ & $\begin{array}{c}\text { Latitude } \\
\left({ }^{\circ} \mathrm{N}\right)\end{array}$ & $\begin{array}{c}\text { Longitude } \\
\left({ }^{\circ} \mathrm{W}\right)\end{array}$ & $\begin{array}{c}\text { Altitude } \\
(\mathrm{m})\end{array}$ & $\begin{array}{c}\text { Sampling Depth } \\
(\mathrm{cm} \text { below surface })\end{array}$ \\
Shfd06115 & OSL1 & $34^{\circ} 10^{\prime} 50^{\prime \prime}$ & $101^{\circ} 44^{\prime} 36^{\prime \prime}$ & 1023 & 305 \\
Shfd06116 & OSL2 & $34^{\circ} 10^{\prime} 50^{\prime \prime}$ & $101^{\circ} 44^{\prime} 36^{\prime \prime}$ & 1023 & 130 \\
\hline
\end{tabular}

Table 1. Sample descriptive data.

In order to derive an optically stimulated luminescence (OSL) age both the palaeodose (De - the amount of absorbed dose since the sample was buried) and the dose rate (the estimated radiation flux for the sedimentary bodies) have to be determined. Aitken (1998) gives a detailed explanation of both these parameters. To calculate an age, the palaeodose (expressed in Grays) is divided by the annual dose rate (Grays/yr). An inherent assumption in these age calculations is that the sediment was fully reset or 'bleached' by exposure to sunlight during the last transport event or whilst in situ prior to burial and that no post-depositional sediment disturbance has occurred. As part of this investigation, efforts have been taken to establish if these sediments have been bleached or disturbed by, for example, bioturbation. As the OSL 
signal measured with a standard aliquot is an average of 2000 grains the true distribution of De values within a sample may be masked. This is of particular significance in heterogeneously dosed samples (e.g. poorly reset/bleached) in which grains with a high De signal will dominated the signal at the expense of grains containing a true burial De. Measurement of the accumulated dose from individual grains obviates this problem. Thus this latter single grain approach was adopted for this study.

2. Dose Rate Analysis: Naturally occurring potassium (K), thorium (Th) and uranium (U) are the main contributors of dose to sedimentary quartz. The concentrations of these elements were determined by inductively coupled plasma mass spectrometry (ICP) at SGS laboratories Ontario Canada and converted to annual dose rates using data from Adamiec and Aitken (1998), Marsh et al. (2002), and Aitken (1988). This incorporates attenuation factors relating to sediment grain sizes used, density and palaeomoisture. Attenuation of dose by moisture used the present-day moisture values as measured in the laboratory with a $\pm 2 \%$ error to incorporate seasonal and longer-term fluctuations in moisture which the samples may have endured since burial. The contribution to dose rates from cosmic sources were calculated using the expression published in Prescott and Hutton (1994). The dose rates calculated are based on analyses of the sediment sampled at the present day. As no stratigraphic information with regard to the thickness of the units sampled was provided, it has been assumed that the samples formed part of a thick homogeneous unit with no gamma contribution (other than from cosmogenic sources) being received by the samples from other unsampled sedimentary units. Additionally this assumption is only valid if no movement and/or reprecipitation of the key elements has taken place since sediment burial. Further analysis would have to be undertaken to establish whether the latter is true and if radioactive disequilibrium is present in the dose rate.

(a)

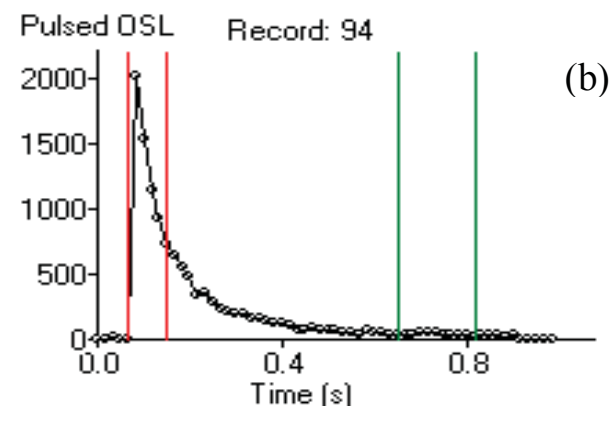

(b)

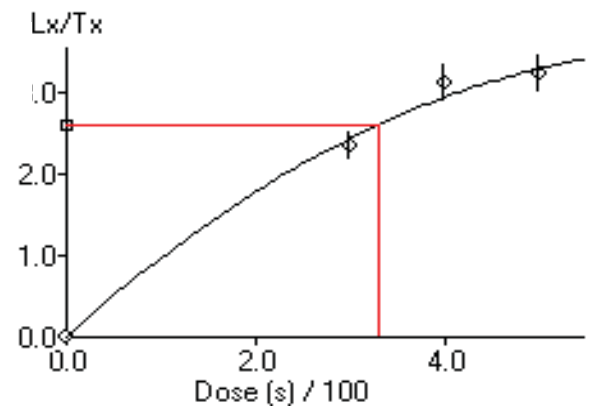

Figure 1: Examples of single grain OSL data for sample Shfd06116 (a) OSL decay of naturally acquired signal and (b) SAR growth curves.

3. Palaeodose Determination: The samples were prepared under subdued red lighting following the procedure to extract and clean quartz outlined in Bateman and Catt (1996). Prepared aliquots of the samples were taken from within a maximum size range of 90-125 $\mu \mathrm{m}$. Both samples then underwent measurements at the single grain level using a Risø TL DA-15 single grain laser luminescence reader with radiation doses administered using a calibrated ${ }^{90}$ strontium beta source. Grains were mounted in $300 \mu \mathrm{m}$

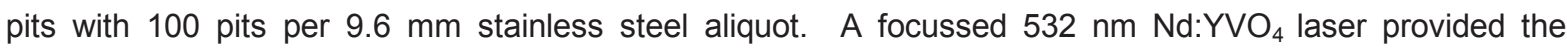
stimulation and luminescence detection was through a Hoya U-340 filter. The samples were analysed using the single aliquot regenerative (SAR) approach (Murray and Wintle 2000), in which an interpolative growth curve is constructed using data derived from repeated measurements of a single grains given various laboratory irradiations (Figure 1). 
Within the SAR protocol a preheat of $240{ }^{\circ} \mathrm{C}$ for 10 seconds prior to OSL measurement was used to remove unstable signal generated by laboratory irradiations. This preheat was derived experimentally using a dose recovery test with a range of preheat temperatures (after Murray and Wintle, 2003). As Figure 2 shows the $240^{\circ} \mathrm{C}$ for 10 preheat recovers the $9.75 \mathrm{~Gy}$ laboratory dose within errors and has recycling ratios within $\pm 10 \%$. The last irradiation dose replicated the first and was used to check that any sensitivity changes caused by repeated measurement and heating had been monitored and corrected for by the SAR protocol.

(a)

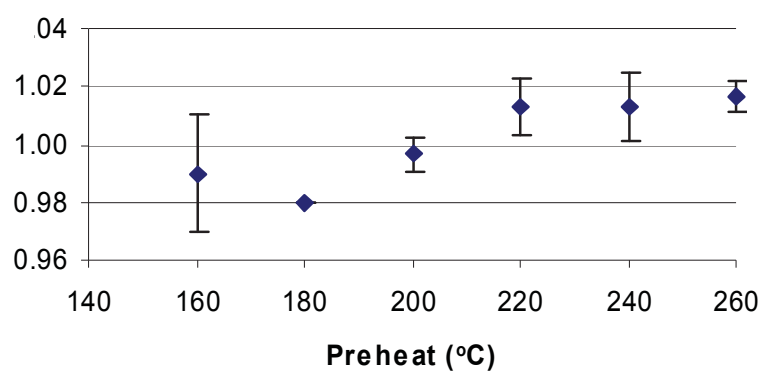

(b)

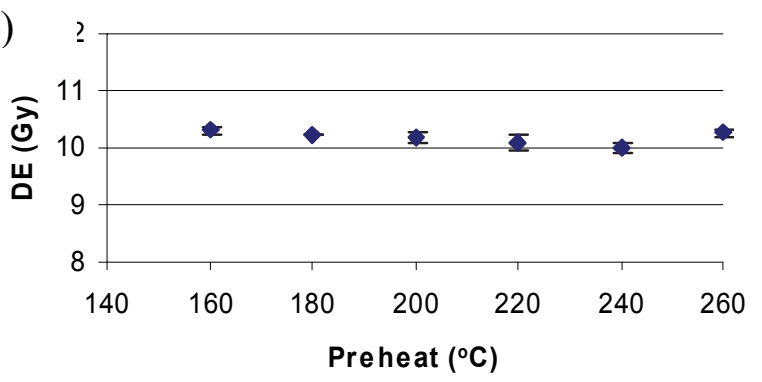

Figure 2. Results of Dose recovery test on Shfd06016 used to determine appropriate preheat for SAR protocol. (a) recycling ratio of different preheats; (b) results of different preheats recovering 9.75 Gy laboratory dose.

With all single grain OSL analysis many grains exhibit insufficient OSL signal to be utilised and/or are too poorly behaved for the De to be accurately measured. De values from individual grains were only accepted where their recycling ratio was $1 \pm 0.20$, they exhibited good growth with dose and the error on the test dose was less than $20 \%$. For sample Shfd06115, of the 1000 grains measured only $7 \%$ yielded grains which met these criteria. For sample Shfd06116 of the 300 grains measured $19 \%$ yielded grains which met these criteria.

4. Sedimentary bleaching behaviour: The effects of incomplete bleaching of the sediment during the last period of transport or exposure in situ can be profound. Typically, poorly bleached sediments retain a significant level of residual signal from previous phases of sedimentary cycling, leading to inherent inaccuracies in the calculation of a palaeodose value. This is difficult to establish with any certainty from OSL data and should be taken into consideration with the site stratigraphy. By plotting the replicate data for each sample as a probability density function some assessment of whether older or younger material has been included in the sample measurements can be made (Figure 3, Appendix 1). In principle a well bleached unpost-depositionally disturbed sample should have replicate palaeodose (De) data which is normally distributed and highly reproducible (See Bateman et al. 2003, Fig 3). Where post-depositional disturbance or incomplete bleaching prior to sample burial has occurred skewing of this distribution may occur and/or replicate reproducibility may be lower (Bateman et al 2007). In the case of poorly bleached material skewing should be evident with a high De tail (e.g. Olley et al. 2004). 

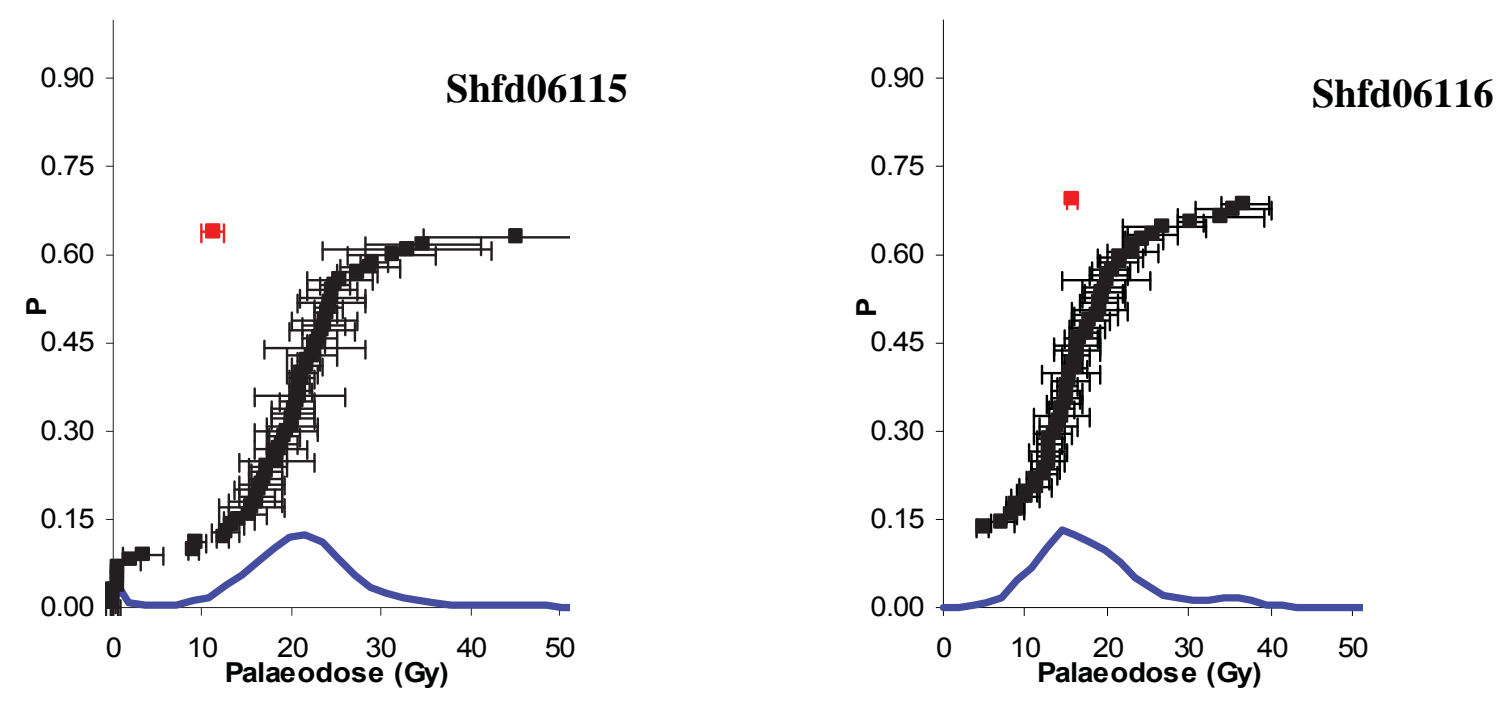

Figure 3: Combined probability density functions for single grains showing degree of inter-aliquot scatter. Also plotted are individual grain De (black) and the unweighted mean De (red).

As Figure 3 shows the single grain data distributions from both samples differ. Sample Shfd06115 is dominated by a normal, albeit broad De distribution with an over-dispersion value of $70 \%$. This sample, however, also displays a secondary cluster of De values at or near zero dose which accounts for $5 \%$ of the grains measured. Whilst some of these grains may be accountable by instrumental error it has been argued that where significant numbers of zero dose grains have been measured this in indicative of grains which have recently been exhumed and returned to depth by, for example, bioturbation (see Heimsath 2002; Bateman et al. 2007). Even without considering this secondary cluster of De values the De distribution is much broader than would be expected for a well-bleached undisturbed sediment. Sample Shfd06116 has a skewed De distribution with a tail of high De values and an over-dispersion value of $35.7 \%$. This could either be due to incomplete bleaching (OSL resetting) prior to burial or upward movement of older material postdepositionally.

Thus from an OSL data perspective post-depositional disturbance of the sediments associated with both the samples cannot be ruled out and careful consideration of this data in relation to available stratigraphic information is recommended.

5. Age Calculation: In order to try and produce absolute burial OSL ages for the two samples it has been assumed that the De values associated with the highest probability peak reflect the true burial De value. Tus De values from grains falling outside of two standard deviations of the mean have been excluded from further calculations and a single weighted mean value De was calculated with the weighting factors taking into account both the variation between each De value and also the associated error values for each grain. Ages are quoted in years from the present day (2007) and are presented with one sigma confidence intervals which incorporate systematic uncertainties with the dosimetry data, uncertainties with the palaeomoisture content and errors associated with the De determination (Table 2). 
Table 2. Summary of results.

\begin{tabular}{ccccccc}
\hline & \multicolumn{5}{c}{ Radioactivity Data } & \multicolumn{3}{c}{ Dosimetry Data } \\
\hline Lab Code & $\begin{array}{c}\mathbf{U} \\
(\mathrm{PPM})\end{array}$ & $\begin{array}{c}\text { Th } \\
(\mathrm{PPM})\end{array}$ & $\begin{array}{c}\mathbf{R b} \\
(\mathrm{PPM})\end{array}$ & $\begin{array}{c}\mathbf{K} \\
(\%)\end{array}$ & $\begin{array}{c}\mathbf{D}_{\text {cosmic }}{ }^{+} \\
\left(\mu \mathrm{G} / \mathrm{a}^{-1}\right)\end{array}$ & Moisture (\%) \\
\hline Shfd06115 & 0.8 & 2.2 & 38 & 1.05 & $169 \pm 8$ & $5.64 \pm 2$ \\
Shfd06116 & 1.31 & 4.8 & 45.6 & 1.16 & $109 \pm 5$ & $9.55 \pm 2$ \\
\hline
\end{tabular}

Table 2. Summary of results, continued

\begin{tabular}{lcccccccc}
\hline Lab Code & $\begin{array}{c}\text { Field } \\
\text { Ref. }\end{array}$ & $\begin{array}{c}\text { Depth } \\
(\mathbf{c m})\end{array}$ & $\begin{array}{c}\text { Total No. } \\
\text { Grains } \\
\text { Measured }\end{array}$ & $\begin{array}{c}\text { Usable } \\
\text { Grains }\end{array}$ & $\begin{array}{c}\text { Zero } \\
\text { Grains } \\
(\%)\end{array}$ & $\begin{array}{c}\text { Single Grain } \\
\text { De }^{*} \\
(\mathrm{~Gy})\end{array}$ & $\begin{array}{c}\text { Dose rate }^{\dagger} \\
\left(\mu \mathrm{Gy}^{-1}\right)\end{array}$ & $\begin{array}{c}\text { Single Grain } \\
\text { Age } \\
(\mathrm{yrs})\end{array}$ \\
\hline Shfd06115 & OSL1 & 305 & 1000 & 66 & 5 & $20.70 \pm 0.42$ & $1494 \pm 70$ & $\mathbf{1 3 , 8 5 0 \pm 7 0 0}$ \\
Shfd06116 & OSL2 & 130 & 300 & 56 & 0 & $15.16 \pm 0.48$ & $1759 \pm 77$ & $\mathbf{7 , 5 3 0 \pm 4 5 0}$ \\
\hline
\end{tabular}

6. Results and Conclusions: Table 2 provides a summary of dosimetry, alongside the palaeodose and calculated age for samples Shfd06115 and Shfd06116. Grain specific data for each sample is included in appendix 1. Single grain ages range from $13850 \pm 700$ years (Shfd06115) to $7530 \pm 450$ years (Shfd06116). In terms of reliability, the OSL signal for the samples has not gone into saturation (Fig 1a) and ages do increase in antiquity with depth. However, in the light of the single grain reproducibility results (section 5) the ages may still contain an antecedent/disturbed signal. As the measurements are at the single grain level (in which grains are either fully bleached or completely unbleached on burial) and as attempts have been made to statistically isolate the dominant De component we believe that the calculated ages from the single grain data should be near-true burial ages. However, more rigorous comparison of this data with an independent chronology and in the context of site stratigraphy is needed to validate this assertion.

Dr Mark D. Bateman

*Estimated from weighted mean (by inverse variance) of single grain SAR measurements.

+ Cosmic dose is calculated as a linear decay curve at depths below $50 \mathrm{~cm}$. Above this depth, errors in calculation may lead to an overestimation of palaeodose value.

${ }^{\dagger}$ Total Dose is attenuated for grain size, density and moisture. 


\section{References:}

ADAMIEC G. and AITKEN MJ. (1998). Dose-rate conversion factors update. Ancient TL 16: 37-50

AITKEN, M. J. (1998). An Introduction to Optical Dating: The dating of Quaternary sediments by the use of Photo-Stimulated Luminescence. Oxford Science Publication.

BATEMAN, M.D., FREDERICK, C.D., BOULTER, C. (2007). Detecting Post-depositional sediment disturbance in sandy deposits using optical luminescence. Quaternary Geochronology, in press.

BATEMAN, M.D.2 FREDERICK, C.D., JAISWAL, M.K. AND SINGHVI, A.K. (2003). Investigations into the potential effects of pedoturbation on luminescence dating. Quaternary Science Reviews, 22, 1169-1176.

BATEMAN, M.D. \& CATT, J.A. (1996). An absolute chronology for the raised beach deposits at Sewerby, E. Yorkshire, UK. Journal of Quaternary Science, 11, 389-395.

DULLER, G.A.T. (2004) . Luminescence dating of Quaternary sediments: recent advances. Journal of Quaternary Science, 19, 183-192.

HEIMSATH, A.M., CHAPPELL, J., SPOONER, N.A. AND QUESTIAUX, D.G. (2002). Creeping Soil. Geological Society of America, 30, 111-114.

MARSH RE, PRESTWICH WV, RINK WJ, BRENNAN BJ. (2002). Monte Carlo determinations of the beta dose rate to tooth enamel. Radiation Measurements 35: 609-616

MURRAY, A.S. \& WINTLE, A.G. (2000). Luminescence dating of quartz using an improved single-aliquot regenerative-dose protocol. Radiation Measurements 32, 57-73.

MURRAY AS, WINTLE AG. (2003). The single aliquot regenerative dose protocol: potential for improvements in reliability. Radiation Measurements 37: 377-381.

OLLEY, J.M., PIETSCH T., ROBERTS, R.G. (2004). Optical dating of Holocene sediments from a variety of geomorphic settings using single grains of quartz. Geomorphology 60, 337-358.

PRESCOTT, J.R. \& HUTTON, J.T. (1994). Cosmic ray contributions to dose rates for luminescence and ESR dating: large depths and long-term time variations. Radiation Measurements, 2/3, 497-500. 


\section{Appendix 1}

\section{Grain specific data and plots for Plainview site 41HA1, Texas USA}

Sample specific data including:-

- $\quad$ list of De's derived from individual grains.

- $\quad$ Calculated means based on different statistical approaches

- $\quad$ histogram plot of distribution of De within a sample for Single grain/standard aliquot .

- $\quad$ probability density plot (curve) with ranked De data (black points) and probability mean (uppermost red point).

- Radial plot of data 
Field Code:

Lab Code:

Grain
1
2
3
4
5
6
7
8
9
10
11
12
13
14
15
16
17
18
19
20
21
22
23
24
25
26

26

27

28

29

30

31

32

33

34

35

36

37

38

39

40
OSL \#1

Shfd06115

error

1.64

3.69

1.07

2.12

0.94

1.60

1.97

2.98

2.87

3.79

6.40

0.78

1.81

2.21

1.74

1.27

1.05

1.26

5.00

2.37

2.60

3.39

2.59

1.45

1.89

10.46

3.72

2.38

0.69

0.35

0.14

0.37

1.15

0.20

0.52

0.57

0.00

0.89

0.51

0.49
Site: Plainview

Texas

$\begin{array}{rcc}\text { Grain } & \text { Palaeodose (Gy) } & \text { error } \\ 41 & 23.89 & 1.26 \\ 42 & 3.29 & 2.23 \\ 43 & 21.74 & 1.64 \\ 44 & 18.33 & 1.04 \\ 45 & 16.98 & 1.86 \\ 46 & 13.30 & 1.37 \\ 47 & 19.41 & 3.52 \\ 48 & 23.18 & 2.09 \\ 49 & 32.98 & 9.41 \\ 50 & 17.20 & 1.77 \\ 51 & 19.96 & 2.79 \\ 52 & 23.70 & 3.68 \\ 53 & 22.61 & 5.54 \\ 54 & 22.42 & 2.84 \\ 55 & 21.10 & 1.43 \\ 56 & 16.06 & 2.95 \\ 57 & 24.20 & 1.57 \\ 58 & 20.94 & 5.10 \\ 59 & 18.30 & 4.31 \\ 60 & 24.94 & 1.67 \\ 61 & 29.23 & 1.58 \\ 62 & 20.27 & 2.47 \\ 63 & 23.65 & 2.43 \\ 64 & 15.60 & 3.64 \\ 65 & 25.46 & 3.61 \\ 66 & 27.39 & 2.26\end{array}$


Field Code: Lab Code:
OSL \#1

Shfd06115

\begin{tabular}{|c|c|c|c|c|c|}
\hline & & & & $\begin{array}{l}\text { Zero Grains } \\
\text { Min (Gy) } \\
\operatorname{Max~(Gy)~}\end{array}$ & $\begin{array}{r}5 \% \\
0.00 \\
45.08\end{array}$ \\
\hline Unweighted & & Weighted & & Probability & \\
\hline Mean (Gy) & 20.589 & Mean (Gy) & 20.704 & Mean (Gy) & 20.667 \\
\hline SD & 2.942 & SD & 2.556 & SD & 2.961 \\
\hline SE & 0.371 & SE & 0.415 & SE & 0.480 \\
\hline
\end{tabular}

n

Central age model

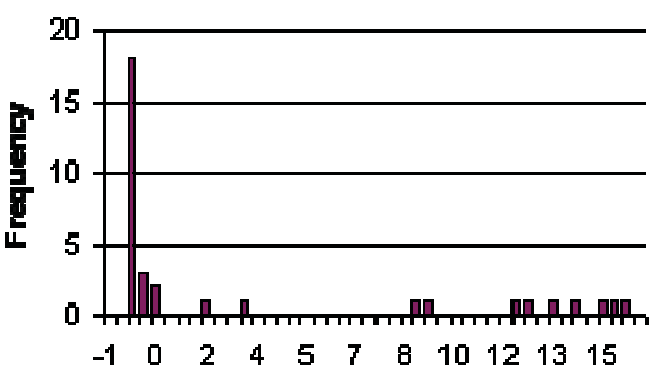

Mean (Gy)

16.65

SE

1.56

Overdispersion

$70.0 \%$

$\mathbf{N}$

66
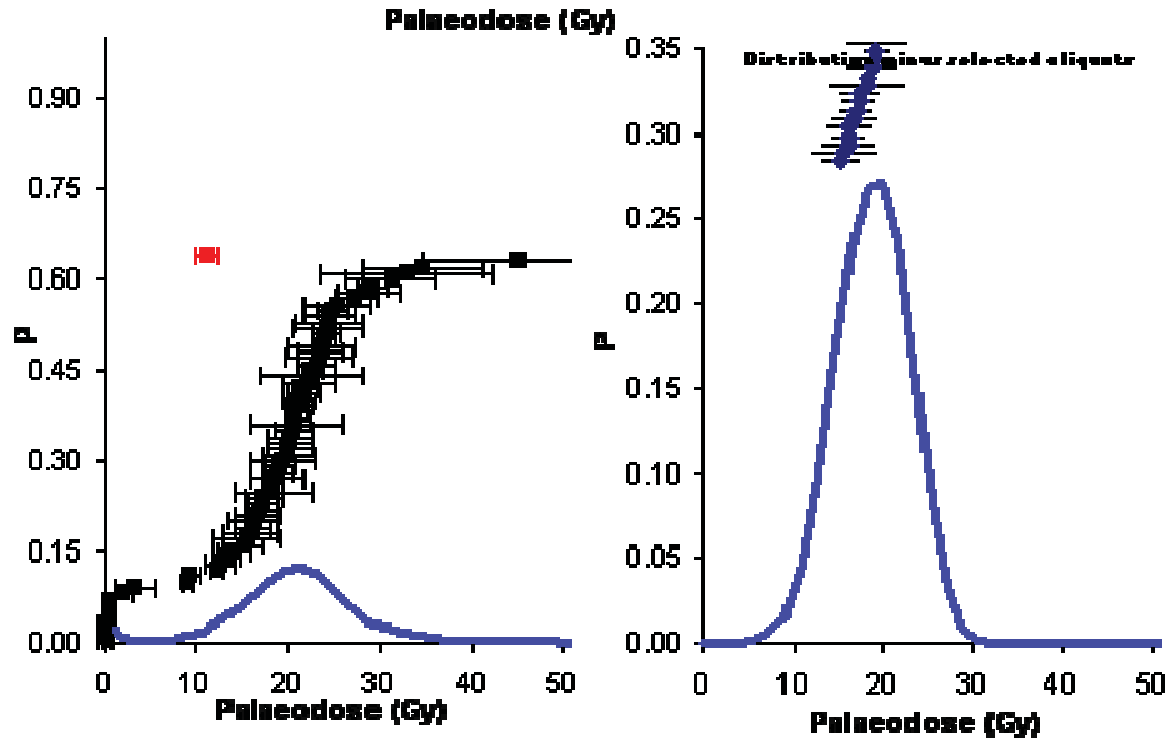
Field Code:

Lab Code:

\section{Grain}

Palaeodose

(Gy)

4.87

7.16

8.42

8.85

8.88

10.07

10.16

11.30

11.51

12.37

12.40

12.83

12.86

12.89

12.95

13.01

13.44

13.90

14.21

14.48

14.57

14.79

15.03

15.16

15.19

15.55

15.55

15.98

15.98

16.23

16.26

16.35

16.72

17.48

17.57

18.03

18.74

19.04

19.10

19.53
\#OSL2

Shfd06116

error

0.81

1.33

0.61

1.04

1.06

1.67

1.13

2.01

1.47

1.42

1.73

1.88

1.39

2.31

1.56

1.73

2.39

2.31

0.66

3.49

1.52

2.26

1.76

1.76

1.30

2.37

3.44

1.58

1.10

1.68

2.80

2.91

2.05

1.65

2.14

2.19

2.57

3.35

2.31

2.58
Site: Plainview

Texas

$\begin{array}{ccc}\text { Grain } & \begin{array}{c}\text { Palaeodose } \\ \text { (Gy) }\end{array} & \text { error } \\ 41 & 19.59 & 2.22 \\ 42 & 19.72 & 2.60 \\ 43 & 19.96 & 5.37 \\ 44 & 20.21 & 2.19 \\ 45 & 20.54 & 2.34 \\ 46 & 21.52 & 2.24 \\ 47 & 21.68 & 2.80 \\ 48 & 23.12 & 3.11 \\ 49 & 23.18 & 1.36 \\ 50 & 24.49 & 2.37 \\ 51 & 25.60 & 3.15 \\ 52 & 26.98 & 5.17 \\ 53 & 30.29 & 1.53 \\ 54 & 34.08 & 5.24 \\ 55 & 35.59 & 4.61 \\ 56 & 36.77 & 2.89\end{array}$


Field Code: Lab Code:

Unweighted

Mean (Gy)

SD

SE

n
OSL \#2

Shfd06116

$\begin{array}{lr}\text { Zero Grains } & 0 \% \\ \text { Min } & 4.87 \\ \text { Max } & 36.77\end{array}$

Probability

Mean (Gy)

15.161

3.559

0.531
SD

3.185

0.475

Central age model

Mean (Gy)

16.10

SE

0.82

Overdispersion

$\mathbf{N}$

56

Palnedore (Gy)
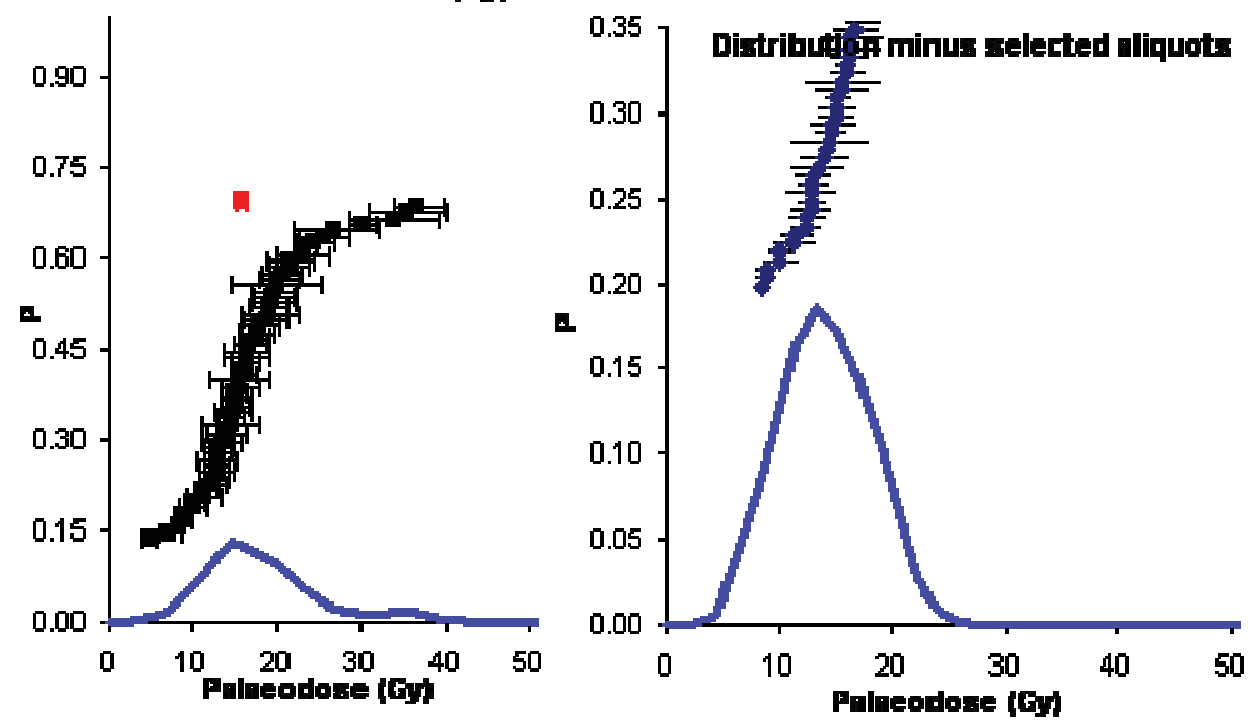



\section{APPENDIX C PLAINVIEW TRENCH DESCRIPTOINS}

Charles D. Frederick, $P h D$ 



\section{Gradall Trench 1}

Geologic Units: Fill

Cultural material: None other than the deposit

Comments: Not described in detail. Trench revealed fill to a depth of 5 feet.

\section{Gradall Trench 2}

Geologic Units: Stratum 5 resting upon stratum 4.

Cultural material: Historic material observed in the top half meter or so.

Comments: Zone 1 is disturbed but it is not clearly fill.

\begin{tabular}{|c|c|c|c|l|}
\hline Zone & Horizon & Depth (cm) & Stratum & Description \\
\hline 1 & Ap & $0-30$ & 5 & $\begin{array}{l}\text { Dark brown (7.5YR 3/2) loam, friable, moderate fine to very fine subangular } \\
\text { blocky structure, diffuse smooth boundary, very strongly effervescent, an } \\
\text { electrical fuse was found at 20 cm, and pipe within a setting trench was } \\
\text { present at 55 cm; zone appears to be disturbed. }\end{array}$ \\
\hline 2 & $\mathrm{C}$ & $30-70$ & 5 & $\begin{array}{l}\text { Dark brown (7.5YR 3/2) loam, very friable, weak fine subangular blocky } \\
\text { structure, clear smooth boundary, very strongly effervescent. }\end{array}$ \\
\hline 3 & $\mathrm{C}$ & $70-82$ & 5 & $\begin{array}{l}\text { Dark grayish brown to brown (10YR 4/2 to 5/3) loam, very friable, massive, } \\
\text { abrupt irregular boundary, very strongly effervescent, contains a number of } \\
\text { isolated fragments of brown (10YR 5/3) sand that may have once been a } \\
\text { continuous bed but are now broken up by bioturbation. }\end{array}$ \\
\hline 4 & $2 \mathrm{Ab}$ & $82-109$ & $4 \mathrm{~m}$ & $\begin{array}{l}\text { Black (10YR 2/1) silty clay loam to loam, fining upwards, friable, strong } \\
\text { medium subangular blocky structure, gradual smooth boundary, strongly } \\
\text { effervescent, few (1\%) calcium carbonate filaments. }\end{array}$ \\
\hline 5 & $2 \mathrm{AB}$ & $109-145$ & $4 \mathrm{~m}$ & $\begin{array}{l}\text { Very dark grayish brown (10YR 3/2) loam to silty clay loam, very friable, } \\
\text { moderate medium subangular blocky structure, gradual smooth boundary, } \\
\text { few calcium carbonate filaments, moderately effervescent, few very small } \\
\text { bone fragments were observed around 1.4 m. }\end{array}$ \\
\hline 6 & $2 \mathrm{Bw}$ & $145-155$ & $4 \mathrm{~m}$ & $\begin{array}{l}\text { Dark brown (10YR 3/3) loam, very friable, weak medium subangular } \\
\text { blocky structure, few (<1\%) calcium carbonate filaments, moderately } \\
\text { effervescent. }\end{array}$ \\
\hline
\end{tabular}

\section{Gradall Trench 3}

Geologic Units: Fill resting upon stratum 4/5m, which in turn rests upon stratum 3.

Cultural material: a variety of cultural items were observed within zone 1, the anthrogenic fill, but nothing below that.

Comments:

\begin{tabular}{|c|c|c|c|l|}
\hline Zone & Horizon & Depth $\mathbf{( c m )}$ & Stratum & Description \\
\hline 1 & C & $0-80$ & Fill & $\begin{array}{l}\text { Very dark gray to very dark grayish brown (10YR 3/1 to 3/2) loam to silty } \\
\text { clay loam, friable, massive, abrupt smooth boundary, strongly effervescent, } \\
\text { contains concrete, coal and metal (part of a wire fence staple). }\end{array}$ \\
\hline 2 & $2 \mathrm{Bw}$ & $80-110$ & $4 / 5 \mathrm{~m}$ & $\begin{array}{l}\text { Very dark grayish brown to dark grayish brown (10YR 3/2 to 10YR } \\
4 / 2) \text { loam, very friable, massive, clear smooth boundary, very strongly } \\
\text { effervescent, few (1\%) calcium carbonate filaments, trace of gravel near } \\
\text { the base of this zone. }\end{array}$ \\
\hline 3 & $2 \mathrm{BA}$ & $110-130$ & $4 / 5 \mathrm{~m}$ & $\begin{array}{l}\text { Very dark grayish brown (10YR 3/2) loam, weak medium subangular blocky } \\
\text { structure, abrupt smooth boundary, very strongly effervescent, few (1\%) } \\
\text { calcium carbonate filaments. }\end{array}$ \\
\hline
\end{tabular}




\begin{tabular}{|c|c|c|c|l|}
\hline 4 & $3 \mathrm{Ab}$ & $130-139$ & 3 & $\begin{array}{l}\text { Very dark gray (10YR 3/1) to dark gray (10YR 4/1) loam to silty clay loam, } \\
\text { friable, moderate fine subangular blocky structure, abrupt wavy boundary, } \\
\text { very strongly effervescent, numerous channels filled with zone } 5 \text { sediment } \\
\text { (worm passage features). }\end{array}$ \\
\hline 5 & $3 \mathrm{C}$ & $139-155$ & 3 & $\begin{array}{l}\text { White }(\mathrm{N} \text { 8/0 to 10YR 8/1) loam, friable, weak medium subangular blocky } \\
\text { structure, violently effervescent, abundant diffuse calcium carbonate, } \\
\text { marl. }\end{array}$ \\
\hline
\end{tabular}

\section{Gradall Trench 4}

Geologic Units: Fill $(0-20 \mathrm{~cm})$, resting upon Stratum 5 Group C (5Gc)channel deposits $(20-125 \mathrm{~cm})$, which in turn rest upon stratum 5 Group B $(5 \mathrm{~Gb})$ channel deposits $(125-220 \mathrm{~cm})$, which unconformably rest upon stratum 1.

Cultural material: None observed.

Comments: Three radiocarbon ages were obtained from this trench, and the results are noted in each zone description, below.

\begin{tabular}{|c|c|c|c|c|}
\hline Zone & Horizon & Depth $(\mathrm{cm})$ & Stratum & Description \\
\hline 1 & C & $0-20$ & Fill & $\begin{array}{l}\text { Brown (7.5YR 4/3) loam, friable, weak coarse subangular blocky structure, } \\
\text { abrupt smooth boundary, moderately effervescent, introduced fill. }\end{array}$ \\
\hline 2 & $2 A b$ & $20-40$ & $5 \mathrm{Gc}$ & $\begin{array}{l}\text { Very dark gray (10YR 3/1) loam, friable, moderate to strong medium to } \\
\text { fine subangular blocky structure, gradual smooth boundary, strongly } \\
\text { effervescent. }\end{array}$ \\
\hline $3 a$ & $2 \mathrm{C}$ & $40-109$ & $5 \mathrm{Gc}$ & $\begin{array}{l}\text { Brown (7.5YR 4/3) loamy sand, very friable, massive, strongly effervescent, } \\
\text { interbedded with 3b; a bone fragment collected from zone 3a at a depth } \\
\text { of approximately @ } 85 \mathrm{~cm} \text { yielded an age of } 350 \pm 40 \text { years BP (Beta- } \\
\text { 224046). }\end{array}$ \\
\hline $3 b$ & $2 \mathrm{C}$ & $40-109$ & $5 \mathrm{Gc}$ & $\begin{array}{l}\text { Pale brown (10YR 6/3) sand, loose, single grain, abrupt smooth boundary, } \\
\text { strongly effervescent, zone comprises at least } 5 \text { distinct thin beds }(74-75 \\
\mathrm{cm}, 80-81 \mathrm{~cm}, 83-86 \mathrm{~cm}, 94-98 \mathrm{~cm} \text {, and } 104-105 \mathrm{~cm}) \text { that are interbedded } \\
\text { with zone 3a. }\end{array}$ \\
\hline 4 & $2 \mathrm{C}$ & $109-120$ & $5 \mathrm{Gc}$ & $\begin{array}{l}\text { Brown (7.5YR 4/3) slightly gravelly sand to loamy sand, very friable, } \\
\text { massive, abrupt smooth boundary, strongly effervescent, normally graded, } \\
\text { appears slightly disturbed, } 1-3 \% \text { coarse fragments. }\end{array}$ \\
\hline 5 & $2 \mathrm{C}$ & $120-125$ & $5 \mathrm{Gc}$ & $\begin{array}{l}\text { Light yellowish brown (10YR 6/4) sand, loose, single grain, abrupt } \\
\text { discontinuous boundary, strongly effervescent, this is a discontinuous flood } \\
\text { drape, very disturbed by bioturbation. }\end{array}$ \\
\hline 6 & $3 A b$ & $125-145$ & $5 \mathrm{~Gb}$ & $\begin{array}{l}\text { Brown (7.5YR } 4 / 3) \text { loam, friable to very friable, weak fine to medium } \\
\text { subangular blocky structure, abrupt smooth boundary, strongly effervescent, } \\
\text { few }(1-2 \%) \text { calcium carbonate filaments, contains at lest three very thin }(<1 \\
\mathrm{cm}) \text { sandy flood drapes in bottom half of the zone,; a bulk soil sample } \\
\text { collected from the top } 3 \mathrm{~cm} \text { of this soil }(125-128 \mathrm{~cm}) \text { yielded a radiocarbon } \\
\text { age of } 1,800 \pm 40 \text { years BP (Beta-224047). }\end{array}$ \\
\hline 7 & $3 C$ & $145-150$ & $5 \mathrm{~Gb}$ & $\begin{array}{l}\text { Yellowish brown (10YR 5/4) slightly gravelly coarse sand, very friable, } \\
\text { single grain, abrupt wavy boundary, strongly effervescent, } 15-25 \% \text { coarse } \\
\text { fragments. }\end{array}$ \\
\hline 8 & $3 C$ & $150-156$ & $5 \mathrm{~Gb}$ & $\begin{array}{l}\text { Pale brown (109YR 6/3) loamy sand, friable, single grain, abrupt } \\
\text { discontinuous boundary, strongly effervescent. }\end{array}$ \\
\hline 9 & $3 C$ & $156-160$ & $5 \mathrm{~Gb}$ & $\begin{array}{l}\text { Pale brown (109YR 6/3) sand, loose, single grain, abrupt discontinuous } \\
\text { boundary, strongly effervescent. }\end{array}$ \\
\hline 10 & $3 C$ & $160-173$ & $5 \mathrm{~Gb}$ & $\begin{array}{l}\text { Brown (7.5YR 4/3) loamy sand, very friable, massive, abrupt wavy } \\
\text { boundary, strongly effervescent, few }(1-3 \%) \text { coarse fragments. }\end{array}$ \\
\hline
\end{tabular}




\begin{tabular}{|c|c|c|c|c|}
\hline 11 & $3 C$ & $173-183$ & $5 \mathrm{~Gb}$ & $\begin{array}{l}\text { Brown to pale brown (10YR } 4 / 3 \text { to } 10 \mathrm{YR} 6 / 3) \text { sand to loamy sand, loose to } \\
\text { very friable, single grain, abrupt smooth boundary, normally graded, with } \\
2-3 \mathrm{~cm} \text { of coarse sand at base of zone, horizontally laminated. }\end{array}$ \\
\hline 12 & $3 C$ & $183-190$ & $5 \mathrm{~Gb}$ & $\begin{array}{l}\text { Brown (10YR } 4 / 3) \text { sandy gravel to sandy loam, friable to loose, single } \\
\text { grain, abrupt smooth to wavy boundary, strongly effervescent, graded bed, } \\
2 \mathrm{~cm} \text { of gravel at base ( } \sim 40 \% \text { coarse fragments), with } 2-3 \mathrm{~mm} \text { mun drape } \\
\text { capping the zone. }\end{array}$ \\
\hline 13 & $3 C$ & 190-192 & $5 \mathrm{~Gb}$ & $\begin{array}{l}\text { Brown (10YR } 5 / 3) \text { loamy sand, very friable, massive, abrupt smooth } \\
\text { boundary, very strongly effervescent, }<1 \% \text { coarse fragments. }\end{array}$ \\
\hline 14 & $3 C$ & $192-200$ & $5 \mathrm{~Gb}$ & $\begin{array}{l}\text { Very pale brown (10YR } 7 / 3) \text { slightly gravelly sand to sand, loose, single } \\
\text { grain, abrupt smooth boundary, normally graded bed with } 1 \mathrm{~cm} \text { og gravel } \\
\text { scattered across the lower boundary, } 15 \% \text { coarse fragments. }\end{array}$ \\
\hline 15 & $3 C$ & $200-210$ & $5 \mathrm{~Gb}$ & $\begin{array}{l}\text { Dark grayish brown (10YR 4/2) loamy sand, very friable to friable, massive, } \\
\text { abrupt smooth boundary, strongly effervescent, laminated; a sample of this } \\
\text { mud collected from the top of the zone at } 200-205 \mathrm{~cm} \text { was radiocarbon } \\
\text { dated and yielded an age } 2920 \pm 40 \text { years BP (Beta-224048). }\end{array}$ \\
\hline 16 & $3 C$ & $210-217$ & $5 \mathrm{~Gb}$ & $\begin{array}{l}\text { Pale brown (10YR 6/3) sand, loose, single grain, abrupt wavy boundary, } \\
\text { strongly effervescent. }\end{array}$ \\
\hline 17 & $3 C$ & $217-220$ & $5 \mathrm{~Gb}$ & $\begin{array}{l}\text { Brown (10YR 4/3) sand to slightly gravelly sand, very friable, single grain, } \\
\text { abrupt wavy boundary, laminated in a fashion similar to flaser bedding. }\end{array}$ \\
\hline 18 & $3 C$ & $220-230$ & 1 & $\begin{array}{l}\text { White (10YR } 8 / 1) \text { sand to slightly gravelly sand, loose, single grain weakly } \\
\text { effervescent, no obvious bedding, } 1-3 \% \text { coarse fragments. }\end{array}$ \\
\hline 19 & $4 C$ & $230-240$ & 1 & $\begin{array}{l}\text { White (10YR } 8 / 1) \text { sand to slightly gravelly sand, loose, single grain weakly } \\
\text { effervescent, low angle foresets, normally graded bed. }\end{array}$ \\
\hline
\end{tabular}

\section{Gradall Trench 5}

Geologic Units: Stratum 5m $(0-130 \mathrm{~cm})$ over stratum 4m $(130-220 \mathrm{~cm})$

Cultural material: None observed.

Comments:

\begin{tabular}{|c|c|c|c|l|}
\hline Zone & Horizon & Depth (cm) & Stratum & Description \\
\hline 1 & Ap & $0-35$ & 5 & $\begin{array}{l}\text { Very dark grayish brown (10YR 3/2) loam, very friable, weak to moderate } \\
\text { medium subangular blocky structure, clear smooth boundary, strongly } \\
\text { effervescent, numerous krotovinas. }\end{array}$ \\
\hline 2 & Bw & $35-83$ & 5 & $\begin{array}{l}\text { Brown (7.5YR 4/3) loam to silt loam, friable, weak coarse subangular blocky } \\
\text { structure, abrupt discontinuous boundary, strongly effervescent. }\end{array}$ \\
\hline $3 a$ & C & $83-106$ & 5 & $\begin{array}{l}\text { Brown (7.5YR 5/4) sand, very friable, moderate fine subangular blocky } \\
\text { structure, abrupt discontinuous boundary, strongly effervescent, interbedded } \\
\text { with zone 3b, at least 4 distinct thin beds. }\end{array}$ \\
\hline $3 b$ & $\mathrm{C}$ & $83-106$ & 5 & $\begin{array}{l}\text { Brown (7.5YR 4/3) silt loam, very friable, strong fine subangular blocky } \\
\text { structure, abrupt discontinuous boundary, strongly effervescent, interbedded } \\
\text { with zone 3a, common discontinuous thin coats of calcium carbonate on } \\
\text { ped faces, common (5\%) calcium carbonate filaments. }\end{array}$ \\
\hline 4 & $\mathrm{C}$ & $106-130$ & 5 & $\begin{array}{l}\text { Dark brown (7.5YR 3/2) silt loam, friable, moderate to strong medium to } \\
\text { fine angular blocky structure, abrupt discontinuous boundary, strongly } \\
\text { effervescent, many (20-40\%) thin discontinuous carbonate coats on ped } \\
\text { faces, common (5-10\%) calcium carbonate filaments, hints of bedding. }\end{array}$ \\
\hline
\end{tabular}




\begin{tabular}{|c|c|c|c|l|}
\hline 5 & 2 AC & $130-132$ & 4 & $\begin{array}{l}\text { Dark brown (7.5YR 3/2) clay, firm to friable, strong medium to fine angular } \\
\text { blocky structure, abrupt discontinuous boundary, strongly effervescent, } \\
\text { clay drape. }\end{array}$ \\
\hline 6 & 2 Abk & $132-145$ & 4 & $\begin{array}{l}\text { Dark brown (7.5YR 3/2 to 3/3) silty clay to clay, firm, strong medium } \\
\text { angular blocky structure parting to strong medium crumb structure, abrupt } \\
\text { smooth boundary, violently effervescent, few (1-2\%) fine (0.5-0.7 mm) } \\
\text { calcium carbonate nodules, common (5\%) calcium carbonate filaments, } \\
\text { few pressure faces, many (20-50\%) thin coats of calcium carbonate on } \\
\text { ped faces. }\end{array}$ \\
\hline 7 & 2 AB & $145-153$ & 4 & $\begin{array}{l}\text { Brown (7.5YR 4.5/3) loam, hard, moderate to strong fine angular blocky } \\
\text { structure, abrupt smooth boundary, slightly effervescent, common (5-7\%) } \\
\text { calcium carbonate filaments, few to common pressure faces, }\end{array}$ \\
\hline 8 & 3 Abk & $153-175$ & 4 & $\begin{array}{l}\text { Very dark gray (7.5YR 3/1) sandy clay, hard, strong fine to medium angular } \\
\text { blocky structure, diffuse smooth boundary, slightly effervescent, many (10- } \\
25 \% \text { calcium carbonate filaments, few coarse (1 cm) sharp edged calcium } \\
\text { carbonate nodules, possibly a Bt horizon. }\end{array}$ \\
\hline 9 & 3 Btk2 & $175-220$ & 4 & $\begin{array}{l}\text { Brown (7.5YR 4/3) clay, hard to extremely hard, strong coarse angular } \\
\text { blocky structure, slightly effervescent, common (10\%) calcium carbonate } \\
\text { filaments, few (<1\%) 1-2 cm hard calcium carbonate nodules. }\end{array}$ \\
\hline
\end{tabular}

\section{Gradall Trench 6}

Geologic Units: stratum 4/5m $(0-114 \mathrm{~cm})$, resting upon stratum $3(114-190 \mathrm{~cm})$, resting upon stratum $1(190-270 \mathrm{~cm})$.

Cultural material: None observed.

Comments:

\begin{tabular}{|c|c|c|c|l|}
\hline Zone & Horizon & Depth (cm) & Stratum & Description \\
\hline 1 & A & $0-22$ & $5-$ Apr & $\begin{array}{l}\text { Very dark gray (7.5YR 3/1) clay to clay loam, firm, strong medium angular } \\
\text { blocky structure parting to strong medium subangular blocky structure, } \\
\text { gradual smooth boundary, slightly effervescent, few pressure faces. }\end{array}$ \\
\hline 2 & ABt & $22-53$ & $5-A p r$ & $\begin{array}{l}\text { Brown (7.5YR 4/3) clay loam, firm, strong medium angular blocky structure, } \\
\text { gradual smooth boundary, strongly effervescent, few cracks filled with zone } \\
1 \text { material (camber cracks from edge slumping toward the draw). }\end{array}$ \\
\hline 3 & Bt & $53-97$ & $5-A p r$ & $\begin{array}{l}\text { Brown (7.5YR 4/3) loam, friable, moderate to strong medium prismatic } \\
\text { structure parting to moderate medium subangular blocky structure, strongly } \\
\text { effervescent, common (5-7\%) calcium carbonate filaments. }\end{array}$ \\
\hline 4 & BA & $97-114$ & $5-A p r$ & $\begin{array}{l}\text { Light brownish gray (2.5Y 6/2) sandy loam, very friable, weak to moderate } \\
\text { medium subangular blocky structure, abrupt smooth boundary, strongly to } \\
\text { violently effervescent, numerous krotovina. }\end{array}$ \\
\hline 5 & 2Abk & $114-139$ & 3 & $\begin{array}{l}\text { Grayish brown (2.5Y 5/2) silt loam, friable, moderate to strong medium to } \\
\text { fine subangular blocky structure, abrupt discontinuous boundary, violently } \\
\text { effervescent, common 1 cm wide by 2 to 3 cm long vertically oriented soft } \\
\text { masses of calcium carbonate, some of which have hard nodules as well, } \\
\text { few krotovina, probably the Yellowhouse soil. }\end{array}$ \\
\hline 6 & 2C & $139-158$ & 3 & $\begin{array}{l}\text { Light gray (2.5Y 7/2) loamy sand, friable, moderate medium to fine } \\
\text { subangular blocky structure, abrupt smooth boundary, violently effervescent, } \\
\text { abundant diffuse calcium carbonate. }\end{array}$ \\
\hline 7 & 2C & $158-171$ & 3 & $\begin{array}{l}\text { Light brownish gray (2.5Y 6/2) sandy loam, friable to firm, moderate fine } \\
\text { subangular blocky structure, abrupt smooth boundary, violently effervescent, } \\
\text { abundant diffuse calcium carbonate. }\end{array}$ \\
\hline 2C & $171-181$ & 3 & $\begin{array}{l}\text { dark grayish brown (2.5Y 4/2) loamy sand, very friable, weak fine subangular } \\
\text { blocky structure, abrupt irregular boundary, strongly effervescent. }\end{array}$ \\
\hline
\end{tabular}




\begin{tabular}{|c|c|c|c|l|}
\hline 9 & 2C & $181-183$ & 3 & $\begin{array}{l}\text { Very pale brown (10YR 8/2) very fine sand, loose, single grain, abrupt } \\
\text { irregular boundary, very slightly effervescent. }\end{array}$ \\
\hline 10 & 2C & $183-190$ & 3 & $\begin{array}{l}\text { Grayish brown (2.5Y 5/2) sandy loam, friable, weak to moderate } \\
\text { medium subangular blocky structure, abrupt irregular boundary, violently } \\
\text { effervescent, few dark grayish brown (2.5YR 4/2) clay coats on ped faces. }\end{array}$ \\
\hline 11 & 3C & $190-201$ & 1 & $\begin{array}{l}\text { Light brownish gray (10YR 6/2) fine sand, very friable, single grain, abrupt } \\
\text { smooth boundary, very slightly effervescent, traces of bedding, somewhat } \\
\text { disturbed. }\end{array}$ \\
\hline 12 & 3C & $201-220$ & 1 & $\begin{array}{l}\text { Very pale brown (10YR 8/2) gravelly sand, loose, single grain, abrupt } \\
\text { smooth boundary, strongly effervescent, 40-60\% coarse fragments. }\end{array}$ \\
\hline 13 & 3C & $220-265$ & 1 & $\begin{array}{l}\text { Very pale brown (10YR 7/4 to 8/2) medium to fine sand, loose, single grain, } \\
\text { abrupt smooth boundary, slightly effervescent, cross-laminated, some } \\
\text { trough cross-bedding. }\end{array}$ \\
\hline 14 & 3C & $265-270$ & 1 & $\begin{array}{l}\text { Very pale brown (10YR 7/3) slightly gravelly sand, loose, single grain, } \\
\text { strongly effervescent, 10-25\% coarse fragments, no clear bedding. }\end{array}$ \\
\hline
\end{tabular}

\section{Gradall Trench 7}

Geologic Units: Recent fill $(0-30 \mathrm{~cm})$ over stratum 4/5m $(30-140 \mathrm{~cm})$.

Cultural material: None observed.

Comments:

\begin{tabular}{|c|c|c|c|l|}
\hline Zone & Horizon & Depth (cm) & Stratum & Description \\
\hline 1 & C & $0-12$ & Fill & Not described. \\
\hline 2 & C & $24-\mathrm{Dec}$ & Fill & Not described. \\
\hline 3 & C & $24-29$ & Fill & Not described. \\
\hline 4 & 2 Ab1 & $29-65$ & 5-Apr & $\begin{array}{l}\text { Dark brown (7.5YR 3/3) silty clay loam, very friable, weak coarse subangular } \\
\text { blocky structure, abrupt smooth boundary, strongly effervescent, few cracks } \\
\text { filled with sand. }\end{array}$ \\
\hline 5 & 2 Ab2 & $65-100$ & $5-A p r$ & $\begin{array}{l}\text { Black (10YR 2/1) silty clay loam, firm, strong fine angular blocky structure, } \\
\text { clear smooth boundary, slightly effervescent, few (<1\%) calcium carbonate } \\
\text { filaments. }\end{array}$ \\
\hline 6 & $2 B k 1$ & $100-125$ & 5-Apr & $\begin{array}{l}\text { Dark brown (7.5YR 3/3) loam, very firm, moderate medium prismatic } \\
\text { structure parting to strong medium angular blocky structure, clear smooth } \\
\text { boundary, slightly to strongly effervescent, common (7-10\%) calcium } \\
\text { carbonate filaments, common distinct to prominent coats of calcium } \\
\text { carbonate on ped faces. }\end{array}$ \\
\hline 7 & $2 B k 2$ & $125-140$ & 5-Apr & $\begin{array}{l}\text { Brown (7.5YR 4/4) loamy sand, friable, moderate very coarse to coarse } \\
\text { prismatic structure, strongly effervescent, few (1-3\%) calcium carbonate } \\
\text { filaments, few to common faint coats of calcium carbonate on ped faces. }\end{array}$ \\
\hline
\end{tabular}

\section{Gradall Trench 8}

Geologic Units: unknown

Cultural material: No prehistoric material observed.

Comments: Not described. Only a very small fragment of in situ sediment was revealed by this trench. Most was land fill.

\section{Gradall Trench 9}

Geologic Units: stratum $5(0-105 \mathrm{~cm})$ on top of stratum $4(105-150 \mathrm{~cm})$.

Cultural material: None observed.

Comments: 


\begin{tabular}{|c|c|c|c|l|}
\hline Zone & Horizon & Depth (cm) & Stratum & Description \\
\hline 1 & Ap & $0-22$ & 5 & $\begin{array}{l}\text { Very dark grayish brown (10YR 3/2) loam, very friable, weak medium to } \\
\text { coarse subangular blocky structure, abrupt smooth boundary, very slightly } \\
\text { effervescent. }\end{array}$ \\
\hline 2 & A & $22-67$ & 5 & $\begin{array}{l}\text { Dark brown (7.5YR 3/2) loam to silty clay loam, very friable, moderate } \\
\text { medium to fine subangular blocky structure, gradual smooth boundary, } \\
\text { top } 20 \text { cm very slightly effervescent, lower part strongly effervescent, few } \\
\text { pressure faces. }\end{array}$ \\
\hline 3 & Bw & $67-105$ & 5 & $\begin{array}{l}\text { Brown (7.5YR 4/4) silty clay loam, friable to very friable, moderate to } \\
\text { strong fine subangular blocky structure, abrupt smooth boundary, strongly } \\
\text { effervescent. }\end{array}$ \\
\hline 4 & $2 \mathrm{Ab}$ & $105-121$ & 4 & $\begin{array}{l}\text { Dark brown (7.5YR 3/3) slightly gravelly silty clay loam, friable, weak to } \\
\text { moderate coarse subangular blocky structure, clear smooth boundary, } \\
\text { strongly effervescent, common (5-7) calcium carbonate filaments, few } \\
\text { thin very dark brown (7.5YR 2.5/2) clay coats on ped faces, 1-3\% coarse } \\
\text { fragments. }\end{array}$ \\
\hline 5 & $2 \mathrm{C}$ & $121-150$ & 4 & $\begin{array}{l}\text { Brown (7.5YR 4/3) slightly gravelly loam, very friable, weak coarse } \\
\text { subangular blocky structure, strongly effervescent, few (1-3\%) coarse } \\
\text { fragments, matrix supported. }\end{array}$ \\
\hline
\end{tabular}

\section{Gradall Trench 10}

Geologic Units: Stratum 5, group A channel/floodplain complex, resting upon stratum 4.

Cultural material: None observed.

Comments: No depths are listed as there was significant lateral variation within the trench. Refer to the long wall drawing for the relative stratigraphic position of the strata described below. Two bison skulls were observed resting upon the zone 13-14 interface.

\begin{tabular}{|c|c|c|c|l|}
\hline Zone & Horizon & Depth (cm) & Stratum & Description \\
\hline 1 & & - & 5 & $\begin{array}{l}\text { Dark grayish brown (10YR 4/2) loam, very friable, weak coarse subangular } \\
\text { blocky structure, abrupt smooth boundary, strongly effervescent. }\end{array}$ \\
\hline 2 & -- & 5 & $\begin{array}{l}\text { Very dark grayish brown (10YR 3/2) loam, very friable, weak to moderate } \\
\text { medium subangular blocky structure, abrupt smooth boundary, strongly } \\
\text { effervescent, few (0-3) calcium carbonate filaments. }\end{array}$ \\
\hline 3 & -- & 5 & $\begin{array}{l}\text { Pale brown-light yellowish brown (10YR 6/3.5) sand, loose, single grain, } \\
\text { abrupt smooth boundary, strongly effervescent, few (1\%) calcium carbonate } \\
\text { filaments in finer sands. }\end{array}$ \\
\hline 4 & -- & 4 & $\begin{array}{l}\text { Black (10YR 2/1) silty clay loam, firm to friable, strong fine prismatic } \\
\text { structure parting to strong medium angular blocky structure, gradual } \\
\text { smooth boundary, slightly effervescent, common (5-7\%) calcium carbonate } \\
\text { filaments, few (<1\%) 0.5 cm calcium carbonate nodules. }\end{array}$ \\
\hline 5 & -- & 4 & $\begin{array}{l}\text { Brown (7.5YR 4/3) silty clay loam, firm, moderate coarse prismatic structure } \\
\text { parting to strong medium to coarse angular blocky structure, gradual } \\
\text { smooth boundary, few to common (3-5\%) calcium carbonate filaments, few } \\
(1 \%) \text { medium to coarse (<0.7 cm) calcium carbonate nodules, common } \\
(10-25 \%) \text { discontinuous calcium carbonate coats on ped faces. }\end{array}$ \\
\hline 6 & -- & 4 & $\begin{array}{l}\text { Brown (7.5YR 4/4) loam to sandy clay loam, friable, moderate medium } \\
\text { subangular blocky structure, violently effervescent. }\end{array}$ \\
\hline 7 & & 5 & $\begin{array}{l}\text { Black (10YR 2/1) clay, firm, strong medium to coarse angular blocky } \\
\text { structure, clear smooth boundary, strongly effervescent. }\end{array}$ \\
\hline
\end{tabular}




\begin{tabular}{|c|c|c|l|}
\hline 8 & -- & 5 & $\begin{array}{l}\text { Very dark grayish brown (10YR 3/2) silty clay loam, friable, strong medium } \\
\text { to coarse angular blocky structure, abrupt discontinuous boundary, strongly } \\
\text { effervescent, many burrows/krotovina. }\end{array}$ \\
\hline 9 & -- & 5 & $\begin{array}{l}\text { Brown (10YR 5/4)very fine sand, very friable, weak fine subangular blocky } \\
\text { structure, abrupt discontinuous boundary, strongly effervescent, laminated, } \\
\text { discontinuous bed disturbed by pedoturbation. }\end{array}$ \\
\hline 10 & -- & 5 & $\begin{array}{l}\text { Very dark gray (10YR 3/1) clay, firm, strong fine angular blocky structure, } \\
\text { abrupt discontinuous boundary, violently effervescent, clay drape that } \\
\text { thickens toward the channel axis, interrupted by bioturbation. }\end{array}$ \\
\hline 11 & -- & 5 & $\begin{array}{l}\text { Brown (10YR 5/4) sand, loose, single grain, abrupt discontinuous boundary, } \\
\text { slightly effervescent, no obvious bedding, 10-20\% 0.5-1 cm diameter mud } \\
\text { rip up clasts. }\end{array}$ \\
\hline 12 & -- & 5 & $\begin{array}{l}\text { Very dark gray (10YR 3/1) clay, friable, strong very fine to fine angular blocky } \\
\text { structure parting to strong medium granular structure, abrupt discontinuous } \\
\text { boundary, strongly effervescent, mud drape. }\end{array}$ \\
\hline 13 & -- & 5 & $\begin{array}{l}\text { Light yellowish brown (10YR 6/4) medium to coarse sand, loose, single } \\
\text { grain, abrupt wavy to irregular boundary, strongly effervescent, prominently } \\
\text { cross-laminated, some trough cross-beds, } 10 \% \text { coarse fragments, two } \\
\text { bison skulls were collected from the base of this zone, one of which was } \\
\text { radiocarbon dated and yielded an age of 2740 } 440 \text { years BP, (Beta-224049), } \\
\text { top of underlying zone looks trampled. }\end{array}$ \\
\hline 14 & 5 & $\begin{array}{l}\text { Black (10YR 2/1) clay, friable, strong very coarse granular structure, abrupt } \\
\text { smooth boundary, slightly effervescent, few (1-5\%) calcium carbonate } \\
\text { filaments, few distinct fine light olive brown (2.5Y 5/6) mottles around } \\
\text { pores, thick mud drape, with a trampled upper surface. }\end{array}$ \\
\hline & -- & $\begin{array}{l}\text { Very dark brown (7.5YR 2.5/2) sandy clay, friable, moderate coarse } \\
\text { subangular blocky structure, abrupt smooth boundary, slightly effervescent, } \\
\text { wash from side of draw. }\end{array}$ \\
\hline
\end{tabular}

\section{Gradall Trench 11}

Geologic Units: Stratum 5 (group C) resting on stratum 4 at east end; stratum 5 group A channel resting upon Stratum 4(?) at west end, with stratum 4 resting upon stratum 1, and in tur resting upon the Ogallala Formation.

Cultural material: Historic age metal and glass were observed within zone 5.

Comments: No depths are listed as there was significant lateral variation within the trench. Refer to the long wall drawing for the relative stratigraphic position of the strata described below.

\begin{tabular}{|c|c|c|c|l|}
\hline Zone & Horizon & Depth (cm) & Stratum & Description \\
\hline 1 & Ap & -- & 5 & $\begin{array}{l}\text { Black (10YR 2/1) silty clay to clay, friable, moderate to strong fine granular } \\
\text { structure, abrupt smooth boundary, strongly effervescent. }\end{array}$ \\
\hline 2 & AC & -- & 5 & $\begin{array}{l}\text { Dark yellowish brown (10YR 4/4) loamy sand and very dark grayish brown } \\
(10 Y R \text { 3/2) loam, very friable, weak too moderate medium subangular } \\
\text { blocky structure, abrupt smooth boundary, strongly effervescent. }\end{array}$ \\
\hline 3 & C & -- & 5 & $\begin{array}{l}\text { Black (10YR 2/1) to very dark gray (10YR 3/1) silty clay loam to loam, } \\
\text { friable, moderate medium to fine subangular blocky structure, abrupt } \\
\text { smooth boundary, strongly effervescent, few discontinuous } ~ \\
\text { brown } \text { cm thick } \\
\text { zone. }\end{array}$ \\
\hline 4 & C & -- & 5 & $\begin{array}{l}\text { Very dark gray (10YR sand beds at widely scattered intervals within this } \\
\text { subangularblocky structure, abrupt smooth boundary, violently effervescent, } \\
\text { few charcoal fragments. }\end{array}$ \\
\hline
\end{tabular}




\begin{tabular}{|c|c|c|c|c|}
\hline 5 & $C$ & -- & 5 & $\begin{array}{l}\text { Black (10YR 2/1) clay, firm, strong medium to fine subangular blocky } \\
\text { structure parting to strong medium granular structure, abrupt smooth } \\
\text { boundary, violently effervescent, merges with zone } 7 \text { to the west; contains } \\
\text { numerous pieces of metal and glass, and occasional bits of charcoal. }\end{array}$ \\
\hline 6 & $C$ & -- & 5 & $\begin{array}{l}\text { Dark brown }(7.5 Y R \text { 3/2)loam to silty clay loam, very friable, strong very } \\
\text { fine to fine subangular blocky structure, abrupt smooth boundary, probably } \\
\text { was once a single light brown }(7.5 \mathrm{YR} 6 / 4) \text { sand bed but has been seriously } \\
\text { impacted by roots and worms. }\end{array}$ \\
\hline 7 & C & -- & 5 & $\begin{array}{l}\text { Black (10YR 2/1) silty clay loam, very friable, strong medium subangular } \\
\text { blocky structure, abrupt smooth boundary, strongly effervescent, few }(3 \%) \\
0.5 \text { to } 2 \mathrm{~cm} \text { reworked rounded caliche fragments. }\end{array}$ \\
\hline 8 & $2 \mathrm{Ab}$ & -- & 4 & $\begin{array}{l}\text { Very dark grayish brown (10YR } 3 / 2) \text { loam, very friable, moderate } \\
\text { medium subangular blocky structure, diffuse smooth boundary, strongly } \\
\text { effervescent. }\end{array}$ \\
\hline 9 & $2 A B$ & -- & 4 & $\begin{array}{l}\text { Dark brown ( } 7.5 \mathrm{YR} 3 / 2 \text { to } 3 / 3) \text { loam to silty clay loam, very friable, moderate } \\
\text { to strong medium subangular blocky structure, clear smooth boundary, } \\
\text { strongly effervescent. }\end{array}$ \\
\hline 10 & $3 A k b$ & -- & 4 & $\begin{array}{l}\text { Very dark gray (10YR } 3 / 1) \text { clay to silty clay loam, friable, strong medium } \\
\text { angular blocky structure, clear smooth boundary, slightly to strongly } \\
\text { effervescent, common }(5-7 \%) \text { calcium carbonate filaments. }\end{array}$ \\
\hline 11 & $3 \mathrm{Bk}$ & -- & 4 & $\begin{array}{l}\text { Dark brown }(7.5 Y R \text { 3/2) silty clay, friable, strong medium prismatic } \\
\text { structure parting to strong medium to coarse angular blocky structure, clear } \\
\text { smooth boundary, violently effervescent, many }(7-20 \%) \text { calcium carbonate } \\
\text { filaments, common to many }(30-50 \%) \text { thin discontinuous calcium carbonate } \\
\text { coats on ped faces. }\end{array}$ \\
\hline 12 & $4 \mathrm{Abk}$ & -- & 4 & $\begin{array}{l}\text { Very dark gray (10YR } 3 / 1) \text { loam, friable to very friable, moderate to strong } \\
\text { medium to coarse angular blocky structure, diffuse smooth boundary, } \\
\text { strongly effervescent, few }(3-5 \%) \text { calcium carbonate filaments, common to } \\
\text { many }(20-50 \%) \text { thin discontinuous calcium carbonate coats on ped faces, } \\
\text { few }(1-3 \%) \text { coarse fragments. }\end{array}$ \\
\hline 13 & $5 \mathrm{C}$ & -- & $1 ?$ & $\begin{array}{l}\text { Brown (10YR 5/3) loamy sand, very friable, weak medium subangular } \\
\text { blocky structure, abrupt irregular boundary, strongly effervescent. }\end{array}$ \\
\hline 14 & $6 \mathrm{Bkm}$ & -- & Ogallala & $\begin{array}{l}\text { Pale yellow (5Y 8/3) to white (10YR 8/1) indurated caliche, extremely hard, } \\
\text { massive. }\end{array}$ \\
\hline 15 & Ap & -- & 5 & $\begin{array}{l}\text { Very dark grayish brown (10YR } 3 / 2) \text { loam, very friable, moderate medium } \\
\text { to fine subangular blocky structure, gradual smooth boundary, violently } \\
\text { effervescent. }\end{array}$ \\
\hline 16 & Bw & -- & 5 & $\begin{array}{l}\text { Brown (7.5YR 4/3) loam to silt loam, very friable, weak medium subangular } \\
\text { blocky structure, gradual smooth boundary, violently effervescent. }\end{array}$ \\
\hline 17 & C & -- & 5 & $\begin{array}{l}\text { Brown }(7.5 Y R \text { R/3) fine sand to loamy sand, loose, single grain, abrupt } \\
\text { discontinuous boundary, violently effervescent, hints of lamination in } \\
\text { places, but very fragmented bed. }\end{array}$ \\
\hline 18 & C & -- & 5 & $\begin{array}{l}\text { Brown ( } 7.5 Y R \text { Y/3) sandy loam, very friable, massive, abrupt discontinuous } \\
\text { boundary, violently effervescent, horizontally laminated. }\end{array}$ \\
\hline 19 & C & -- & 5 & $\begin{array}{l}\text { light brown }(7.5 Y R \text { R/4) very fine sand to loamy sand, very friable, single } \\
\text { grain, abrupt discontinuous boundary, violently effervescent, horizontally } \\
\text { laminated, broken bed. }\end{array}$ \\
\hline 20 & C & -- & 5 & $\begin{array}{l}\text { Brown }(7.5 Y R \text { 4/3) silt, very friable, massive, abrupt smooth boundary, } \\
\text { strongly effervescent, horizontally laminated, a bone skull fragment from } \\
\text { this zone was radiocarbon dated and yielded an age of } 3490 \pm 40 \text { years BP } \\
\text { (Beta-224050). }\end{array}$ \\
\hline
\end{tabular}




\begin{tabular}{|c|c|c|c|l|}
\hline 21 & C & -- & 5 & $\begin{array}{l}\text { Dark grayish brown (10YR 4/2) silt loam, very friable, weak medium to fine } \\
\text { subangular blocky structure, abrupt smooth boundary, few (1-3\%) calcium } \\
\text { carbonate filaments, common aquatic snails and bivalves, no obvious } \\
\text { bedding. }\end{array}$ \\
\hline 22 & C & -- & 5 & $\begin{array}{l}\text { Light yellowish brown (10YR 6/4) medium to coarse sand, loose, single } \\
\text { grain, abrupt smooth boundary, slightly effervescent, prominent cross- } \\
\text { laminated. }\end{array}$ \\
\hline 23 & C & -- & 5 & $\begin{array}{l}\text { Dark brown (10YR 3//3) to brown (10YR 4/3) loam, very friable, massive, } \\
\text { abrupt irregular boundary, strongly effervescent, horizontally laminated, } \\
\text { runoff from adjacent channel slope, few aquatic snails and clams, few 0.5-2 } \\
\text { cm rip up clasts of mud. }\end{array}$ \\
\hline 24 & C & -- & 5 & $\begin{array}{l}\text { Pale brown (10YR 6/3) medium to coarse sand, loose, single grain, abrupt } \\
\text { smooth boundary, slightly effervescent, prominent cross-laminations, a } \\
\text { bone fragment from this zone was radiocarbon dated and yielded an age } \\
\text { of 3460 } \pm 40 \text { years BP (Beta-224051). }\end{array}$ \\
\hline 25 & $5 \mathrm{C}$ & -- & 1 & $\begin{array}{l}\text { White (10YR 8/1) very fine sand to slightly gravelly to gravelly sand, loose, } \\
\text { single grain, abrupt smooth boundary, strongly effervescent, 5-50\% coarse } \\
\text { fragments. }\end{array}$ \\
\hline
\end{tabular}

\section{Gradall Trench 12}

Geologic Units: stratum 4/5m $(0-120 \mathrm{~cm})$ resting upon stratum $3(120-138 \mathrm{~cm})$, which in turn rests upon stratum $1(138-220$ $\mathrm{cm})$

Cultural material: None observed.

Comments:

\begin{tabular}{|c|c|c|c|l|}
\hline Zone & Horizon & Depth (cm) & Stratum & Description \\
\hline 1 & Ap & $0-14$ & $5-$ Apr & $\begin{array}{l}\text { Dark brown (7.5YR 3/2) sandy clay loam, firm, strong medium subangular } \\
\text { blocky structure, abrupt smooth boundary, strongly effervescent. }\end{array}$ \\
\hline 2 & A & $14-47$ & $5-$ May & $\begin{array}{l}\text { Dark brown (7.5YR 3/2) silty clay loam, very friable, weak to moderate } \\
\text { medium to fine subangular blocky structure, clear smooth boundary, } \\
\text { strongly effervescent. }\end{array}$ \\
\hline 3 & Bk1 & $47-90$ & $5-$ Apr & $\begin{array}{l}\text { Dark brown-brown (7.5YR 3.5/3) sandy loam to loam, very friable, weak } \\
\text { coarse subangular blocky structure, diffuse smooth boundary, strongly } \\
\text { effervescent, common (5-7\%) calcium carbonate filaments. }\end{array}$ \\
\hline 4 & Bk2 & $90-120$ & $5-$ Apr & $\begin{array}{l}\text { Brown (7.5YR 4/3) loam, very friable, weak medium subangular blocky } \\
\text { structure, clear smooth boundary, violently effervescent, common } \\
\text { (3-5\%) calcium carbonate filaments, few (1-2\%) matrix supported coarse } \\
\text { fragments. }\end{array}$ \\
\hline 5 & $2 \mathrm{C} 1$ & $120-138$ & 3 & $\begin{array}{l}\text { Pale brown (10YR 6/3) loam to sandy loam, very friable, massive, abrupt } \\
\text { diffuse boundary, violently effervescent, few aquatic snails. }\end{array}$ \\
\hline 6 & $3 \mathrm{C} 1$ & $138-210$ & 1 & $\begin{array}{l}\text { Light yellowish brown (10YR 6/4) sand to slightly gravelly sand, loose, } \\
\text { single grain, abrupt smooth boundary, heavily burrowed, few small rounded } \\
\text { caliche clasts, few bivalves and aquatic snails. }\end{array}$ \\
\hline 7 & $3 \mathrm{C} 2$ & $210-220$ & 1 & $\begin{array}{l}\text { White (10YR 8/1) gravelly sand, loose, single grain, slightly effervescent, } \\
\text { 30-50\% coarse fragments. }\end{array}$ \\
\hline
\end{tabular}

\section{Gradall Trench 13}

Geologic Units: Stratum 5 (group C) resting upon stratum 4/5m, which in turn rests on the Ogallala Formation caprock caliche. Cultural material: Plastic was observed in zone 17, which is modern alluvium, otherwise no cultural material was observed. 
Comments: Trench was placed into the modern floodplain margin. No depths are given as there was considerable lateral variation within this trench. Refer to the long wall drawing.

\begin{tabular}{|c|c|c|c|c|}
\hline Zone & Horizon & Depth (cm) & Stratum & Description \\
\hline 1 & Ap & -- & 5 & $\begin{array}{l}\text { Brown (10YR 4/3) loamy sand to sandy loam, friable, moderate } \\
\text { medium subangular blocky structure, abrupt smooth boundary, violently } \\
\text { effervescent. }\end{array}$ \\
\hline 2 & Bw & -- & 5 & $\begin{array}{l}\text { Dark brown (10YR 3/3) sandy loam, very friable, weak medium subangular } \\
\text { blocky structure, gradual smooth boundary, violently effervescent. }\end{array}$ \\
\hline 3 & $2 A b$ & -- & 5-Apr & $\begin{array}{l}\text { Black (10YR 2/1) loam, very friable, weak to moderate prismatic structure, } \\
\text { clear smooth boundary, slightly effervescent. }\end{array}$ \\
\hline 4 & $2 \mathrm{Bk}$ & -- & 5-Apr & $\begin{array}{l}\text { Dark brown-brown ( } 7.5 Y R \text { R } 3.5 / 2) \text { sandy clay, friable, strong medium angular } \\
\text { blocky structure, abrupt smooth boundary, violently effervescent, common } \\
(3-7 \%) \text { calcium carbonate filaments. }\end{array}$ \\
\hline 5 & $2 \mathrm{Bw}$ & -- & 5-Apr & $\begin{array}{l}\text { Brown (7.5YR 4/4) loam, very friable, weak coarse subangular blocky } \\
\text { structure, abrupt smooth boundary, strongly effervescent, few }(1-3 \%) \\
\text { calcium carbonate filaments, }<3 \% \text { coarse fragments. }\end{array}$ \\
\hline 6 & $3 \mathrm{Bkm}$ & -- & Ogallala & $\begin{array}{l}\text { White (10YR 8/1) indurated caliche, extremely hard, massive, violently } \\
\text { effervescent. }\end{array}$ \\
\hline 7 & C & -- & 5 & $\begin{array}{l}\text { Pale brown (10YR } 6 / 3 \text { ) loamy sand to sand, very friable, massive, abrupt } \\
\text { discontinuous boundary, violently effervescent. }\end{array}$ \\
\hline 8 & C & -- & 5 & $\begin{array}{l}\text { Dark grayish brown (10YR 4/2) silt loam, very friable, massive, abrupt } \\
\text { discontinuous boundary, strongly effervescent. }\end{array}$ \\
\hline 9 & C & -- & 5 & $\begin{array}{l}\text { Pale brown (10YR 6/3) fine sand to loamy sand, loose, single grain, abrupt } \\
\text { discontinuous boundary, strongly effervescent, discontinuous bed. }\end{array}$ \\
\hline 10 & C & -- & 5 & $\begin{array}{l}\text { Dark grayish brown (10YR 4/2) silt loam, very friable, weak medium } \\
\text { subangular blocky structure, abrupt smooth boundary, strongly } \\
\text { effervescent. }\end{array}$ \\
\hline 11 & C & -- & 5 & $\begin{array}{l}\text { Dark brown (7.5YR 3/2) loam, very friable, weak coarse subangular blocky } \\
\text { structure, abrupt smooth boundary, strongly effervescent. }\end{array}$ \\
\hline 12 & C & -- & 5 & $\begin{array}{l}\text { Brown (10YR 5/3) loamy sand, very friable, massive, abrupt smooth } \\
\text { boundary, strongly effervescent. }\end{array}$ \\
\hline 13 & C & -- & 5 & $\begin{array}{l}\text { Very pale brown to pale brown (10YR } 6 / 3 \text { to } 7 / 3 \text { ) sand to loamy sand, loose, } \\
\text { single grain, abrupt smooth boundary, violently effervescent, laminated. }\end{array}$ \\
\hline 14 & C & -- & 5 & $\begin{array}{l}\text { Dark gray (10YR 4/1) loam, very friable, moderate medium subangular } \\
\text { blocky structure, abrupt smooth boundary, very strongly effervescent. }\end{array}$ \\
\hline 15 & C & -- & 5 & $\begin{array}{l}\text { Very pale brown (10YR } 7 / 3) \text { sand, loose, single grain, abrupt smooth } \\
\text { boundary, strongly effervescent, many krotovina, laminated where not } \\
\text { disturbed. }\end{array}$ \\
\hline 16 & C & -- & 5 & $\begin{array}{l}\text { Brown (7.5YR 4/3) gravelly sandy clay, friable, single grain, abrupt smooth } \\
\text { boundary, strongly effervescent, } 30-45 \% \text { coarse fragments. }\end{array}$ \\
\hline 17 & C & -- & 5 & $\begin{array}{l}\text { Very dark gray (10YR } 3 / 1) \text { loam to silty clay loam, friable, moderate medium } \\
\text { subangular blocky structure, abrupt smooth boundary, slightly effervescent, } \\
\text { few }(0-3 \%) \text { coarse fragments, contains bits of plastic. }\end{array}$ \\
\hline
\end{tabular}

\section{Gradall Trench 14}

Geologic Units: stratum 4s $(0-55 \mathrm{~cm})$ resting upon stratum $3(55-105 \mathrm{~cm})$, which in turn rests on stratum 1(>105 cm).

Cultural material: None observed.

Comments: 


\begin{tabular}{|c|c|c|c|l|}
\hline Zone & Horizon & Depth (cm) & Stratum & Description \\
\hline 1 & Ap & $0-30$ & 4 & $\begin{array}{l}\text { Brown-dark brown (7.5YR 3.5/3) loam, very friable, moderate medium } \\
\text { subangular blocky structure, gradual smooth boundary, weakly } \\
\text { effervescent. }\end{array}$ \\
\hline 2 & Btk & $30-55$ & 4 & $\begin{array}{l}\text { Brown (7.5YR 4/3) loam, very friable, moderate medium subangular blocky } \\
\text { structure, abrupt smooth boundary, slightly effervescent, common (3-5\%) } \\
\text { calcium carbonate filaments. }\end{array}$ \\
\hline 3 & 2 fkb & $55-83$ & 3 & $\begin{array}{l}\text { Very dark grayish brown (10YR 3/2) loam to sandy clay, friable to very } \\
\text { friable, strong coarse to medium subangular blocky structure, clear smooth } \\
\text { boundary, violently effervescent, common (3-5\%) calcium carbonate } \\
\text { filaments, common prominent discontinuous calcium carbonate coats on } \\
\text { ped faces, few krotovina; Yellowhouse soil formed in marl. }\end{array}$ \\
\hline 4 & $2 \mathrm{C}$ & $83-105$ & 3 & $\begin{array}{l}\text { Yellowish brown (10YR 5/4) loam to sandy loam, very friable, moderate } \\
\text { medium subangular blocky structure, clear smooth boundary, violently } \\
\text { effervescent, many (10-15\%) calcium carbonate filaments, many krotovinas; } \\
\text { marl. }\end{array}$ \\
\hline 5 & $3 \mathrm{C}$ & $105-150$ & 1 & $\begin{array}{l}\text { Very pale brown (10YR 7/3) loamy sand, very friable, weak medium } \\
\text { subangular blocky structure, slightly effervescent, many krotovinas. }\end{array}$ \\
\hline
\end{tabular}

\section{Gradall Trench 15}

Geologic Units: Fill over Stratum 4/5

Cultural material: --

Comments: Trench was excavated to $2 \mathrm{~m}$ depth, and all but the last $35 \mathrm{~cm}$ was fill. Basal $35 \mathrm{~cm}$ was probably stratum $4 / 5$ (brown (7.5YR 4/4) loam to sandy loam, very friable, moderate medium subangular blocky structure, strongly calcareous).

\section{Gradall Trench 16}

Geologic Units: recent fill $(0-45 \mathrm{~cm})$ resting upon stratum 4/5 $(45-200 \mathrm{~cm})$

Cultural material: Only observed in the recent fill.

Comments:

\begin{tabular}{|c|c|c|c|l|}
\hline Zone & Horizon & Depth (cm) & Stratum & Description \\
\hline 1 & C & $0-30$ & Fill & Not described. \\
\hline 2 & C & $30-40$ & Fill & Not described. \\
\hline 3 & C & $40-45$ & Fill & Not described. \\
\hline 4 & $2 \mathrm{Ab}$ & $45-70$ & $5-\mathrm{Apr}$ & $\begin{array}{l}\text { Dark brown (7.5YR 3/2) loam to sandy loam, very friable, weak to medium } \\
\text { moderate subangular blocky structure, gradual smooth boundary, strongly } \\
\text { effervescent. }\end{array}$ \\
\hline 5 & $2 \mathrm{Bt}$ & $70-120$ & $5-\mathrm{Apr}$ & $\begin{array}{l}\text { Brown (7.5YR 4/4) sandy clay, friable, weak to moderate medium angular } \\
\text { blocky structure, diffuse, irregular boundary, violently effervescent, common } \\
\text { (3-5\%) calcium carbonate filaments. }\end{array}$ \\
\hline 6 & $2 \mathrm{BC}$ & $120-175$ & $5-\mathrm{Apr}$ & $\begin{array}{l}\text { Brown (10YR 5/3) loamy sand, friable, weak medium to coarse subangular } \\
\text { blocky structure, clear smooth boundary, strongly effervescent, many } \\
\text { krotovina. }\end{array}$ \\
\hline 7 & 2C & $175-190$ & 5-Apr & $\begin{array}{l}\text { Grayish brown (2.5Y 5/2) very fine sand to loamy sand, very friable, } \\
\text { moderate fine subangular blocky structure, abrupt smooth boundary, } \\
\text { strongly effervescent, probably has calcium carbonate filaments but none } \\
\text { visible in the moist state. }\end{array}$ \\
\hline
\end{tabular}




\begin{tabular}{|c|c|c|c|l|l|}
\hline 8 & 2C & $190-200$ & 5-Apr & $\begin{array}{l}\text { White (10YR 8/1) sand, loose, single grain, slightly effervescent, } \\
\text { laminated. }\end{array}$ \\
\hline
\end{tabular}

\section{Gradall Trench 17}

Geologic Units: stratum $5 \mathrm{~m}(0-73 \mathrm{~cm}$, resting upon stratum $4(73-157 \mathrm{~cm})$, resting upon stratum $3(157-180 \mathrm{~cm})$.

Cultural material: None observed

Comments:

\begin{tabular}{|c|c|c|c|l|}
\hline Zone & Horizon & Depth (cm) & Stratum & Description \\
\hline 1 & Ap & $0-31$ & 5 & $\begin{array}{l}\text { Black (10YR 2/1) silty clay loam, friable, moderate medium subangular } \\
\text { blocky structure parting to moderate fine granular structure, clear smooth } \\
\text { boundary, slightly effervescent. }\end{array}$ \\
\hline 2 & AB & $31-73$ & 5 & $\begin{array}{l}\text { Very dark gray (10YR 3/2) clay to silty clay loam, friable, strong } \\
\text { medium subangular blocky structure, clear smooth boundary, strongly } \\
\text { effervescent. }\end{array}$ \\
\hline 3 & 2 Akb & $73-93$ & 4 & $\begin{array}{l}\text { Very dark brown (10YR 2/2) silty clay loam, friable, moderate to strong } \\
\text { fine prismatic structure, clear smooth boundary, strongly effervescent, few } \\
(1-3 \%) \text { calcium carbonate filaments. }\end{array}$ \\
\hline 4 & $2 B w 1$ & $93-125$ & 4 & $\begin{array}{l}\text { Brown (7.5YR 4/3) loam, friable, strong coarse subangular blocky structure, } \\
\text { gradual smooth boundary, strongly effervescent, common (5-7\%) calcium } \\
\text { carbonate filaments, common dark brown (7.5YR 3/2) clay (?) coats on ped } \\
\text { faces, few thin patchy calcium carbonate coats on ped faces. }\end{array}$ \\
\hline 5 & $2 B w 2$ & $125-157$ & 4 & $\begin{array}{l}\text { Brown (7.5YR 5/3) sandy loam, very friable, weak to moderate medium } \\
\text { subangular blocky structure, abrupt irregular boundary, strongly } \\
\text { effervescent, many krotovina. }\end{array}$ \\
\hline 6 & $3 \mathrm{C}$ & $157-180$ & 3 & $\begin{array}{l}\text { Light brownish gray (10YR 6/2) sandy loam to loamy sand, very friable, } \\
\text { weak coarse subangular blocky structure, violently effervescent, abundant } \\
\text { diffuse calcium carbonate, many krotovina; marl. }\end{array}$ \\
\hline
\end{tabular}

\section{Gradall Trench 18}

Geologic Units: stratum $5 \mathrm{~m}(0-72 \mathrm{~cm})$ resting upon stratum $4 \mathrm{~m}(72-170 \mathrm{~cm})$, which in turn rests upon stratum $3(170-180+$ $\mathrm{cm})$.

Cultural material: None observed.

Comments:

\begin{tabular}{|c|c|c|c|l|}
\hline Zone & Horizon & Depth (cm) & Stratum & Description \\
\hline 1 & Ap & $0-21$ & 5 & $\begin{array}{l}\text { Very dark brown (7.5YR 2.5/2) silty clay loam, firm, moderate to strong } \\
\text { coarse angular blocky structure, abrupt smooth boundary, strongly } \\
\text { effervescent, possibly compacted by machinery. }\end{array}$ \\
\hline 2 & A & $21-47$ & 5 & $\begin{array}{l}\text { Very dark brown (7.5YR 2.5/2) silty clay loam, friable, moderate to strong } \\
\text { medium subangular blocky structure, clear smooth boundary, strongly } \\
\text { effervescent. }\end{array}$ \\
\hline 3 & AB & $47-72$ & 5 & $\begin{array}{l}\text { Dark brown (7.5YR 3/2) silty clay loam, friable, weak to moderate fine } \\
\text { prismatic structure, abrupt smooth boundary, very strongly effervescent. }\end{array}$ \\
\hline 4 & $2 \mathrm{Ab}$ & $72-100$ & 4 & $\begin{array}{l}\text { Very dark brown (7.5YR 2.5/2) clay, firm, strong medium subangular blocky } \\
\text { structure, abrupt irregular boundary, strongly effervescent. }\end{array}$ \\
\hline
\end{tabular}




\begin{tabular}{|c|c|c|c|l|}
\hline 5 & 2Bw & $100-145$ & 4 & $\begin{array}{l}\text { Dark brown (7.5YR 3/3) loam, friable, moderate medium prismatic structure, } \\
\text { gradual smooth boundary, very strongly effervescent, few (1-3\%) calcium } \\
\text { carbonate filaments, few very dark grayish brown (10YR 3/2) clay (?) coats } \\
\text { on ped faces. }\end{array}$ \\
\hline 6 & 2C & $145-170$ & 4 & $\begin{array}{l}\text { Brown (7.5YR 4/4) sandy loam, very friable, weak coarse subangular } \\
\text { blocky structure, clear smooth boundary, very strongly effervescent. }\end{array}$ \\
\hline 7 & 3C & $170-180$ & 3 & $\begin{array}{l}\text { Light gray (10YR 7/2) sandy loam, very friable, weak medium subangular } \\
\text { blocky structure, violently effervescent, marl. }\end{array}$ \\
\hline
\end{tabular}

\section{Gradall Trench 19}

Geologic Units: Stratum 4/5m $(0-130 \mathrm{~cm})$ resting upon stratum $3(130-160 \mathrm{~cm})$, which in turn rests upon stratum $1(160-200$ $\mathrm{cm})$

Cultural material: None observed.

Comments:

\begin{tabular}{|c|c|c|c|l|}
\hline Zone & Horizon & Depth (cm) & Stratum & Description \\
\hline 1 & Ap & $0-20$ & 5 -Apr & $\begin{array}{l}\text { Dark brown (7.5YR 3/2) sandy clay, friable, moderate to strong medium } \\
\text { angular blocky structure, abrupt smooth boundary, strongly effervescent. }\end{array}$ \\
\hline 2 & A & $20-60$ & 5-Apr & $\begin{array}{l}\text { Very dark brown (10YR 2/2) silty clay loam, friable, moderate to strong fine } \\
\text { to medium subangular blocky structure, gradual smooth boundary, strongly } \\
\text { effervescent. }\end{array}$ \\
\hline 3 & Bw1 & $60-110$ & 5-Apr & $\begin{array}{l}\text { Brown (7.5YR 4/3) loam, very friable, weak to moderate medium subangular } \\
\text { blocky structure, gradual smooth boundary, strongly effervescent, few (1\%) } \\
\text { rounded caliche coarse fragments. }\end{array}$ \\
\hline 4 & Bw2 & $110-130$ & $5-A p r$ & $\begin{array}{l}\text { Pink (7.5YR 7/3) sandy loam, very friable, moderate fine subangular blocky } \\
\text { structure, clear smooth boundary, strongly effervescent. }\end{array}$ \\
\hline 5 & 2C & $130-145$ & 3 & $\begin{array}{l}\text { Very pale brown (10YR 8/2) sandy loam, very friable, moderate medium } \\
\text { subangular blocky structure, abrupt discontinuous boundary, violently } \\
\text { effervescent, many krotovina; marl. }\end{array}$ \\
\hline 6 & 2C & $145-160$ & 3 & $\begin{array}{l}\text { Light gray (10YR 7/2) sandy loam to loam, firm, strong fine subangular } \\
\text { blocky structure, abrupt smooth boundary, violently effervescent, abundant } \\
\text { diffuse calcium carbonate; marl. }\end{array}$ \\
\hline 7 & 3C & $160-185$ & 1 & $\begin{array}{l}\text { pale brown (10YR 6/3) slightly gravelly sand to loamy sand, very friable, } \\
\text { single grain, abrupt smooth boundary, strongly effervescent, many } \\
\text { krotovina, few (3\%) coarse fragments. }\end{array}$ \\
\hline 8 & 3C & $185-200$ & 1 & $\begin{array}{l}\text { Light yellowish brown (2.5Y 6/3) loamy sand, very friable, weak medium } \\
\text { subangular blocky structure, slightly effervescent, common krotovina. }\end{array}$ \\
\hline
\end{tabular}

\section{Gradall Trench 20}

Geologic Units: Fill over Strata 4, 3, and 1

Cultural material: None observed.

Comments: This description was presented in the report text and is not repeated here.

\section{Gradall Trench 21}

Geologic Units: stratum 4/5m $(0-80 \mathrm{~cm})$, resting upon the Yellowhouse soil and Stratum 3(80-200 cm) which in turn rests upon stratum $1(200-215 \mathrm{~cm})$. Ogallala Formation was exposed beneath stratum 1.

Cultural material: None observed.

Comments: No depths are listed as there was lateral variation within the trench. Refer to the long wall drawing for the relative stratigraphic position of each zone. 


\begin{tabular}{|c|c|c|c|c|}
\hline Zone & Horizon & Depth $(\mathrm{cm})$ & Stratum & Description \\
\hline 1 & Ap & -- & colluvium & Slope wash, not described in detail. \\
\hline 2 & A & -- & $4 / 5 \mathrm{~m}$ & $\begin{array}{l}\text { Very dark grayish brown (10YR } 3 / 2) \text { silty clay, firm, strong medium to } \\
\text { fine subangular blocky structure, gradual smooth boundary, strongly } \\
\text { effervescent. }\end{array}$ \\
\hline 3 & Bw & -- & $4 / 5 \mathrm{~m}$ & $\begin{array}{l}\text { Brown (7.5YR 4/3) silty clay loam, firm, strong fine angular blocky structure, } \\
\text { clear smooth boundary, strongly effervescent. }\end{array}$ \\
\hline 4 & $\mathrm{Bk}$ & -- & $4 / 5 \mathrm{~m}$ & $\begin{array}{l}\text { Brown ( } 7.5 \text { YR } 4 / 2) \text { clay, firm, strong fine prismatic structure, abrupt smooth } \\
\text { boundary, violently effervescent, common ( } 3-5 \%) \text { calcium carbonate } \\
\text { filaments, few thin discontinuous carbonate coats on ped faces. }\end{array}$ \\
\hline 5 & C & -- & $4 / 5 \mathrm{~m}$ & $\begin{array}{l}\text { Brown-strong brown }(7.5 Y R \text { R/5) loam to loamy sand, very friable, weak } \\
\text { coarse subangular blocky structure, abrupt smooth boundary, strongly } \\
\text { effervescent, few (1-3\%) calcium carbonate filaments. }\end{array}$ \\
\hline 6 & $2 \mathrm{Akb}$ & -- & 3 & $\begin{array}{l}\text { Brown ( } 7.5 \text { YR } 4 / 3) \text { loam, firm to friable, strong medium subangular blocky } \\
\text { structure, clear smooth boundary, violently effervescent, common (5-10\%) } \\
\text { calcium carbonate filaments, few thin discontinuous carbonate coats on } \\
\text { ped faces. }\end{array}$ \\
\hline 7 & $2 \mathrm{Bk}$ & -- & 3 & $\begin{array}{l}\text { Brown (7.5YR 5/4)loam, very friable, weak coarse subangular blocky } \\
\text { structure, diffuse smooth boundary, strongly effervescent, common }(5-7 \%) \\
\text { calcium carbonate filaments, few (1-3\%) } 0.5-3 \mathrm{~cm} \text { diffusely scattered matrix } \\
\text { supported gravels of reworked caliche. }\end{array}$ \\
\hline 8 & $2 \mathrm{Bk}$ & -- & 3 & $\begin{array}{l}\text { Light yellowish brown (10YR 6/4) loamy sand, very friable, weak coarse } \\
\text { subangular blocky structure, abrupt discontinuous boundary, strongly } \\
\text { effervescent, common (5-7\%) calcium carbonate filaments, few (1-3\%) } \\
0.5-3 \mathrm{~cm} \text { diffusely scattered matrix supported gravels of reworked caliche. }\end{array}$ \\
\hline 9 & $2 \mathrm{C}$ & -- & 3 & $\begin{array}{l}\text { Light brownish gray ( } 102.5 \mathrm{Y} 6 / 2) \text { sandy loam to loamy sand, very friable, } \\
\text { weak medium subangular blocky structure, abrupt discontinuous boundary, } \\
\text { violently effervescent, common aquatic snails, small fragment isolated by } \\
\text { bioturbation. }\end{array}$ \\
\hline 10 & $2 \mathrm{C}$ & -- & 3 & $\begin{array}{l}\text { White (10YR } 8 / 1) \text { medium to coarse sand, loose, single grain, abrupt } \\
\text { smooth boundary, strongly effervescent, laminated, contains small snails } \\
\text { and bivalves. }\end{array}$ \\
\hline 11 & $2 \mathrm{C}$ & -- & 3 & $\begin{array}{l}\text { Grayish brown }(2.5 \mathrm{Y} 5 / 2) \text { sandy loam, friable, weak fine to medium } \\
\text { subangular blocky structure, abrupt discontinuous boundary, violently } \\
\text { effervescent, common }(5-7 \% \text { calcium carbonate filaments. }\end{array}$ \\
\hline 12 & $3 C$ & -- & 1 & $\begin{array}{l}\text { Very pale brown (10YR } 7 / 3) \text { gravelly sand, loose, single grain, abrupt } \\
\text { irregular boundary, slightly effervescent, very poorly sorted, many } \\
\text { krotovina. }\end{array}$ \\
\hline
\end{tabular}

